Nevada

Environmental

Restoration

Project

\title{
Closure Report for Corrective Action Unit 134: Aboveground Storage Tanks, Nevada Test Site, Nevada
}

Controlled Copy No.:

Revision: 0

June 2009

Environmental Restoration

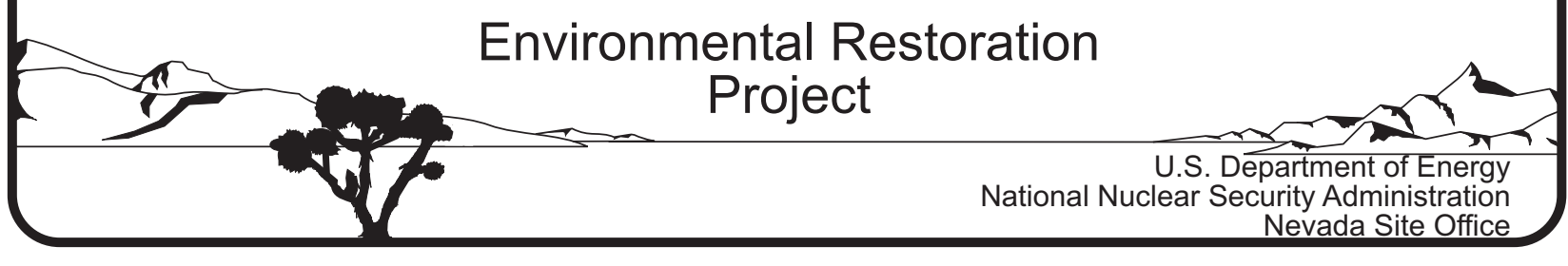




\section{DISCLAIMER}

Reference herein to any specific commercial product, process, or service by trade name, trademark, manufacturer, or otherwise, does not necessarily constitute or imply its endorsement, recommendation, or favoring by the United States Government or any agency thereof.

This report has been reproduced directly from the best available copy.

Available for sale to the public from:

U.S. Department of Commerce

National Technical Information Service

5285 Port Royal Road

Springfield, VA 22161-0002

Telephone: (800) 553-6847

Fax: (703) 605-6900

E-mail: orders@ntis.gov

Online ordering: http://www.ntis.gov/ordering.htm

Available electronically at http://www.osti.gov/bridge.

Available for a processing fee to the U.S. Department of Energy and its contractors, in paper, from:

U.S. Department of Energy

Office of Scientific and Technical Information

P.O. Box 62

Oak Ridge, TN 37831-0062

Telephone: (865) 576-8401

Fax: (865) 576-5728

E-mail: reports@adonis.osti.gov 


\title{
CLOSURE REPORT FOR CORRECTIVE ACTION UNIT 134: ABOVEGROUND STORAGE TANKS, NEVADA TEST SITE, NEVADA
}

\author{
U.S. Department of Energy \\ National Nuclear Security Administration \\ Nevada Site Office \\ Las Vegas, Nevada
}

Controlled Copy No.

Revision: 0

June 2009 
THIS PAGE INTENTIONALLY LEFT BLANK 


\section{CLOSURE REPORT FOR CORRECTIVE ACTION UNIT 134: ABOVEGROUND STORAGE TANKS, NEVADA TEST SITE, NEVADA}

$\begin{array}{rlr}\text { Approved By: } & \frac{/ \mathrm{s} / \text { Kevin J. Cabble }}{\text { Kevin J. Cabble, }} \quad \text { Date: } 6 / 15 / 2009 \\ & \text { Federal Sub-Project Director } \\ \text { Industrial Sites Sub-Project } & \end{array}$

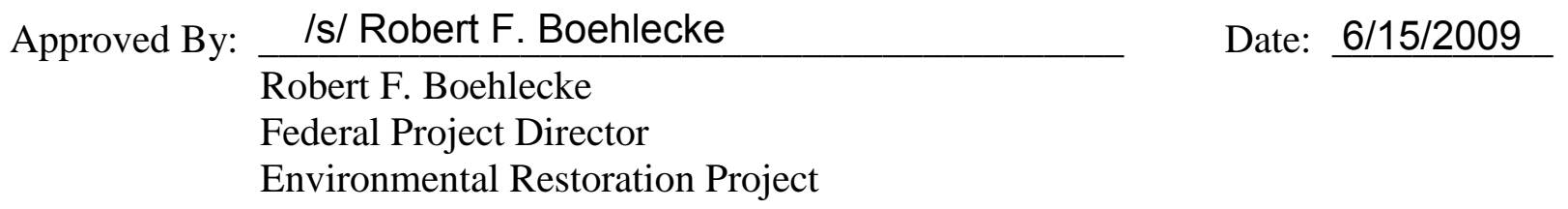


THIS PAGE INTENTIONALLY LEFT BLANK 


\section{TABLE OF CONTENTS}

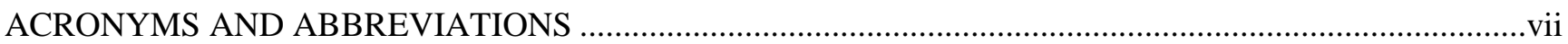

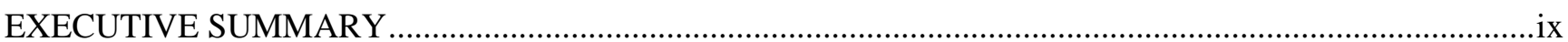

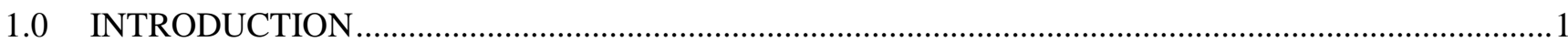

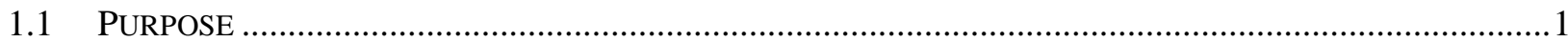

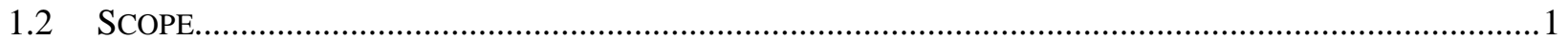

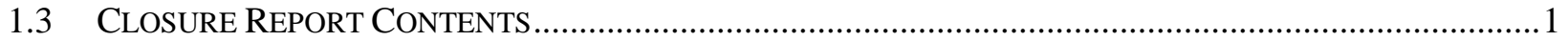

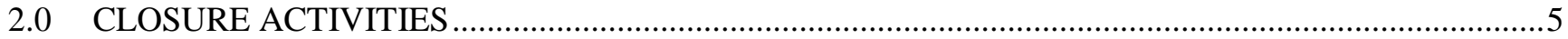

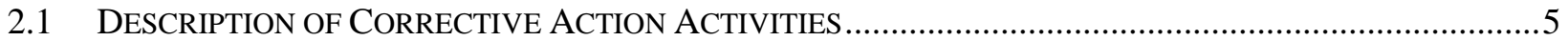

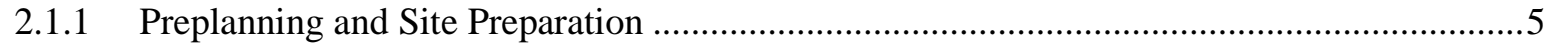

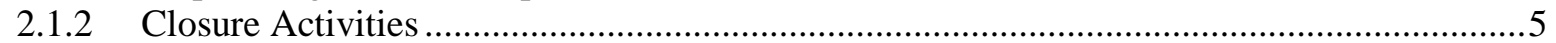

2.1.2.1 Corrective Action Site 03-01-03, Aboveground Storage Tank ............................... 5

2.1.2.2 Corrective Action Site 03-01-04, Tank.................................................................

2.1.2.3 Corrective Action Site 15-01-05, Aboveground Storage Tank ................................

2.1.2.4 Corrective Action Site 29-01-01, Hydrocarbon Stain ..............................................8

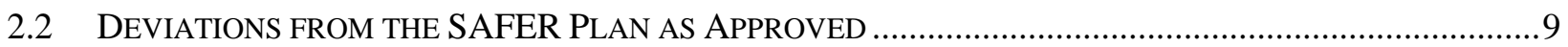

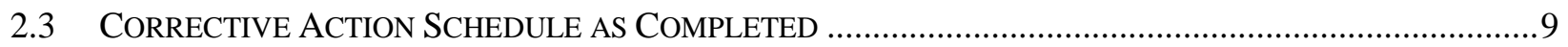

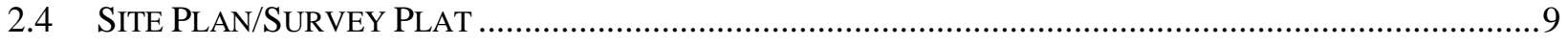

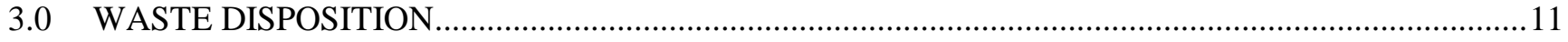

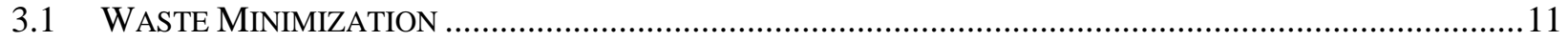

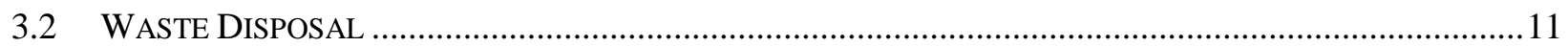

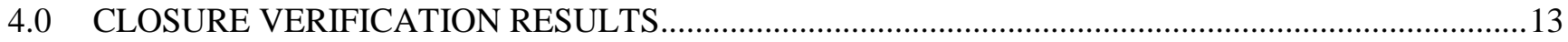

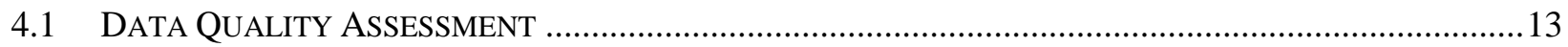

4.1.1 Quality Assurance and Quality Control Procedures .....................................................13

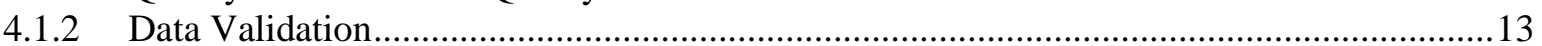

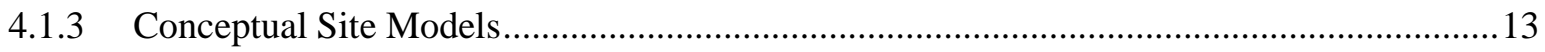

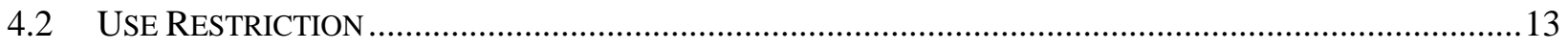

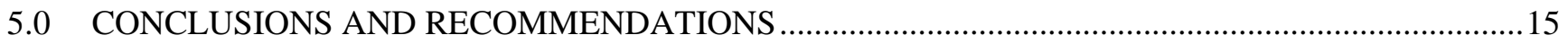

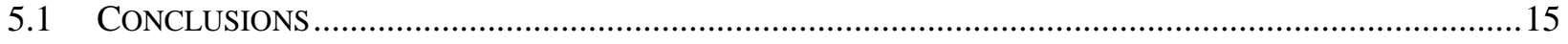

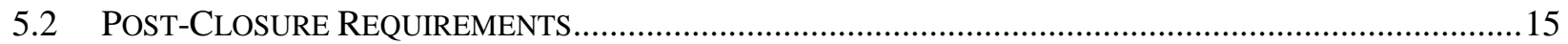

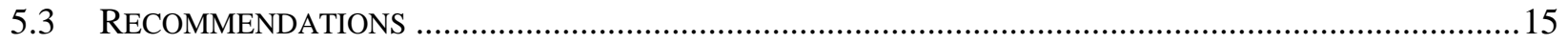

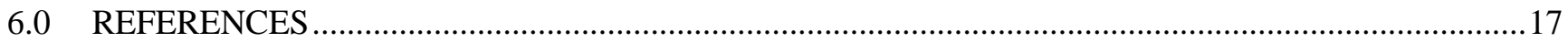

LIBRARY DISTRIBUTION LIST

\section{LIST OF FIGURES}

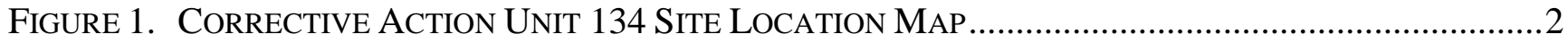

Figure 2. Corrective Action Site 15-01-05, AbOveground StORAGE TANK ...............................6 


\section{LIST OF TABLES}

TABle 1. Summary of Corrective Action Unit 134 Closure Activities ................................... IX

TABle 2. Analytical Results for Corrective Action Site 15-01-05 ..........................................7

TABle 3. AnAlytical Results For CorRective ACtion Site 29-01-01 ........................................8

Table 4. Corrective Action Unit 134 Closure Activities Schedule .......................................9

\section{APPENDICES}

Appendix A. DATa Quality ObJectives

APPENDiX B. SAMPLE ANALYTICAL RESUltS

APPENDIX C. WASTE DISPOSITION DOCUMENTATION

APPENDIX D. Site ClOSURE PHOTOGRAPHS

AppendiX E. MEMORANDUM OF Historical SignifiCANCE of TANK AT CORRECTIVE ACTION Site 15-01-05

ApPENDiX F. NEVADA Division of ENVIRONMENTAL PROTECTION COMMENT RESPONSE FoRM 


\section{ACRONYMS AND ABBREVIATIONS}

BMP best management practice

CAS Corrective Action Site

CAU Corrective Action Unit

COC contaminant of concern

CR Closure Report

CSM conceptual site model

EPA U.S. Environmental Protection Agency

FFACO Federal Facility Agreement and Consent Order

$\mathrm{J} \quad$ estimated value

$\mathrm{mg} / \mathrm{kg} \quad$ milligram(s) per kilogram

NA not analyzed for in sample

NDEP Nevada Division of Environmental Protection

NNSA/NSO U.S. Department of Energy, National Nuclear Security Administration Nevada Site Office

NNSA/NV U.S. Department of Energy, National Nuclear Security Administration Nevada Operations Office

NTS Nevada Test Site

QA quality assurance

QAPP Industrial Sites Quality Assurance Project Plan

QC quality control

SAFER Streamlined Approach for Environmental Restoration

TPH total petroleum hydrocarbons 
CAU 134 Closure Report

Section: Acronyms

Revision: 0

Date: June 2009

\section{THIS PAGE INTENTIONALLY LEFT BLANK}




\section{EXECUTIVE SUMMARY}

Corrective Action Unit (CAU) 134 is identified in the Federal Facility Agreement and Consent Order (FFACO) as "Aboveground Storage Tanks" and consists of the following four Corrective Action Sites (CASs), located in Areas 3, 15, and 29 of the Nevada Test Site:

- CAS 03-01-03, Aboveground Storage Tank

- CAS 03-01-04, Tank

- CAS 15-01-05, Aboveground Storage Tank

- CAS 29-01-01, Hydrocarbon Stain

Closure activities were conducted from October 2008 to December 2008 according to the FFACO (1996; as amended February 2008), the Streamlined Approach for Environmental Restoration (SAFER) Plan for CAU 134 (U.S. Department of Energy, National Nuclear Security Administration Nevada Site Office [NNSA/NSO], 2008a), and the Addendum to the SAFER Plan for CAU 134 (NNSA/NSO, 2008b). All CASs were closed by taking No Further Action. Closure activities are summarized in Table 1.

TABle 1. Summary of Corrective ACtion Unit 134 Closure ACtivities

\begin{tabular}{|c|c|c|c|c|}
\hline CAS & CAS NAME & $\begin{array}{l}\text { CLOSURE } \\
\text { METHOD }\end{array}$ & $\mathrm{COC}$ & Closure ACtivities \\
\hline $03-01-03$ & $\begin{array}{l}\text { Aboveground } \\
\text { Storage Tank }\end{array}$ & $\begin{array}{l}\text { No Further } \\
\text { Action }\end{array}$ & None & $\begin{array}{l}\text { As a BMP, the tank was removed and disposed as } \\
\text { sanitary waste. }\end{array}$ \\
\hline 03-01-04 & Tank & $\begin{array}{l}\text { No Further } \\
\text { Action }\end{array}$ & None & None \\
\hline $15-01-05$ & $\begin{array}{l}\text { Aboveground } \\
\text { Storage Tank }\end{array}$ & $\begin{array}{l}\text { No Further } \\
\text { Action }\end{array}$ & None & $\begin{array}{l}\text { Corrective action investigation samples were } \\
\text { collected to confirm COCs were not present above } \\
\text { action levels. }\end{array}$ \\
\hline 29-01-01 & $\begin{array}{l}\text { Hydrocarbon } \\
\text { Stain }\end{array}$ & $\begin{array}{l}\text { No Further } \\
\text { Action }\end{array}$ & None & $\begin{array}{l}\text { Corrective action investigation samples were } \\
\text { collected to confirm COCs were not present above } \\
\text { action levels. }\end{array}$ \\
\hline
\end{tabular}

BMP: best management practice

CAS: Corrective Action Site

COC: contaminant of concern 
CAU 134 Closure Report

Section: Executive Summary

Revision: 0

Date: June 2009

THIS PAGE INTENTIONALLY LEFT BLANK 


\subsection{INTRODUCTION}

This Closure Report (CR) documents closure activities for Corrective Action Unit (CAU) 134, “Aboveground Storage Tanks," according to the Federal Facility Agreement and Consent Order (FFACO) (1996; as amended February 2008), the Streamlined Approach for Environmental Restoration (SAFER) Plan for CAU 134 (U.S. Department of Energy, National Nuclear Security Administration Nevada Site Office [NNSA/NSO], 2008a), and the Addendum to the SAFER Plan for CAU 134 (NNSA/NSO, 2008b). CAU 134 consists of the following four Corrective Action Sites (CASs), located in Areas 3, 15, and 29 of the Nevada Test Site (NTS) (Figure 1):

- CAS 03-01-03, Aboveground Storage Tank

- CAS 03-01-04, Tank

- CAS 15-01-05, Aboveground Storage Tank

- CAS 29-01-01, Hydrocarbon Stain

\subsection{PuRpose}

CAU 134, “Aboveground Storage Tanks,” consists of four CASs in Areas 3, 15, and 29 of the NTS. All CASs were closed by taking No Further Action. This CR provides a summary of closure activities, documentation of waste disposal, and confirmation that remediation goals were met.

\subsection{SCOPE}

The closure strategy for CAU 134 included the following activities:

- At CAS 03-01-03, Aboveground Storage Tank, no further action was required. However, as a best management practice (BMP), the tank was removed for disposal as sanitary waste.

- At CAS 03-01-04, Tank, no further action was required, and no work was performed.

- At CAS 15-01-05, Aboveground Storage Tank, samples were collected to confirm that contaminants of concern (COCs) are not present above action levels. No further action was required.

- At CAS 29-01-01, Hydrocarbon Stain, samples were collected to confirm that COCs are not present above action levels. No further action was required.

\subsection{Closure Report Contents}

This CR includes the following sections:

- Section 1.0 - Introduction

- Section 2.0 - Closure Activities

- Section 3.0 - Waste Disposition

- Section 4.0 - Closure Verification Results

- Section 5.0 - Conclusions and Recommendations

- Section 6.0 - References 


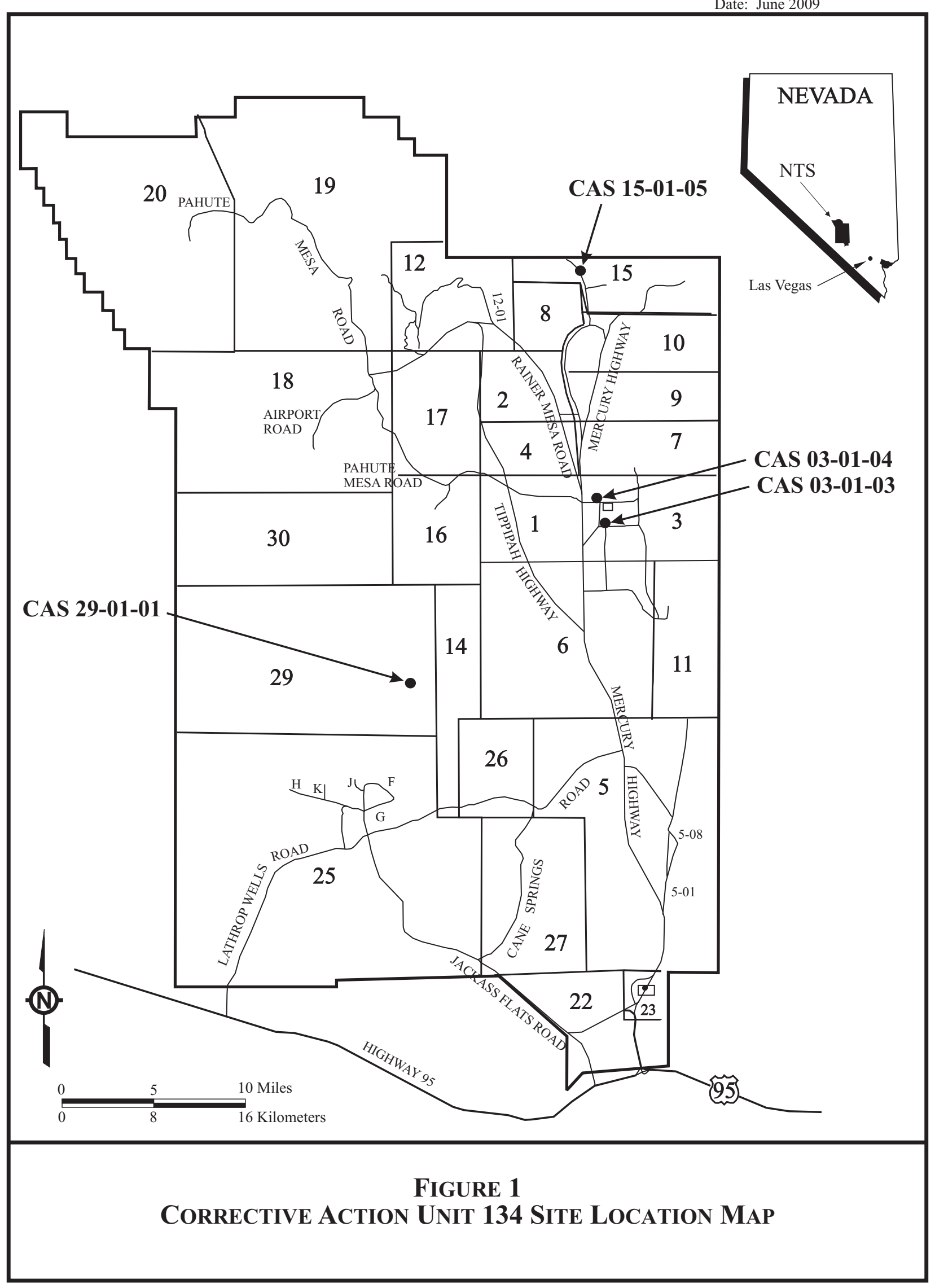


- Appendix A - Data Quality Objectives

- Appendix B - Sample Analytical Results

- Appendix C - Waste Disposition Documentation

- Appendix D - Site Closure Photographs

- Appendix E - Memorandum of Historical Significance of Tank at Corrective Action Site 15-01-05

- Appendix F - Nevada Division of Environmental Protection Comment Response Form

- Library Distribution List

This report was developed using information and guidance from the following documents:

- $\quad$ SAFER Plan for CAU 134 (NNSA/NSO, 2008a)

- Addendum to the SAFER Plan for CAU 134 (NNSA/NSO, 2008b)

- Industrial Sites Quality Assurance Project Plan (QAPP) (U.S. Department of Energy, National Nuclear Security Administration Nevada Operations Office [NNSA/NV], 2002)

Data quality objectives developed for site characterization of CAU 134 were presented in Section 3.0 of the SAFER Plan for CAU 134 (NNSA/NSO, 2008a) and are included as Appendix A of this report. Conceptual site models (CSMs) were developed based on process knowledge, historical information, and personnel interviews. No variations to the CSMs were identified, and the CSMs were confirmed by soil sample results and verified during closure activities. 
CAU 134 Closure Report

Section: Introduction

Revision: 0

Date: June 2009

THIS PAGE INTENTIONALLY LEFT BLANK 


\subsection{CLOSURE ACTIVITIES}

This section describes the closure activities completed for CAU 134, deviations from the SAFER Plan, and the schedule of completed activities.

\subsection{Description of Corrective Action Activities}

The following sections describe the closure activities completed for CAU 134 .

\subsubsection{Preplanning and Site Preparation}

Prior to closure activities, the following documents were prepared:

- National Environmental Policy Act Checklist

- Site-Specific Health and Safety Plan

- Field Management Plan

- NNSA/NSO Real Estate/Operations Permit

- Work control packages

\subsubsection{Closure Activities}

The following sections detail the closure activities completed at each CAS.

\subsubsection{Corrective Action Site 03-01-03, Aboveground Storage Tank}

This site consisted of a tank designed for storage of drilling mud. No COCs are present; therefore, the site was closed by taking no further action. As a BMP, the tank was removed and disposed as sanitary waste at the Area 9 U10c Sanitary Landfill after being verified empty and screened for free-release per the NV/YMP Radiological Control Manual (NNSA/NSO, 2004).

\subsubsection{Corrective Action Site 03-01-04, Tank}

This site consists of a 20,000-gallon tank formally used to store potable water. No COCs are present; therefore, the site was closed by taking no further action. No work was performed.

\subsubsection{Corrective Action Site 15-01-05, Aboveground Storage Tank}

This site consists of a tank and soil potentially impacted by the tank. Soil samples were collected from the tank's current location and most likely original location. The sample locations are shown in Figure 2. Samples were analyzed for total petroleum hydrocarbons (TPH) using U.S. Environmental Protection Agency (EPA) Method 8015B and for the hazardous constituents of TPH using EPA Methods 8260 and 8270 . Analytical results are summarized in Table 2. Samples collected from the tank's original location contained TPH at concentrations greater than the action level of 100 milligrams per kilogram (mg/kg); however, the hazardous constituents of TPH did not exceed the action levels. Therefore, TPH was not considered a COC, and no further action was required. Because the tank was determined to be a cultural resource of historic value, the tank was left in place. A memorandum stating the historical significance of the tank and recommendation to leave the tank in place is included as Appendix E. 


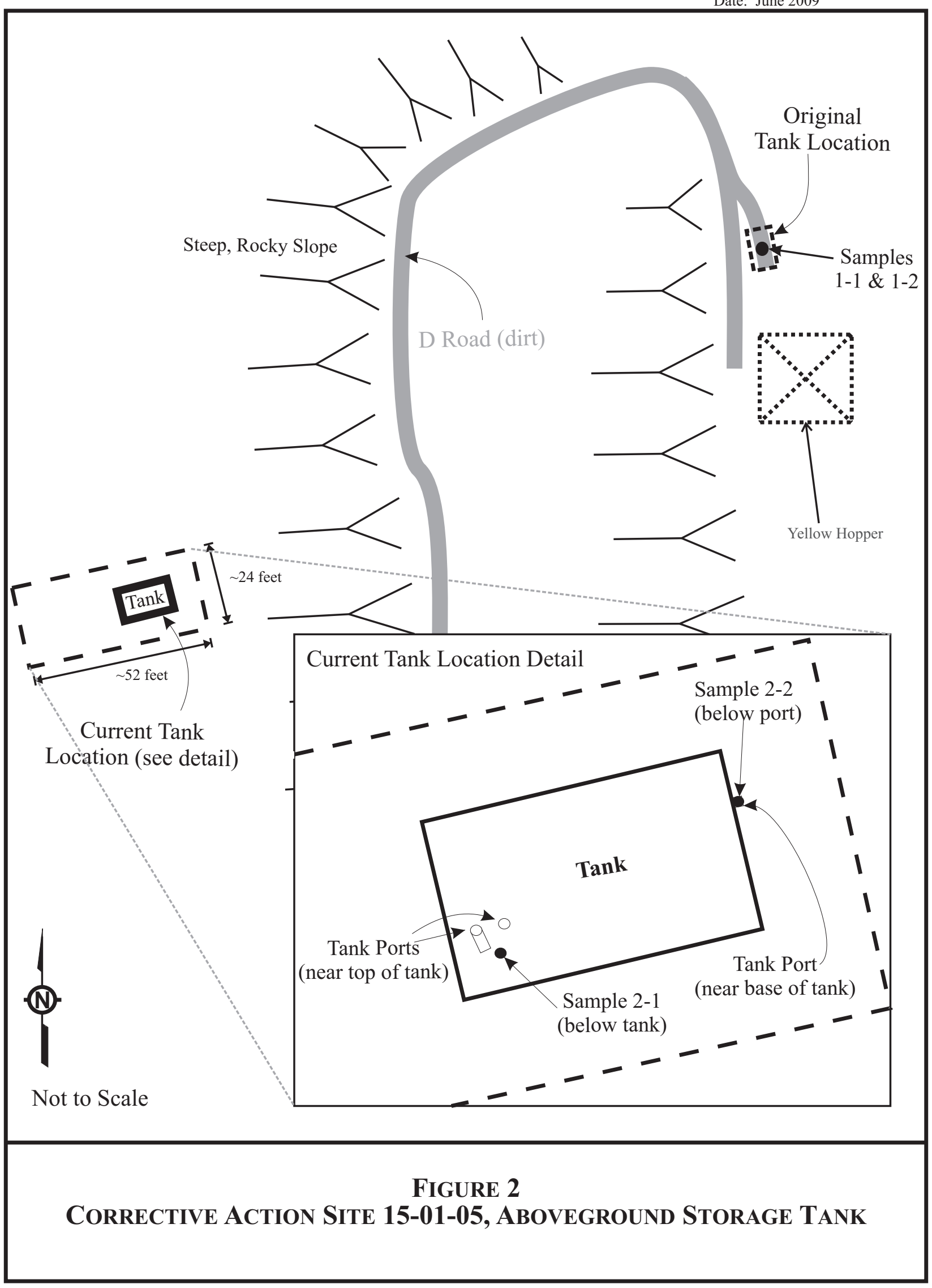


TAble 2. AnAlytical Results for Corrective ACtion Site 15-01-05

\begin{tabular}{|c|c|c|c|c|c|c|}
\hline \multirow{3}{*}{$\mid$} & \multirow{3}{*}{ ANALYTE } & \multirow{3}{*}{$\begin{array}{c}\text { ACTION } \\
\text { LEVEL } \\
\text { (mg/kg) }\end{array}$} & \multicolumn{4}{|c|}{ SAMPLE RESULTS (mg/kg) } \\
\hline & & & \multicolumn{2}{|c|}{$\begin{array}{c}\text { ORIGINAL TANK } \\
\text { LOCATION SAMPLES }\end{array}$} & \multicolumn{2}{|c|}{$\begin{array}{c}\text { CURRENT TANK } \\
\text { LOCATION SAMPLES }\end{array}$} \\
\hline & & & 1-1 & $1-2$ & $2-1$ & $2-2$ \\
\hline \multirow{4}{*}{$\begin{array}{l}\text { Petroleum } \\
\text { Hydrocarbons }\end{array}$} & Gasoline & - & $<23$ & $<23$ & $<24$ & $<23$ \\
\hline & Diesel & - & $<68.2$ & $<68.1$ & $<3.5$ & $<3.42$ \\
\hline & Motor Oil & - & 2,800 & 3,000 & 58 & 33 \\
\hline & TPH & 100 & 2,800 & 3,000 & 58 & 33 \\
\hline \multirow{20}{*}{$\begin{array}{l}\text { Hazardous } \\
\text { Constituents } \\
\text { of TPH }\end{array}$} & 1,3,5-Trimethylbenzene & 70 & $<0.6$ & NA & $<0.66$ & $<0.63$ \\
\hline & 2-Methylnaphthalene & 190 & $<1.7$ & NA & $<0.35$ & $<0.34$ \\
\hline & Anthracene & 100,000 & $<1.7$ & NA & $<0.35$ & $<0.34$ \\
\hline & Benzo(a)anthracene & 2.1 & $<1.7$ & NA & $<0.35$ & $<0.34$ \\
\hline & Benzene & 1.4 & $<0.6$ & NA & $<0.66$ & $<0.63$ \\
\hline & Benzo(a)pyrene & 0.21 & $<0.085$ & NA & $<0.018$ & $<0.017$ \\
\hline & Benzo(b)fluoranthene & 21 & $<1.7$ & NA & $<0.35$ & $<0.34$ \\
\hline & Benzo(g,h,i)perylene & 29,000 & $<1.7$ & NA & $<0.35$ & $<0.34$ \\
\hline & Benzo(k)fluoranthene & 21 & $<1.7$ & NA & $<0.35$ & $<0.34$ \\
\hline & Chrysene & 210 & $<1.7$ & NA & $<0.35$ & $<0.34$ \\
\hline & Ethylbenzene & 400 & $<0.6$ & NA & $<0.66$ & $<0.63$ \\
\hline & Fluoranthene & 22,000 & $<1.7$ & NA & $<0.35$ & $<0.34$ \\
\hline & Fluorene & 26,000 & $<1.7$ & NA & $<0.35$ & $<0.34$ \\
\hline & Naphthalene & 190 & $<0.6$ & NA & $<0.66$ & $<0.63$ \\
\hline & n-Butylbenzene & 240 & $<0.6$ & NA & $<0.66$ & $<0.63$ \\
\hline & n-Propylbenzene & 240 & $<0.6$ & NA & $<0.66$ & $<0.63$ \\
\hline & Phenanthrene & 100,000 & $<1.7$ & NA & $<0.35$ & $<0.34$ \\
\hline & Pyrene & 29,000 & $<1.7$ & NA & $<0.35$ & $<0.34$ \\
\hline & Toluene & 520 & $<0.6$ & NA & $<0.66$ & $<0.63$ \\
\hline & Xylenes & 420 & $<0.6$ & NA & $<0.66$ & $<0.63$ \\
\hline
\end{tabular}

mg/kg: milligram(s) per kilogram

NA: not analyzed for in sample

TPH: total petroleum hydrocarbons 


\subsubsection{Corrective Action Site 29-01-01, Hydrocarbon Stain}

This site consists of soil potentially impacted by a release from an active diesel tank. Soil samples were collected from beneath the tank spigot and analyzed for TPH using EPA Method 8015B and for the hazardous constituents of TPH using EPA Methods 8260 and 8270. Analytical results are summarized in Table 3. Samples contained TPH at concentrations greater than the action level of $100 \mathrm{mg} / \mathrm{kg}$; however, the hazardous constituents of TPH did not exceed the action levels. Therefore, TPH was not considered a COC, and no further action was required.

Table 3. Analytical Results for Corrective ACtion Site 29-01-01

\begin{tabular}{|c|c|c|c|c|}
\hline \multirow{2}{*}{\multicolumn{2}{|c|}{ ANALYTE }} & \multirow{2}{*}{$\begin{array}{c}\text { ACTION LEVEL } \\
\text { (mg/kg) }\end{array}$} & \multicolumn{2}{|c|}{ SAMPLE RESULTS (mg/kg) } \\
\hline & & & $1-1$ & $1-2$ \\
\hline \multirow{3}{*}{$\begin{array}{c}\text { Petroleum } \\
\text { Hydrocarbons }\end{array}$} & Diesel & - & 13,000 & 13,000 \\
\hline & Motor Oil & - & $<2,220$ & $<2,220$ \\
\hline & TPH & 100 & 13,000 & 13,000 \\
\hline \multirow{20}{*}{$\begin{array}{c}\text { Hazardous } \\
\text { Constituents of } \\
\text { TPH }\end{array}$} & 1,3,5-Trimethylbenzene & 70 & $<0.69$ & $<0.65$ \\
\hline & 2-Methylnaphthalene & 190 & $<3.7$ & $<3.7$ \\
\hline & Anthracene & 100,000 & $<3.7$ & $<3.7$ \\
\hline & Benzo(a)anthracene & 2.1 & $<0.05$ & $<.05$ \\
\hline & Benzene & 1.4 & $<0.69$ & $<0.65$ \\
\hline & Benzo(a)pyrene & 0.21 & $<0.2$ & $<0.2$ \\
\hline & Benzo(b)fluoranthene & 21 & $<3.7$ & $<3.7$ \\
\hline & Benzo(g,h,i)perylene & 29,000 & $<3.7$ & $<3.7$ \\
\hline & Benzo(k)fluoranthene & 21 & $<3.7$ & $<3.7$ \\
\hline & Chrysene & 210 & $0.50(\mathrm{~J})$ & $0.33(\mathrm{~J})$ \\
\hline & Ethylbenzene & 400 & $<0.69$ & $<0.65$ \\
\hline & Fluoranthene & 22,000 & $0.19(\mathrm{~J})$ & $0.39(\mathrm{~J})$ \\
\hline & Fluorene & 26,000 & $<3.7$ & $<3.7$ \\
\hline & Naphthalene & 190 & $<0.69$ & $<0.65$ \\
\hline & n-Butylbenzene & 240 & $<0.69$ & $<0.65$ \\
\hline & n-Propylbenzene & 240 & $<0.69$ & $<0.65$ \\
\hline & Phenanthrene & 100,000 & $<3.7$ & $<3.7$ \\
\hline & Pyrene & 29,000 & $0.79(\mathrm{~J})$ & $1.0(\mathrm{~J})$ \\
\hline & Toluene & 520 & $<0.69$ & $<0.65$ \\
\hline & Xylenes & 420 & $<0.69$ & $<0.65$ \\
\hline
\end{tabular}

$\mathrm{J}$ : estimated value mg/kg: milligram(s) per kilogram NA: not analyzed for in sample TPH: total petroleum hydrocarbons 


\subsection{DEVIATIONS FROM THE SAFER Plan AS APPROVED}

Deviations from the SAFER Plan (NNSA/NSO, 2008a) or its Addendum (NNSA/NSO, 2008b) were not necessary.

\subsection{Corrective ACtion SCHEdule As COMPleted}

Closure activities began in October 2008 and were completed in December 2008. Details of the schedule are provided in Table 4.

Table 4. Corrective Action Unit 134 Closure Activities Schedule

\begin{tabular}{|l|l|c|c||}
\hline \multicolumn{1}{|c|}{ CoRRECTIVE ACTION SITE } & \multicolumn{1}{|c|}{ ACTIVITY } & START DATE & END DATE \\
\hline $\begin{array}{l}\text { 03-01-03, Aboveground Storage } \\
\text { Tank }\end{array}$ & $\begin{array}{l}\text { Corrective action investigation of } \\
\text { tank }\end{array}$ & October 16, 2008 & October 16, 2008 \\
\hline $\begin{array}{l}\text { 15-01-05, Aboveground Storage } \\
\text { Tank }\end{array}$ & $\begin{array}{l}\text { Corrective action investigation } \\
\text { sampling }\end{array}$ & October 20, 2008 & October 20, 2008 \\
\hline 29-01-01, Hydrocarbon Stain & $\begin{array}{l}\text { Corrective action investigation } \\
\text { sampling }\end{array}$ & October 21, 2008 & October 21, 2008 \\
\hline $\begin{array}{l}\text { 03-01-03, Aboveground Storage } \\
\text { Tank }\end{array}$ & Removal and disposal of tank & October 27, 2008 & December 10, 2008 \\
\hline
\end{tabular}

\subsection{Site Plan/Survey Plat}

As-built drawings were not required for CAU 134 closure activities. 
CAU 134 Closure Report

Section: Closure Activities

Revision: 0

Date: June 2009

THIS PAGE INTENTIONALLY LEFT BLANK 


\subsection{WASTE DISPOSITION}

This section describes the waste streams generated during closure activities and their final disposition.

\subsection{WASTE Minimization}

Industry standard waste minimization practices were applied throughout the course of closure activities. These practices included performing radiological surveys of the tank to verify acceptance as sanitary waste at the Area 9 U10c Sanitary Landfill.

\subsection{WASTE DiSPOSAL}

Waste consisted of the tank removed from CAS 03-01-03, which was disposed as sanitary waste at the Area 9 U10c Sanitary Landfill after it had been screened for free-release according to the NV/YMP Radiological Control Manual (NNSA/NSO, 2004). Waste disposition documentation is included as Appendix C. 
CAU 134 Closure Report

Section: Waste Disposition

Revision: 0

Date: June 2009

THIS PAGE INTENTIONALLY LEFT BLANK 


\subsection{CLOSURE VERIFICATION RESULTS}

Site closure was verified by visual observations and site closure photographs to document that closure activities had been completed. Photographs documenting site conditions before and after closure activities are included as Appendix D.

\subsection{Data Quality Assessment}

Accurate and defensible analytical data were collected during the corrective action investigation phase of the project. Analytical data results are included as Appendix B. The following sections describe the quality assurance (QA) and quality control (QC) procedures, data validation process, and a reconciliation of the CSM with actual findings during closure activities. More detail on the QA/QC procedures can be found in the SAFER Plan for CAU 134 (NNSA/NSO, 2008a) and the QAPP (NNSA/NV, 2002).

\subsubsection{Quality Assurance and Quality Control Procedures}

Corrective action investigation samples were collected with disposable sampling equipment and placed in appropriately labeled sample containers secured with custody seals. All samples were labeled with a unique sample number, placed on ice, and transported under chain of custody. Standard QA/QC samples were collected (i.e., one blind duplicate per twenty samples). Samples were analyzed by certified offsite contract laboratories. Analytical results were validated at the laboratory using stringent QA/QC procedures, including matrix spike/matrix spike duplicates, spiked surrogate recovery analysis, verification of analytical results, and data quality indicator requirements. Detailed information regarding the QA/QC program requirements can be found in the QAPP (NNSA/NV, 2002).

\subsubsection{Data Validation}

Data validation was performed according to the QAPP (NNSA/NV, 2002), which is based on the EPA functional guidelines for data quality (EPA, 1994; 1999). Data were reviewed to ensure that samples were appropriately processed and analyzed and that the results are valid.

No anomalies were discovered in the data that would discredit any of the sample results. Data met the required data quality indicators (i.e., precision, accuracy, sensitivity, completeness, comparability, and representativeness). While only summary laboratory QC data are included in Appendix B, the complete datasets, including validation reports, are maintained in the project files and available upon request.

\subsubsection{Conceptual Site Models}

CSMs were developed and presented in the approved SAFER Plan for CAU 134 (NNSA/NSO, 2008a). The CSMs were confirmed by soil sample results and verified during closure activities.

\subsection{USE RESTRICTION}

Use restrictions were not implemented for CAU 134. 
CAU 134 Closure Report

Section: Closure Verification

Revision: 0

Date: June 2009

THIS PAGE INTENTIONALLY LEFT BLANK 


\subsection{CONCLUSIONS AND RECOMMENDATIONS}

\subsection{CONCLUSIONS}

The following site closure activities were performed at CAU 134 as documented in this CR:

- At CAS 03-01-03, Aboveground Storage Tank, no further action was required. However, as a BMP, the tank was removed for disposal as sanitary waste.

- At CAS 03-01-04, Tank, no further action was required, and no work was performed.

- At CAS 15-01-05, Aboveground Storage Tank, samples were collected to confirm that COCs are not present above action levels. No further action was required.

- At CAS 29-01-01, Hydrocarbon Stain, samples were collected to confirm that COCs are not present above action levels. No further action was required.

\subsection{Post-Closure ReQuirements}

No use restrictions were implemented, and there are no post-closure requirements.

\subsection{RECOMMENDATIONS}

Since closure activities for CAU 134 have been completed following the NDEP-approved SAFER Plan (NNSA/NSO, 2008a) and its Addendum (NNSA/NSO, 2008b) as documented in this report, NNSA/NSO requests the following:

- A Notice of Completion be provided by NDEP to NNSA/NSO for closure of CAU 134.

- The transfer of CAU 134 from Appendix III to Appendix IV, Closed Corrective Action Units, of the FFACO (1996; as amended February 2008). 
CAU 134 Closure Report

Section: Conclusions

Revision: 0

Date: June 2009

THIS PAGE INTENTIONALLY LEFT BLANK 


\subsection{REFERENCES}

EPA, see U.S. Environmental Protection Agency.

Federal Facility Agreement and Consent Order, 1996 (as amended February 2008). Agreed to by the State of Nevada; U.S. Department of Energy, Environmental Management; U.S. Department of Defense; and U.S. Department of Energy, Legacy Management.

Federal Facility Agreement and Consent Order, 2003. Use Restriction Posting Guidance.

FFACO, see Federal Facility Agreement and Consent Order.

NNSA/NSO, see U.S. Department of Energy, National Nuclear Security Administration Nevada Site Office.

NNSA/NV, see U.S. Department of Energy, National Nuclear Security Administration Nevada Operations Office.

U.S. Department of Energy, National Nuclear Security Administration Nevada Operations Office, 2002. Nevada Environmental Restoration Project Industrial Sites Quality Assurance Project Plan, Nevada Test Site, Nevada. DOE/NV--372-REV.3. Las Vegas, NV.

U.S. Department of Energy, National Nuclear Security Administration Nevada Site Office, 2004. NV/YMP Radiological Control Manual. DOE/NV/11718--079-REV 5. Las Vegas, NV.

U.S. Department of Energy, National Nuclear Security Administration Nevada Site Office, 2008a. Streamlined Approach for Environmental Restoration Plan for Corrective Action Unit 134: Aboveground Storage Tanks, Nevada Test Site, Nevada. DOE/NV--1275. Las Vegas, NV.

U.S. Department of Energy, National Nuclear Security Administration Nevada Site Office, 2008b. Addendum to the Streamlined Approach for Environmental Restoration Plan for Corrective Action Unit 134: Aboveground Storage Tanks, Nevada Test Site, Nevada. DOE/NV--1275-ADD. Las Vegas, NV.

U.S. Environmental Protection Agency, 1994. Guidance for the Data Quality Objectives Process. EPA QA/G-4. Washington, D.C.

U.S. Environmental Protection Agency, 1999. Contract Laboratory Program National Functional Guidelines for Organic Data Review. EPA540/R-99/008. Washington, D.C. 
CAU 134 Closure Report

Section: References

Revision: 0

Date: June 2009

\section{THIS PAGE INTENTIONALLY LEFT BLANK}




\section{APPENDIX A*}

\section{DATA QUALITY OBJECTIVES}

* As presented and published in Section 3.0 of the approved Streamlined Approach for Environmental Restoration Plan for Corrective Action Unit 134: Aboveground Storage Tanks, Nevada Test Site, Nevada, 2008, DOE/NV--1275. Las Vegas, NV. 
CAU 134 Closure Report

Section: Appendix A

Revision: 0

Date: June 2009

THIS PAGE INTENTIONALLY LEFT BLANK 


\subsection{DATA QUALITY OBJECTIVES}

The DQO process is a seven-step systematic planning method based on the scientific method that was used to plan data collection and field investigation activities for CAU 134, Aboveground Storage Tanks. The seven steps of the DQO process presented in this report were developed according to the EPA Guidance on Systematic Planning Using the Data Quality Objectives Process (EPA, 2006). DQOs are designed to ensure that the data collected will provide sufficient and reliable information to support the potential closure alternatives for CAU 134. A closure strategy for CAU 134 has been identified; however, additional data are needed to confirm the existence and extent of contamination, if any, and to affirm the closure decision.

During DQO discussions for CAU 134, data needed to resolve problem statements and decision statements were identified. Criteria for data collection and analysis were defined and agreed upon, and the appropriate quality assurance (QA)/quality control (QC) required for particular data collection activities were assigned. The analytical methods and reporting limits prescribed through the DQO process and the data quality indicators (DQIs) for laboratory analysis, such as precision and accuracy requirements, are provided in more detail in Section 7.0 of this SAFER Plan.

\subsection{SUMMARY OF DQO ANALYSIS}

\subsubsection{State the Problem (Step 1)}

Step 1 of the DQO process describes the problem to be studied and develops a conceptual site model (CSM) to gain a sufficient understanding in defining the problem.

The problem statement for CAU 134 is, “Additional information is required to verify existing information; confirm the absence or presence of COCs; identify the extent of contamination, if present; and affirm the closure decision.” A COC is defined as any contaminant in the soil that is present at concentrations exceeding its FAL.

\subsubsection{1 $\underline{\text { CSM }}$}

The CSM is used to organize and communicate information about site characteristics. It reflects the best interpretation of available information at any point in time. The CSM is based on historical documentation, personnel interviews, site process knowledge, site walkdowns, photographs, engineering drawings, field screening, and analytical results. The CSM describes the most probable scenario for current conditions at the site and defines the assumptions that are the basis for identifying an appropriate sampling strategy and data collection methods.

The CSM for CAU 134 consists of localized, limited contamination sources (i.e., ASTs) that have released none, all, or a portion of their contents to the surrounding soil. The CSM for each of the CASs is presented in the following paragraphs.

CAS 03-01-03, Aboveground Storage Tank, consists of one 25-ft-long, 12-ft-diameter AST and soil below the AST that may have been impacted by the AST contents. As identified on engineering drawings and by LANL employees, the tank was associated with the UMBER (U3em) test, which was conducted by LANL in 1967 (Henderson, 2007; Holmes and Narver, 1967a; 1967b; 1967c). The tank was originally a pressure vessel used elsewhere (unknown 
location). Any hazards associated with gases contained within the tank would have been mitigated when the tank was retrofitted in 1967, at which time the lining in the tank was removed. The tank was retrofitted and filled with clean (new) drilling mud, with the intent of remotely plugging the U3em (ground zero) borehole after the test. A fire hose was connected to the tank, through which the mud would have been pumped into the borehole. It did not work and was never attempted again.

According to LANL personnel (Henderson, 2007), the contents of the tank would not have been impacted by the test, and the outside of the tank would have been impacted the same as the surrounding area. The surrounding area is not posted for radioactivity. A site visit on December 19, 2007, confirmed that there are no radiological postings, that the tank valve is open and the tank is therefore not pressurized, and that radiological field-screening levels are no higher at the open valve or the tank surface than in the surrounding area. The CSM for this CAS therefore is that of a container that has adequately contained its contents, which is uncontaminated mud. No further investigation or sampling is needed to confirm this CSM. Existing field-screening results are available in the Management and Operations Contractor (M\&OC) files in Mercury, Nevada. This CSM is presented in Figure 3.

CAS 03-01-04, Tank, consists of one 16-ft-diameter, 141/2-ft-tall potable water tank. As identified on engineering drawings, the tank was used to supply water to the Core Handling Building at the Core Complex in Area 3 (Holmes and Narver, 1967d; 1967e; 1967f). This facility was never connected to the NTS public water system because of the distance to the nearest water supply well; therefore, water was trucked to and stored within this tank. As is indicated on the drawings, the tank stored water that was used for showers, sinks, and other water supply sources within the Core Handling Building. "POTABLE WATER" is stenciled onto the side of the tank (see Figure 2). Process knowledge is adequate to state that there are no COCs associated with this site and no further action is required.

CAS 15-01-05, Aboveground Storage Tank, consists of one old, metal, rusty, dented, empty 1,000-gal AST (approximately $12 \mathrm{ft}$ long by $4 \mathrm{ft}$ diameter) and soil below the AST that may have been impacted by the AST contents. The tank is located in the vicinity of other debris near the Climax Mine, which pre-dates the existence of the NTS. The tank is located on a steep, rocky hillside below the mine entrance. It appears that the tank either fell and rolled from its original location near the mine entrance, or was dumped at the side of the road and rolled to its present location. The tank is currently open and there are no biasing factors to indicate that a release has occurred at this location. Radiological surveys conducted during site visits show that radioactivity is less than the free-release limits.

Historical use of the tank is undocumented, although it appears to pre-date the NTS. For mining operations during this era, similar tanks were typically used to store either water or fuel. If the tank did release its contents to the soil, a slow release would have impacted soil directly below the tank and down to bedrock, after which it would flow downhill over the top of bedrock at the alluvium-bedrock interface. This would not have impacted surface soil except in the immediate vicinity of the tank, with a catastrophic release impacting a larger surface area. 

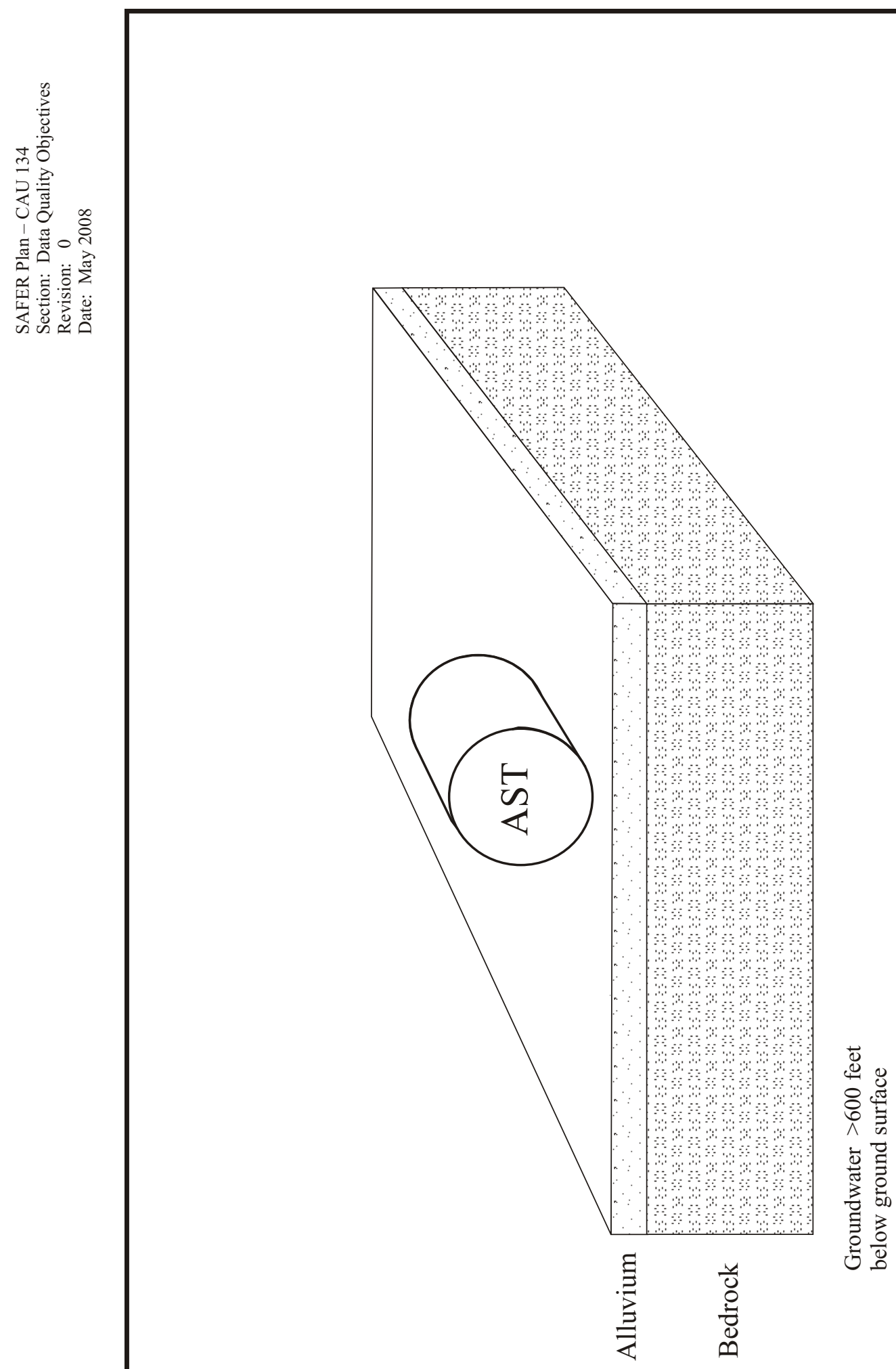

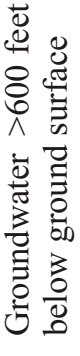

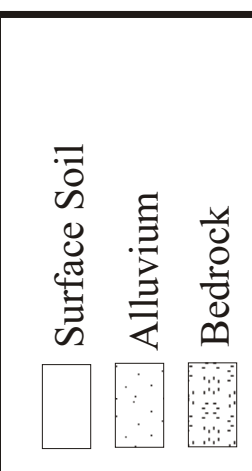

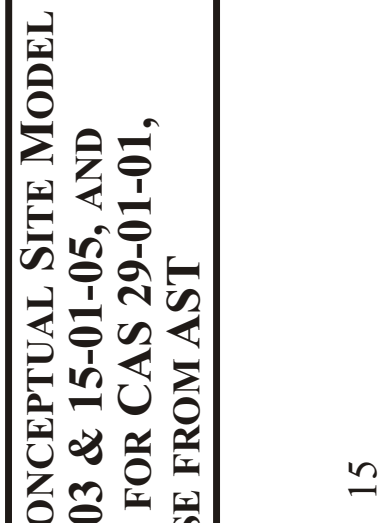

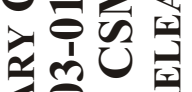
$\sum$ 四

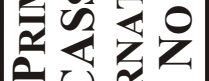
는

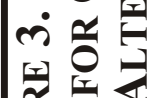
 
The primary driver for contaminant migration would be rain driving the contaminant plume farther down the side of the hill. With annual average rainfall of 6-7 inches (Air Resources Laboratory, Special Operations and Research Division, 2004), migration would be minimal. There is little likelihood that a 1,000-gal release (i.e., the capacity of the tank) would have impacted groundwater, which is at least $600 \mathrm{ft}$ below ground surface (DOE/NV, 2000a), or any drinking water wells, the nearest or which is more than 6 mi away.

The tank likely arrived at its current location empty; therefore, the Primary CSM is that soil below the AST has not been contaminated by the tank contents. The Alternate CSM assumes that the contents of the AST (some or all) consisted of petroleum hydrocarbons, not water, and were released to the soil at its current location. The Primary CSM is presented in Figure 3. The Alternate CSM is presented in Figure 4.

CAS 29-01-01, Hydrocarbon Stain, consists of diesel-contaminated rocky soil at the base of an active 2,000-gal diesel AST. The tank stores fuel for the generator at the Shoshone Receiver Site, which is used for communications at the NTS. This facility, including the associated tank, is expected to remain active as long as radio transmission/receiving capabilities are needed at the NTS. Because the tank is active, it is not a part of this CAS. Overhead power lines and guy lines for the receiver tower are present to the west of the site, and aboveground fuel lines are present between the tank and the adjacent building.

There is no evidence of recent releases from the tank. A 1991 report identifying potential ER sites on the NTS (REECo, 1991) identified that the tank was leaking and that stained soil was present below the release point. An August 27, 1991, memorandum (Haworth, 1991) reports that a site visit was conducted, and staining, although present, was only minor. Recent site visits show that minor staining is still visible. The Primary CSM for this site is that a release from the tank occurred. The Alternate CSM assumes that a release has not occurred. Figure 4 depicts the Primary CSM, and Figure 3 depicts the Alternate CSM for CAS 29-01-01.

Waste that is expected to be generated from CAU 134 consists of the ASTs from CASs 03-01-03 and 15-01-05, disposable sampling equipment, and personal protective equipment. If additional CSM elements that are outside the scope of the CSM are identified during closure activities, the situation will be reviewed and a recommendation will be made regarding to how to proceed. In such cases, the NDEP and the NNSA/NSO will be notified and given the opportunity to comment on, or concur with, the recommendation. 


\section{CAS 15-01-05}

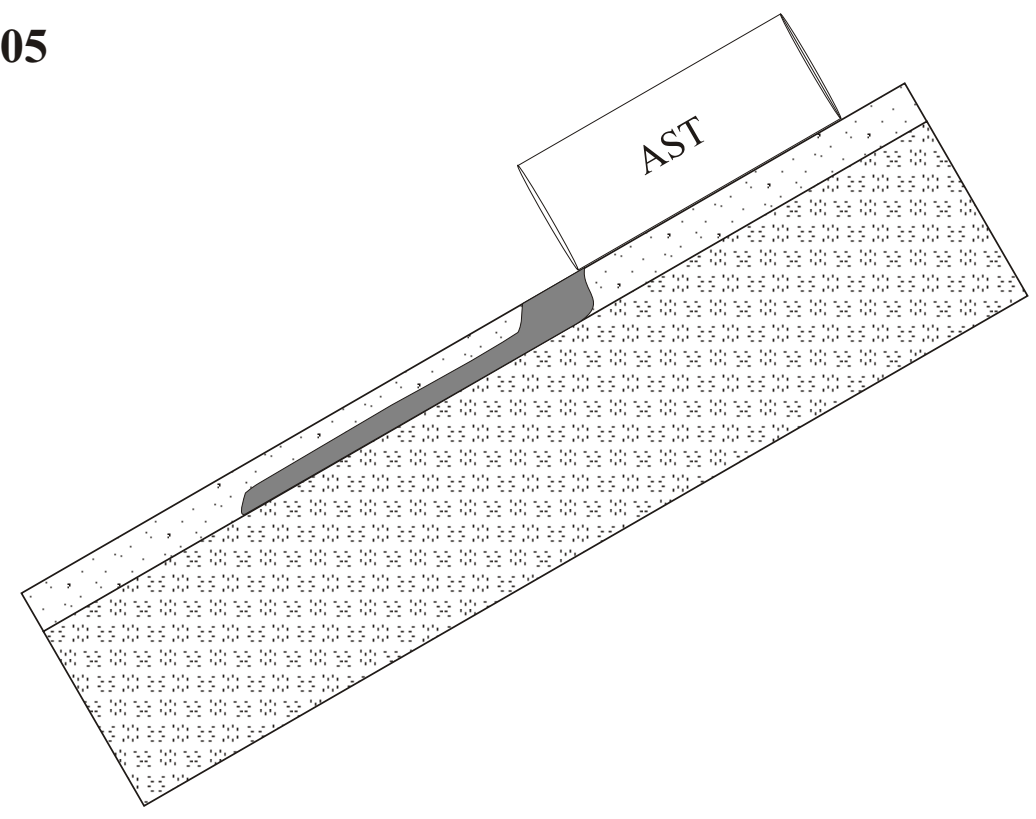

CAS 29-01-01

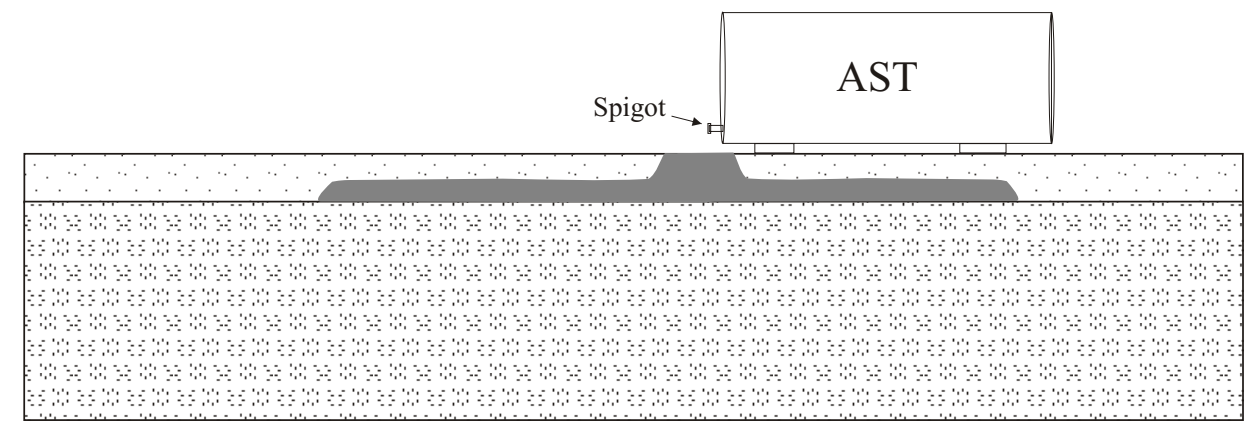

\section{LEGEND}

Contamination

Alluvium

Bedrock

Drawings not to scale

Figure 4. Primary Conceptual Site Model for CAS 29-01-01, AND ALTERNATE CSM FOR CAS 15-01-05, RELEASE FROM AST 


\subsubsection{Identify The GoAl OF The Study (SteP 2)}

Step 2 of the DQO process identifies the questions that the study will attempt to resolve and what actions may result. The goal of the study is to answer the following questions satisfactorily. The questions are arranged in the order that they will be addressed.

1. Is soil beneath the ASTs in CASs 15-01-05 and 29-01-01 impacted with contamination that exceeds action levels? The result will be a decision for "no further action" required at the site or that additional evaluation is required to determine if FALs have been exceeded.

2. If the soil is impacted above action levels, what is the extent of the contamination that exceeds action levels? The result will be to evaluate whether the contamination can be excavated or to identify the boundary of the area that should be use-restricted.

3. Has excavation of soil reduced the contamination to concentrations less than the FALs? The result will be to verify that resulting concentrations are at acceptable levels or, if not, to continue excavating until that result has been reached or identify the area that should be use-restricted.

\subsubsection{IDENTIFY INFORMATION INPUTS (STEP 3)}

Step 3 of the DQO process identifies the information available, the information needed, the sources of information, and sampling and analysis methods that can meet the data requirements. Table 1 presents available information, information that is needed, and proposed methods to obtain the information that is needed to meet the closure goal.

\subsubsection{Information Needs}

To confirm the CSM and determine the nature and extent of contamination, data must be collected and analyzed using the following criteria:

- Data will be collected from locations most likely to contain contamination (judgmental sampling approach) at CASs 15-01-05 and 29-01-01.

- The analytical suite selected will be adequate to detect contaminants present in the samples.

- Where data show that contamination is present at concentrations greater than the FALs, data will be collected to identify the extent of contamination.

- If contaminated soil is excavated, cleanup verification samples will be collected to verify that remaining concentrations are less than the FALs.

\subsubsection{Sources of Information}

Information needed to satisfy the decisions will be generated by collecting soil samples. 
Table 1. Information NeEdS for Decision Resolution

\begin{tabular}{|c|c|c|c|}
\hline $\begin{array}{l}\text { DECISIONS } \\
\text { NEEDED }\end{array}$ & $\begin{array}{l}\text { INFORMATION } \\
\text { AVAILABLE }\end{array}$ & $\begin{array}{l}\text { INFORMATION } \\
\text { NEEDED }\end{array}$ & $\begin{array}{l}\text { PROPOSED METHOD(s) TO OBTAIN } \\
\text { INFORMATION NEEDED }\end{array}$ \\
\hline \multirow[t]{3}{*}{$\begin{array}{l}\text { Disposal pathway } \\
\text { for the ASTs (no } \\
\text { decisions needed) }\end{array}$} & $\begin{array}{l}\text { CAS 03-01-03: } \\
\text { (1) Process knowledge that the } \\
\text { tank contents are } \\
\text { uncontaminated. } \\
\text { (2) Field-screening results } \\
\text { showing the tank can be free- } \\
\text { released for radioactivity. }\end{array}$ & CAS 03-01-03: None & CAS 03-01-03: Not applicable \\
\hline & $\begin{array}{l}\text { CAS 03-01-04: } \\
\text { (1) Process knowledge that the } \\
\text { tank contained potable water, } \\
\text { which has no COCs. }\end{array}$ & CAS 03-01-04: None & CAS 03-01-04: Not applicable \\
\hline & $\begin{array}{l}\text { CAS 15-01-05: } \\
\text { (1) Resource Conservation and } \\
\text { Recovery Act-empty based on } \\
\text { visual observations through } \\
\text { access port. } \\
\text { (2) Field-screening results } \\
\text { showing the tank can be free- } \\
\text { released for radioactivity. }\end{array}$ & CAS 15-01-05: None & CAS 15-01-05: Not applicable \\
\hline
\end{tabular}


Date: May 2008

Table 1. Information NeEds for Decision Resolution (Continued)

\begin{tabular}{|c|c|c|c|}
\hline $\begin{array}{l}\text { DECISIONS } \\
\text { NEEDED }\end{array}$ & $\begin{array}{l}\text { INFORMATION } \\
\text { AVAILABLE }\end{array}$ & $\begin{array}{l}\text { INFORMATION } \\
\text { NEEDED }\end{array}$ & $\begin{array}{l}\text { PROPOSED METHOD(s) TO OBTAIN } \\
\text { INFORMATION NEEDED }\end{array}$ \\
\hline $\begin{array}{l}\text { 1. Is soil impacted } \\
\text { with } \\
\text { contamination that } \\
\text { exceeds action } \\
\text { levels? }\end{array}$ & $\begin{array}{l}\text { CAS 03-01-03: Process } \\
\text { knowledge and field-screening } \\
\text { results for radioactivity. } \\
\text { CAS 03-01-04: Process } \\
\text { knowledge of tank contents and } \\
\text { use. } \\
\text { CAS 15-01-05: Field-screening } \\
\text { results for radioactivity. } \\
\text { CAS 29-01-01: Process } \\
\text { knowledge that a release from the } \\
\text { tank has occurred. No analytical } \\
\text { results are available. }\end{array}$ & $\begin{array}{l}\text { CAS 03-01-03: None } \\
\text { CAS 03-01-04: None } \\
\text { CAS 15-01-05: Concentrations } \\
\text { of total petroleum } \\
\text { hydrocarbons, volatile organic } \\
\text { compounds (VOCs), and } \\
\text { semi-volatile organic } \\
\text { compounds (SVOCs), if any, in } \\
\text { soil beneath the AST and in the } \\
\text { AST's original location, if } \\
\text { located. } \\
\text { CAS 29-01-01: } \\
\text { Concentrations of diesel, } \\
\text { VOCs, and SVOCs in soil at } \\
\text { location previously reported as } \\
\text { being stained. }\end{array}$ & $\begin{array}{l}\text { CAS 03-01-03: Not applicable } \\
\text { CAS 03-01-04: Not applicable } \\
\text { CAS 15-01-05: Collect soil samples from beneath the AST in } \\
\text { location(s) where the AST most likely released its contents (i.e., } \\
\text { beneath openings in the tank). }\end{array}$ \\
\hline
\end{tabular}


Table 1. Information NeEds for Decision Resolution (Continued)

\begin{tabular}{|c|c|c|c|}
\hline $\begin{array}{l}\text { DECISIONS } \\
\text { NEEDED }\end{array}$ & $\begin{array}{l}\text { INFORMATION } \\
\text { AVAILABLE }\end{array}$ & $\begin{array}{l}\text { INFORMATION } \\
\text { NEEDED }\end{array}$ & $\begin{array}{l}\text { PROPOSED METHOD(s) TO OBTAIN } \\
\text { INFORMATION NEEDED }\end{array}$ \\
\hline $\begin{array}{l}\text { 2. What is the extent } \\
\text { of contamination } \\
\text { exceeding the } \\
\text { action level (only } \\
\text { if FALs are } \\
\text { exceeded at CASs } \\
\text { 15-01-05 or } \\
29-01-01 \text { )? }\end{array}$ & None & $\begin{array}{l}\text { Analytical results that bound } \\
\text { the area of contamination } \\
\text { exceeding action levels. }\end{array}$ & $\begin{array}{l}\text { a. Collect a minimum of three surface soil samples surrounding } \\
\text { the original sample to bound the surface contamination. } \\
\text { Collect additional step-out samples until the extent of surface } \\
\text { contamination exceeding the FALs has been identified. } \\
\text { b. Collect a minimum of one soil sample from a location } \\
\text { downslope of the identified surface contamination. The } \\
\text { sample should be collected from just above the bedrock } \\
\text { interface. This sample will be used to bound the extent of } \\
\text { contamination that exceeds the FALs. If concentrations at the } \\
\text { step-out locations exceed the FALs, then additional step-out } \\
\text { samples will be collected. } \\
\text { Note: Field screening for petroleum hydrocarbons may be used } \\
\text { to guide sample collection activities. }\end{array}$ \\
\hline $\begin{array}{l}\text { 3. If soil is } \\
\text { excavated, has } \\
\text { excavation of } \\
\text { soil reduced the } \\
\text { contamination to } \\
\text { concentrations } \\
\text { less than the } \\
\text { FALs? }\end{array}$ & $\begin{array}{l}\text { Field screening for total } \\
\text { petroleum hydrocarbons (TPH), } \\
\text { collected as soil is excavated. }\end{array}$ & $\begin{array}{l}\text { Analytical results confirming } \\
\text { that contamination levels have } \\
\text { been reduced to acceptable } \\
\text { levels. }\end{array}$ & $\begin{array}{l}\text { Collect samples from base and sides of excavation to verify } \\
\text { remaining levels at less than action levels. Analyze only for } \\
\text { what was detected at concentrations above action level in } \\
\text { sample(s) from excavated soil. Collect a minimum of } \\
\text { (a) } 1 \text { sample from base of excavation and (b) } 2 \text { samples from } \\
\text { sidewall if excavation is smaller than 1-ft diameter, or } 3 \text { samples } \\
\text { if excavation is larger than 1-ft diameter. }\end{array}$ \\
\hline
\end{tabular}




\section{Qualitative Data}

Qualitative data identify or describe the characteristics or components of the site. The QA/QC requirements are the least rigorous on data collection methods and measurement systems for qualitative data. The intended use of the data is for information purposes, to refine conceptual models, and to guide investigations rather than resolve primary decisions. This measurement of quality is typically assigned to historical information and data where QA/QC may be highly variable or not known. Professional judgment is often used to generate qualitative data.

Visual observations will be made to identify the presence of biasing factors such as the location of openings within the ASTs.

\section{Semi-quantitative Data}

Semi-quantitative data indirectly measure the quantity or amount of a characteristic or component. Inferences are drawn about the quantity or amount of a characteristic or component because a correlation has been shown to exist between the indirect measurement and the results from a quantitative measurement. The QA/QC requirements on semi-quantitative collection and measurement systems are high but may not be as rigorous as for quantitative data. Semi-quantitative data contribute to decision making but are not used alone to resolve primary decisions. Field-screening data are generally considered semi-quantitative. The data are often used to guide investigations toward quantitative data collection.

If total petroleum hydrocarbons (TPH) are present at concentrations greater than the action level at CAS 15-01-05 or CAS 29-01-01, then TPH field-screening may be used to identify the extent of contamination greater than the action level. These field-screening techniques will provide semi-quantitative data that can be used to guide sample collection (e.g., obtain locations for biased sample collection) and waste management activities.

\section{Quantitative Data}

Quantitative data measure the quantity or amount of a characteristic or component. These data require the highest level of QA/QC in collection and measurement systems because the intended use of the data is to resolve primary decisions and/or to verify that closure standards have been met. Laboratory analytical data are generally considered quantitative.

A judgmental (biased) sampling approach will be used to collect samples from beneath the ASTs at CASs 15-01-05 and 29-01-01. Biasing factors consist of soil that is stained, located below AST openings, and/or located where staining has been noted.

Samples collected from CAS 15-01-05 will be analyzed for TPH. Samples from CAS 29-01-01 will be analyzed for diesel-range petroleum hydrocarbons. If results show that samples have been impacted at concentrations greater than the TPH action level, then additional samples will be collected to identify whether volatile organic compounds (VOCs) and semi-volatile organic compounds (SVOCs) contained in diesel fuel are greater than action levels (i.e., the FALs). If the FALs are exceeded, then additional samples will be collected to identify the extent of contamination.

Clean closure is not anticipated based on the shallow bedrock at both locations and the presence of the active tank at CAS 29-01-01; however, clean closure may be possible if extent of 
contamination is minimal. If contaminated soil is excavated, then additional samples will be collected and analyzed for those compounds that exceeded the FALs.

Samples will be submitted to analytical laboratories meeting the quality criteria stipulated in the Industrial Sites QAPP (NNSA/NV, 2002). A minimum of 10 percent of the data used to support DQO decisions will be validated. Sample collection and handling activities will follow standard procedures.

\subsubsection{Define the Boundaries OF The Study (STEP 4)}

Step 4 of the DQO process defines the target population of interest, specifies the spatial boundaries and time constraints of that population pertinent for decision making, and determines practical constraints on data collection.

\subsubsection{Population of Interest}

The population of interest to resolve the decisions consists of the ASTs at CASs 03-01-03 and 15-01-05 and of soil containing petroleum hydrocarbons greater than the action level for CASs 15-01-05 and 29-01-01.

\subsubsection{Spatial Boundaries}

CAS boundaries and proposed sample locations are described below. The spatial boundaries include the following:

- CAS 03-01-03 consists of the AST and its contents. The CAS boundary is considered to be the AST perimeter plus $5 \mathrm{ft}$ (Figure 5).

- CAS 15-01-05 consists of the AST and soil that has been impacted by a release from the tank at its current location and, if found, at its original location. The CAS boundary is considered to be the AST perimeter plus $10 \mathrm{ft}$ uphill and laterally, and $30 \mathrm{ft}$ downhill (Figure 6). If a subsurface sample is collected, it may be collected at a downhill location outside of the CAS boundary. This may be needed because of the extreme slope at this CAS and the inability to safely excavate at the tank's current location.

- CAS 29-01-01 consists of soil that has been impacted by a release from the associated diesel tank. The CAS boundary is considered to be the AST perimeter plus $5 \mathrm{ft}$ on its south end, $20 \mathrm{ft}$ laterally, and $30 \mathrm{ft}$ on its north end, where the release was reported to have occurred (Figure 7).

\subsubsection{Time Constraints}

The study data should be collected considering the length of time that will be required to complete the closure process and the Closure Report (CR), as allowed for by the SAFER process under the FFACO (FFACO, 1996; as amended February 2008). Data will be collected at times that meet the security and safety constraints of the NTS and at times when weather conditions allow adequate site access and safe working conditions. Time constraints that may affect the schedule of this project include the following:

- Approval of SAFER Plan and DQOs

- Activities that restrict access to CAS 15-01-05, which is beyond a barricaded gate requiring approval to proceed 


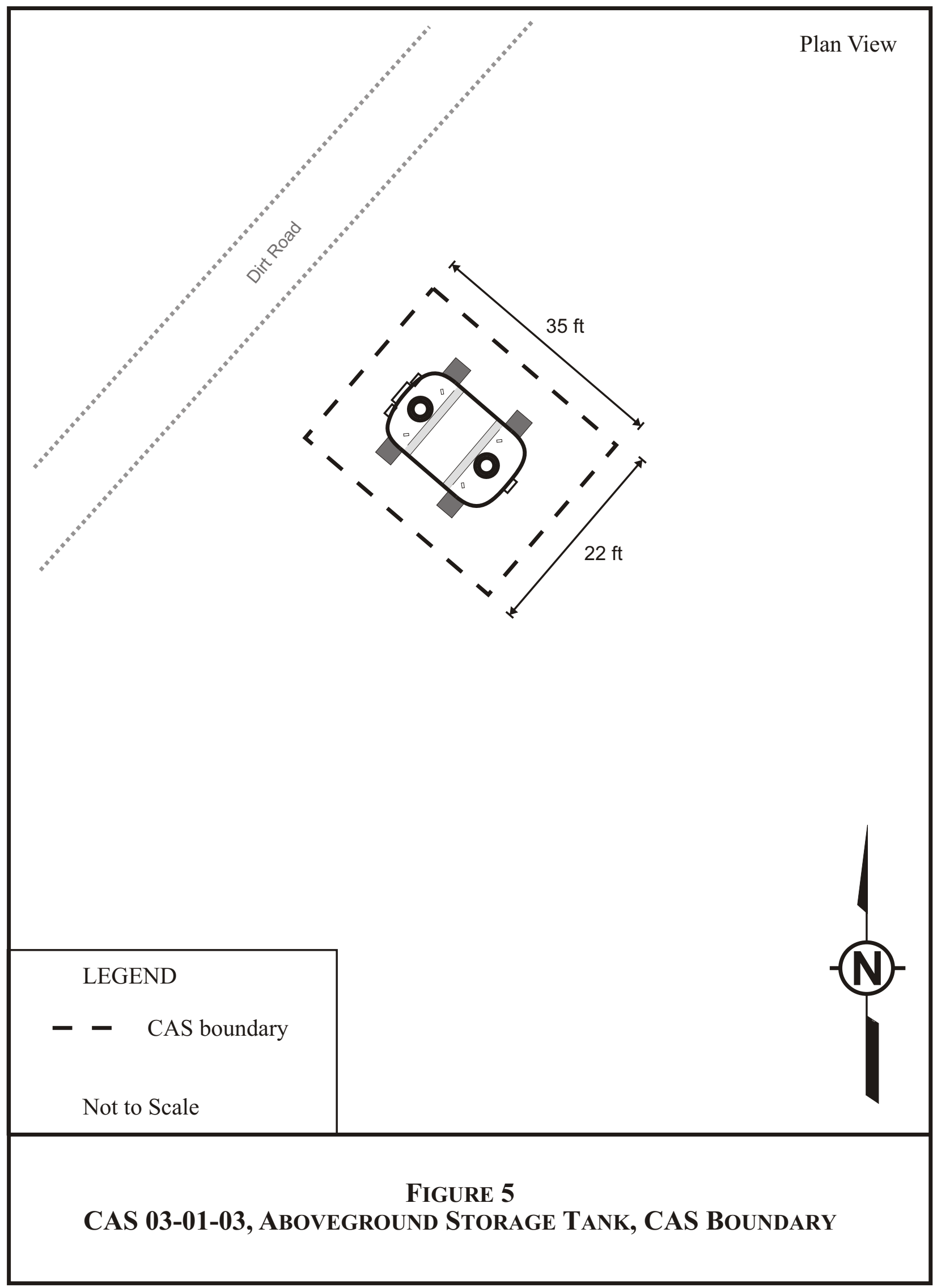




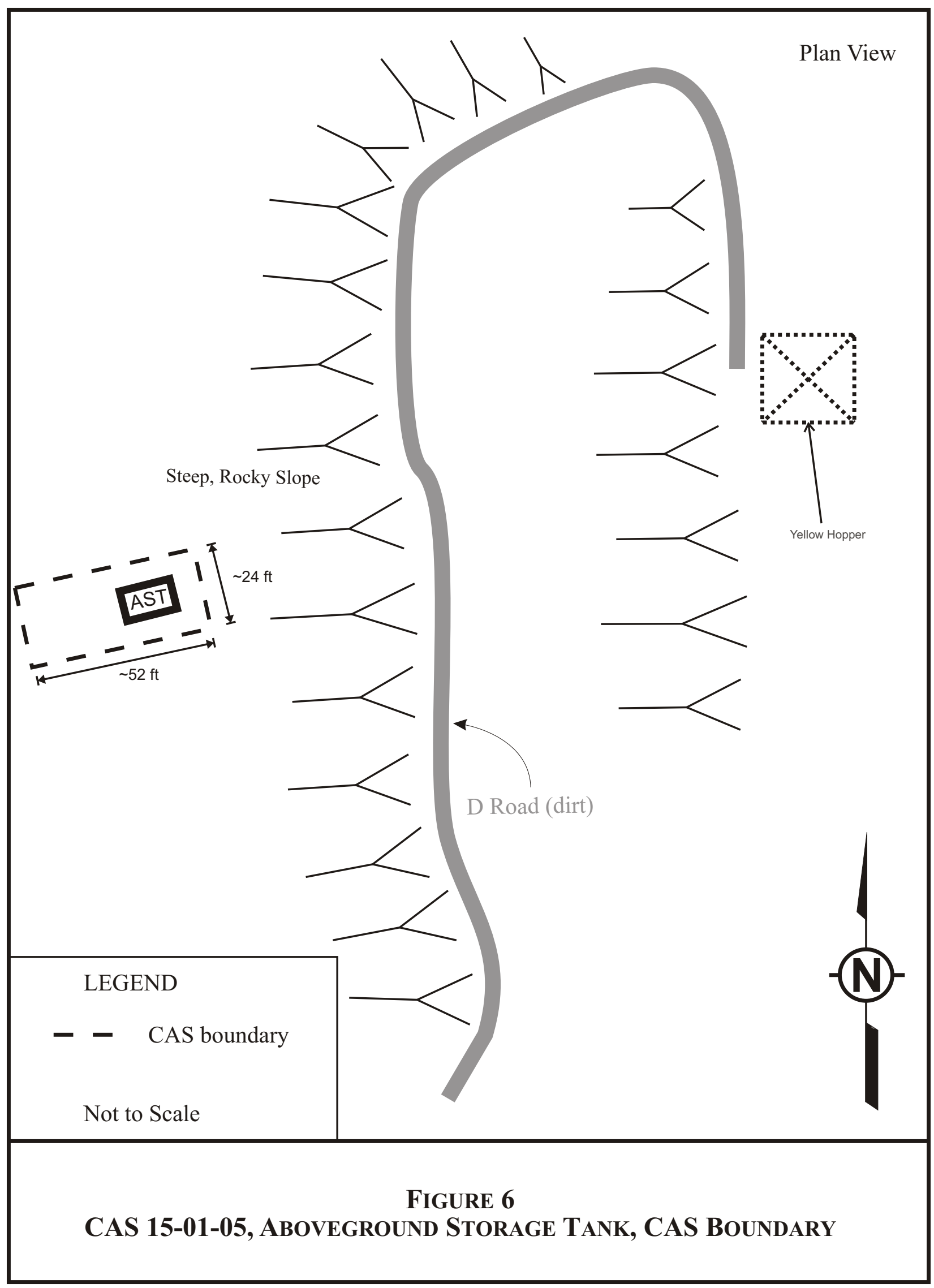




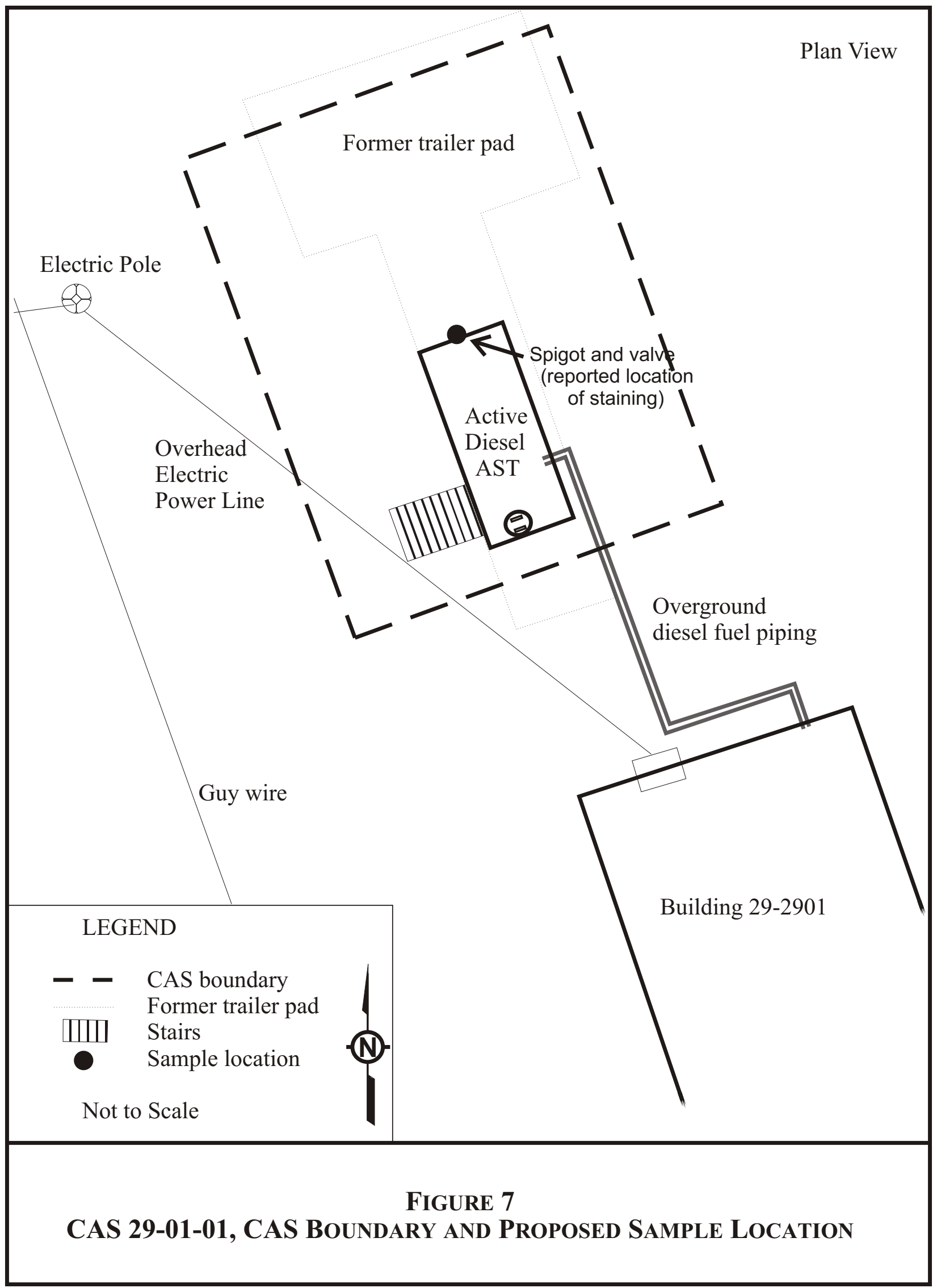


Closure activities are currently scheduled to begin in fiscal year (FY) 2009.

\subsubsection{Practical Constraints}

Other constraints that may affect the ability to collect data include the following:

- Equipment access and availability at NTS

- Road condition for CAS 15-01-05, which is a primitive, unmaintained road in poor condition

- Road condition for CAS 29-01-01, which is not well maintained

- Adverse weather conditions (e.g., snow and ice in the winter months, especially at the sites in Areas 15 and 29)

- Acceptance of waste disposal pathways

- Other unsafe working conditions

\subsubsection{Develop the Analytic Approach (Step 5)}

Step 5 of the DQO process develops a decision rule statement ("If..., then...") that defines the conditions under which possible alternative actions will be chosen. In this step, the statistical parameters that characterize the population of interest are specified, the action levels are specified, and the measurement and analysis limits capable of detecting action levels are confirmed.

\subsubsection{Population Parameters}

Each sample result within the population of interest defined in Step 4 will be compared to the action levels to determine the appropriate resolution to the decisions.

\subsubsection{Decision Rules}

The decision rules are as follows.

\section{Decision I}

- If concentrations in soil samples collected from CASs 15-01-05 or 29-01-01 are less than the preliminary action level (PAL), then no further action is required. Closure is complete at this CAS.

- If concentrations in soil samples collected from CASs 15-01-05 or 29-01-01 are greater than the PAL, then the appropriate FALs will be determined above which a closure action is required. Additional samples will be collected, as required. If concentrations in the soil exceed the FALs, then proceed to Decision II for this CAS.

\section{Decision II}

- If soil samples collected from CAS 15-01-05 or 29-01-01 show that concentrations exceed the FAL, then a minimum of three step-out surface soil samples will be collected to bound the area with concentrations greater than the FAL. Additional step-out samples will be collected until the lateral surface area of contamination has been bounded. In addition, a minimum of one sample will be collected from just above the bedrock interface, in the bedrock down slope direction, to bound contamination that has reached the bedrock interface 
and migrated down slope. Additional samples will be collected as needed to bound contamination that has migrated along the alluvium-bedrock interface.

\section{Decision III}

- If the extent of contamination is minimal and can be remediated by excavation, then contaminated soil will be excavated and verification samples will be collected. If verification sample results show that chemical concentrations are less than the FALs, then closure is complete. A minimum of one sample will be collected from the base of the excavation. A minimum of two samples will be collected from sidewalls of excavations $1 \mathrm{ft}$ or less in diameter, and a minimum of three samples will be collected from the sidewalls of excavations larger than $1 \mathrm{ft}$ in diameter to confirm that closure is complete. Samples will only be analyzed for those contaminants that exceeded the action level and triggered the requirement to excavate soil. Ability to excavate may not be possible because of the shallow depth to bedrock and/or unsafe conditions caused by sloping terrain.

- A UR will be implemented for remaining area(s) of contamination that exceed the action level(s).

\subsubsection{Action Levels}

The following action levels have been established for CAU 134:

- TPH: The PAL will be 100 milligrams per kilogram (mg/kg), as is established in the Nevada Administrative Code (NAC), Section 445A.2272, "Contamination of soil: Establishment of action levels" (NAC, 2006).

- VOCs and SVOCs: FALs will be based on the concentration of individual chemical components of diesel and are defined as the EPA Region 9 risk-based preliminary remediation goals (PRGs) for chemical constituents in industrial soils (EPA, 2004). Table 2 provides the list of volatile and semi-volatile compounds with the associated FALs.

\subsubsection{Measurement and Analysis Sensitivity}

Samples may be field-screened to help identify the area of contamination; however, final decisions will be made based on samples that have been submitted for laboratory analysis. The measurement and analysis methods listed in the Industrial Sites QAPP (NNSA/NV, 2002) are capable of measuring analyte concentrations at or below the corresponding action levels for each constituent. Samples will be analyzed using the following analytical methods:

- $\quad$ TPH samples will be analyzed using EPA Method 8015B for TPH (EPA, 1996).

- $\quad$ VOC samples will be analyzed using EPA Method 8260B (EPA, 1996).

- $\quad$ SVOC samples will be analyzed using EPA Method 8270C (EPA, 1996).

\subsubsection{Specify Performance or Acceptance Criteria (Step 6)}

Step 6 of the DQO process specifies performance criteria for the decision rules. Setting tolerable limits on decision errors requires the planning team to weigh the relative effects of threats to human health and the environment, expenditure of resources, and the consequences of an 
Table 2. Chemical Components of Diesel and Associated FALs

\begin{tabular}{||c|c||}
\hline Chemical Compound & $\begin{array}{c}\text { FAL } \\
\text { (mg/kg) }\end{array}$ \\
\hline 1,3,5-Trimethylbenzene $^{1}$ & 70 \\
\hline 2-Methylnaphthalene $^{1}$ & 190 \\
\hline Anthracene & 100,000 \\
\hline Benz(a)anthracene & 2.1 \\
\hline Benzene & 1.4 \\
\hline Benzo(a)pyrene & 0.2 \\
\hline Benzo(b)fluoranthene & 21 \\
\hline Benzo(g,h,i)perylene & 29,000 \\
\hline Benzo(k)fluoranthene & 21 \\
\hline Chrysene & 210 \\
\hline Ethylbenzene & 400 \\
\hline Fluoranthene & 22,000 \\
\hline Fluorene & 26,000 \\
\hline Naphthalene & 190 \\
\hline n-Butylbenzene & 240 \\
\hline n-Propylbenzene & 240 \\
\hline Phenanthrene & 100,000 \\
\hline Pyrene & 29,000 \\
\hline Toluene & 520 \\
\hline Xylenes ${ }^{2}$ & 420 \\
\hline
\end{tabular}

${ }^{1}$ Uses PRG for napthalene

${ }^{2}$ Total of m-, o-, and p-xylenes

FAL - final action level

mg/kg - milligrams per kilogram

incorrect decision. This section provides an assessment of the possible outcomes of DQO decisions and the impact of those outcomes if the decisions are in error.

CAU 134 will be sampled using the judgmental sampling approach. The EPA DQO guidelines state that if a judgmental sampling approach is used, quantitative statements about data quality will be limited to measurement error (EPA, 2006). Measurement error is influenced by imperfections in the measurement and analysis system. Random and systematic measurement errors are introduced in the measurement process during physical sample collection, sample 
handling, sample preparation, sample analysis, and data reduction. If measurement errors are not controlled, they may lead to errors in making the DQO decisions.

In general, confidence in DQO decisions based on judgmental sampling results will be established qualitatively by:

- Developing CSMs

- Testing the validity of the CSMs based on investigation results

- Evaluating the quality of the data based on DQI parameters

\subsubsection{Decision Errors}

There is one CAU 134 baseline condition (i.e., null hypothesis) and an associated alternative condition for CAU 134, CASs 15-01-05 and 29-01-01. CAS 03-01-03 has no potential alternative condition because available information is adequate and supports the baseline condition. The baseline condition at CASs 03-01-03, 15-01-05, and 29-01-01 is that soil below the AST is not impacted at concentrations greater than the action level. The alternative condition at CASs 15-01-05 and 29-01-01 is that the soil has been impacted at concentrations above the action level by a release from the tank.

\subsection{False Rejection (False Positive) Decision Error}

This error would mean deciding that the baseline condition is false when, in fact, it is true. This error means deciding that the soil beneath the AST is contaminated at concentrations greater than the action level when it is not. The consequence of this decision is increased cost both for the closure effort and post-closure requirements that should not be needed. False positive errors are typically attributed to laboratory and/or sampling errors that could cause cross contamination. To control against cross contamination, disposable sampling equipment will be used and/or decontamination of sampling equipment will be conducted according to established and approved procedures, and only clean sample containers will be used.

\subsection{False Acceptance (False Negative) Decision Error}

This error would mean deciding that the baseline condition is true when, in fact, it is false. This error means deciding that the soil below the CAS 15-01-05 or CAS 29-01-01 AST (and/or at the original AST location at CAS 15-01-05) is not contaminated when, in fact, it is contaminated above action levels. The potential consequence is an increased risk to human health and the environment. This error will be controlled by meeting these criteria:

- Having a high degree of confidence that the selected sample locations will identify contamination if it is present. To satisfy this criterion, samples will be collected from below tank openings, which are the most likely locations for a release to have occurred. At CAS 29-01-01, a sample will be collected from where the staining has been observed.

- Having a high degree of confidence that the analyses conducted will be sufficient to detect any contamination present in the samples. To satisfy this criterion, the DQI of sensitivity will be assessed for all analytical results to ensure that all sample analyses had detection limits that were less than or equal to the corresponding action level.

- Having a high degree of confidence that the data set is of sufficient quality. To satisfy this criterion, the data will be assessed against the DQIs of precision, accuracy, comparability, 
and completeness, and the appropriate QC samples will be collected as defined in the Industrial Sites QAPP (NNSA/NV, 2002).

\subsubsection{Develop the Plan for Obtaining Data (Step 7)}

Step 7 of the DQO process provides the general approach for obtaining the information necessary to resolve the decisions. A judgmental sampling scheme will be implemented to select sample locations and evaluate analytical results for CASs 15-01-05 and 29-01-01. EPA's DQO guidelines state that a judgmental sampling approach can be used when there is sufficient information on the contamination sources and history to develop a valid CSM and to select specific sampling locations (EPA, 2006). This design is used to confirm the existence of contamination at specific locations and provide information about specific areas of the site. Sample locations for judgmental sampling will be determined based on process knowledge and visual observations.

For CAS 15-01-05, a minimum of one soil sample will be collected from below the AST, from the location(s) most likely to be impacted by a release from the tank. The Climax Mine area will also be checked for visual evidence of the original location of the AST. If the original location of the AST is found, then a minimum of one soil sample will be collected from that location. Samples will be collected from locations where there is visual evidence of a release, such as stained soil. In absence of visual evidence of a release, samples will be collected from below the tank opening that is lowest and most likely to have released fluid. This could be from below an open pipe or from below a rusted-through portion of the tank wall. Site visits have shown no indication of stained soil; however, the area will be evaluated again after the tank has been moved from its current location.

Samples collected from CAS 15-01-05 will be analyzed for TPH (gas-diesel-oil range) using EPA method 8015B (EPA, 1996). If TPH concentrations are less than the $100 \mathrm{mg} / \mathrm{kg}$ PAL, then no further action is needed. If TPH concentrations exceed $100 \mathrm{mg} / \mathrm{kg}$, then samples will be collected and analyzed for VOCs and SVOCs. Results will be compared against the FALs. If concentrations are less than FALs, then no further action is needed.

For CAS 29-01-01, a minimum of one soil sample will be collected from below the spigot at the north end of the AST, which is where staining has been observed. Samples will be analyzed for TPH (diesel-range) using EPA method 8015B (EPA, 1996). If TPH concentrations are less than the $100 \mathrm{mg} / \mathrm{kg}$ PAL, then no further action is needed. If TPH concentrations exceed $100 \mathrm{mg} / \mathrm{kg}$, then samples will be collected and analyzed for VOCs and SVOCs. Results will be compared against the FALs. If concentrations are less than FALs, then no further action is needed.

At either site, if contamination is present at concentrations greater than the FAL, then samples will be collected from surface and subsurface soil to bound the extent of contamination. Samples will only be analyzed for those VOC and/or SVOC compounds that exceeded the FAL. A minimum of three samples will be collected from surface soil (i.e., 0-6 inches below ground surface) to bound the extent of surface contamination. A minimum of one soil sample will be collected from soil located just above the soil-bedrock interface, at a location that is down slope of the surface contamination. Because of limited access and steeply sloped bedrock at these sites, the subsurface samples may be collected from some distance outside of the CAS 
boundaries. The intent is to confirm that the contamination has not migrated to surface drainages (e.g., dry washes or arroyos).

If contamination is found, the area of contamination greater than the FALs will be closed in place with implementation of a UR. Although clean closure is not planned because of the steep slopes, shallow bedrock, and remote location of these sites, this option may be taken if the extent of contamination is shown to be minimal and able to be excavated safely. To verify clean closure of the site, samples will be collected from the base and sides of the excavation to verify remaining levels are less than action levels. A minimum of (a) 1 sample from the base of the excavation and (b) 2 samples from the sidewall if the excavation is smaller than 1 -ft diameter, or 3 samples if the excavation is larger than 1-ft diameter will be collected. Samples will only be analyzed for those compounds that exceeded the FALs.

For CAS 03-01-03, process knowledge and field screening show that there has been no release of regulated substances from the tank; therefore, no soil samples will be collected. CAS 03-01-03 will be closed with no further action. As a BMP, the CAS 03-01-03 and 15-01-05 ASTs will be disposed of or otherwise dispositioned in accordance with applicable federal and state regulations.

The CAS 03-01-04 tank was used to store potable water; therefore, the tank and releases from this tank are not an environmental concern.

A flowchart of the closure decision pathway for CAS 15-01-05 is presented in Figure 8.

\subsection{Results OF THE DQO ANALySIS}

\subsubsection{ACtion LEVEl Determination AND BASIS}

The following action levels have been established for CAU 134:

- TPH: The PAL will be $100 \mathrm{mg} / \mathrm{kg}$, in accordance with Section 445A.2272 of the NAC (NAC, 1996).

- VOCs and SVOCs: FALs will be the PRGs for chemical constituents in industrial soil (EPA, 2004) for the individual chemical components of diesel, which are presented in Table 2.

If results show that chemical concentrations in the soil exceed the FALs, then a UR will be implemented for the site. 


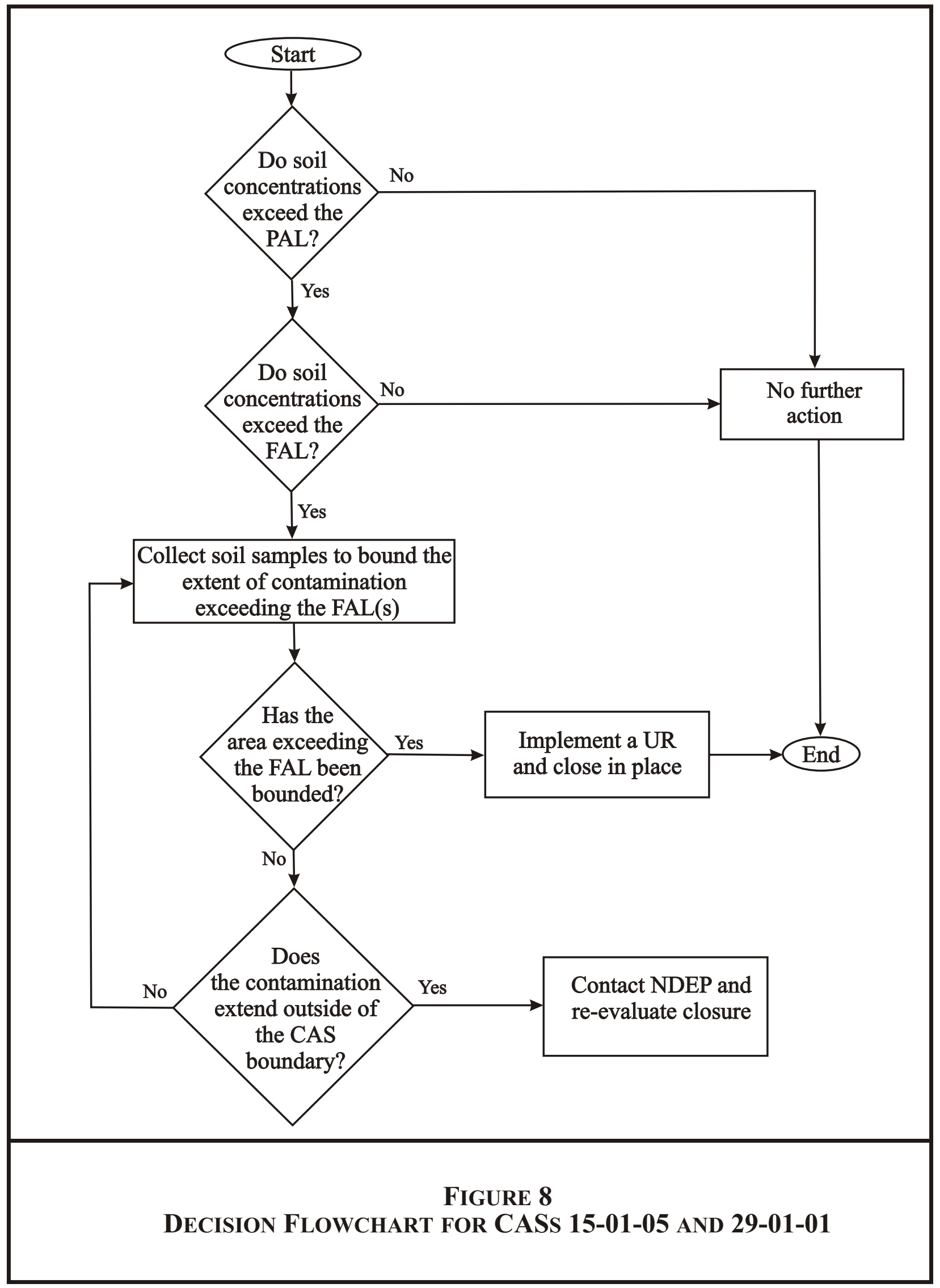




\subsubsection{HYPOTHESIS TEST}

Only valid data from laboratory analytical results will be used to determine if contamination is present. The null hypothesis is that soil below the ASTs at CASs 15-01-05 (including the original tank location) and 29-01-01 is not impacted at concentrations above action levels. The two types of decision errors are false positive and false negative.

A false positive decision error would occur if contamination is determined to be present above the action level when, in actuality, it is not. This would result in increased costs for unnecessary sample collection and analysis and post-closure costs.

A false negative decision error would occur if contamination is determined to not be present above the action level when, in actuality, it is present. If the area with contaminated soil is not identified, it would result in an increased risk to human health by leaving the impacted soil in place without identifying the hazard through a UR.

\subsubsection{Statistical Model}

Individual sample results will be compared to action levels, and statistical models will not apply for determining the actions at the CAU 134 CASs. CASs 15-01-05 and 29-01-01 will be sampled at locations most likely impacted by releases from the tanks, as determined through biasing factors at the site.

\subsubsection{DESIGN DESCRIPTION/OPTION}

Biased (judgmental) samples will be collected from below the ASTs at CASs 15-01-05 and 29-01-01 and, if the original AST location is identified, from the original AST location at CAS 15-01-05. Sample locations will be chosen based on biasing factors observed at the time of sample collection and historical reports of staining (for CAS 29-01-01). If analytical results show that the action level has been exceeded, then a minimum of three step-out surface samples will be collected to bound the extent of surface contamination, and a minimum of one subsurface sample will be collected to bound the extent of subsurface migration of contamination. If these sites are remediated, then verification samples will be collected to confirm clean closure. Verification samples will consist of a minimum of (a) 1 sample from the base of the excavation and (b) 2 samples from the sidewall if the excavation is smaller than 1-ft diameter, or 3 samples if the excavation is larger than 1-ft diameter.

\section{$3.2 .5 \mathrm{CSM}$}

One Primary CSM, with one Alternate CSM, is presented for the CAU 134 CASs. The primary CSM for CAS 03-01-03 and CAS 15-01-05 assumes that the ASTs did not release their contents to the environment. It is supported at CAS 03-01-03 by process knowledge and radiological screening of the tank and surrounding area. The primary CSM for CAS 29-01-01 assumes that diesel fuel was released to the environment. It is supported by minor soil staining under the spigot. The alternate CSM for CAS 15-01-05 assumes the contents (some or all) have been released to the environment. Because the CAS 15-01-05 AST does not appear to have been operational in its current location, a release from this AST should have resulted in a localized release of a limited volume to the surface soil, with limited migration into the subsurface soil. The alternate CSM for CAS 29-01-01 assumes the AST did not release its contents to the environment. The primary and alternate CSMs for these CASs are presented in Figures 3 and 4. 
CAU 134 Closure Report

Section: Appendix B

Revision: 0

Date: June 2009

\section{APPENDIX B}

\section{SAMPLE ANALYTICAL RESULTS}


CAU 134 Closure Report

Section: Appendix B

Revision: 0

Date: June 2009

THIS PAGE INTENTIONALLY LEFT BLANK 


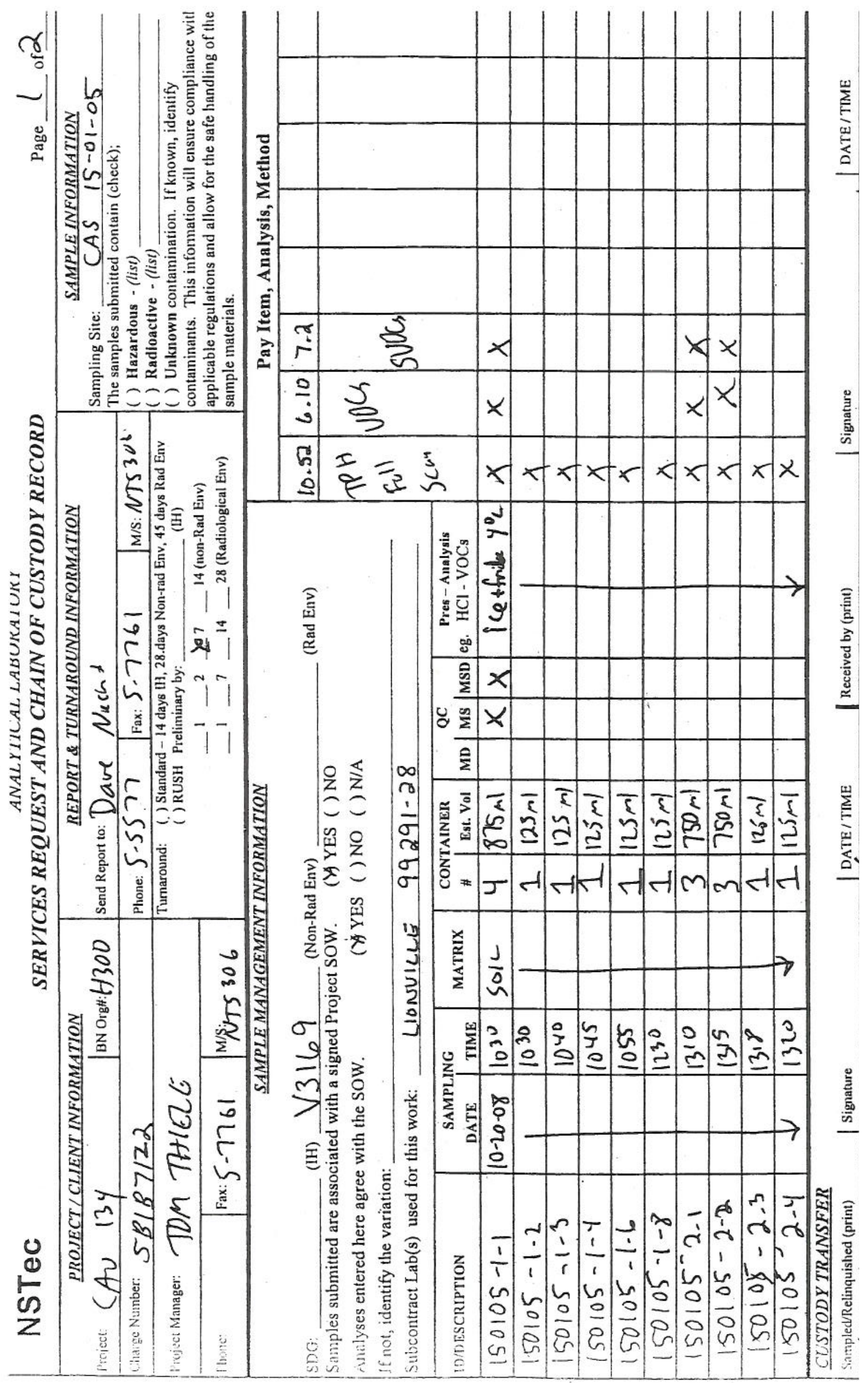




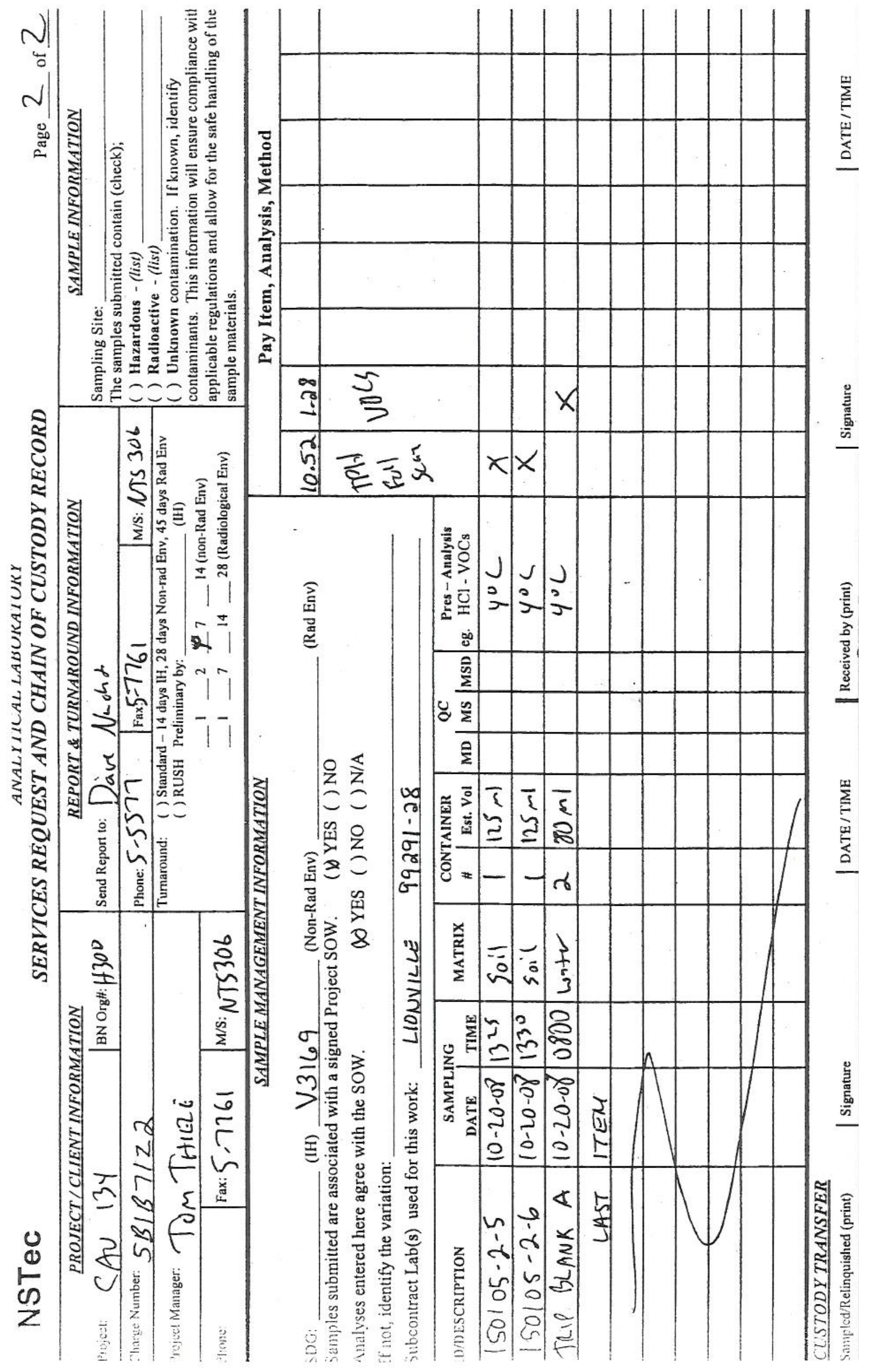




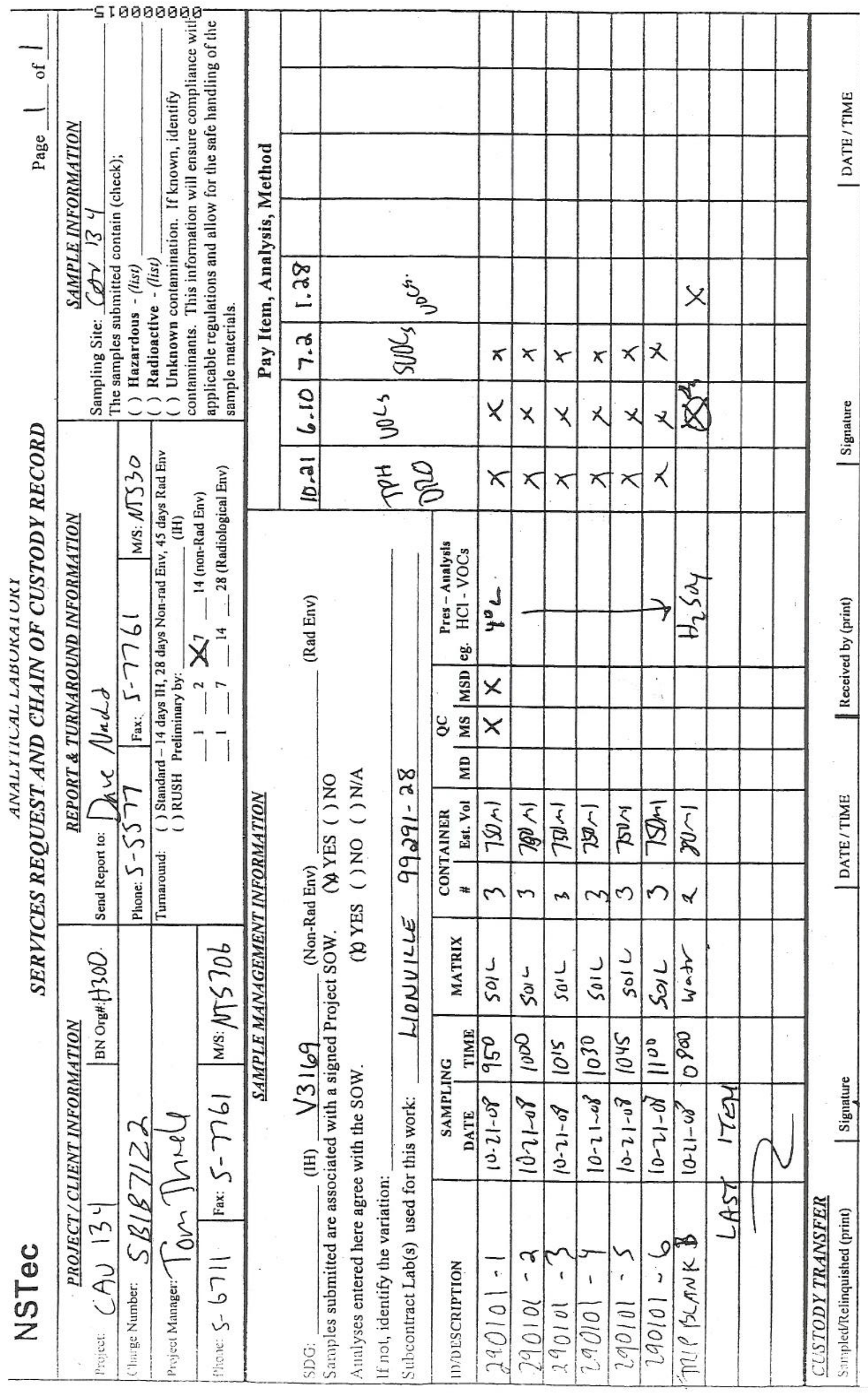




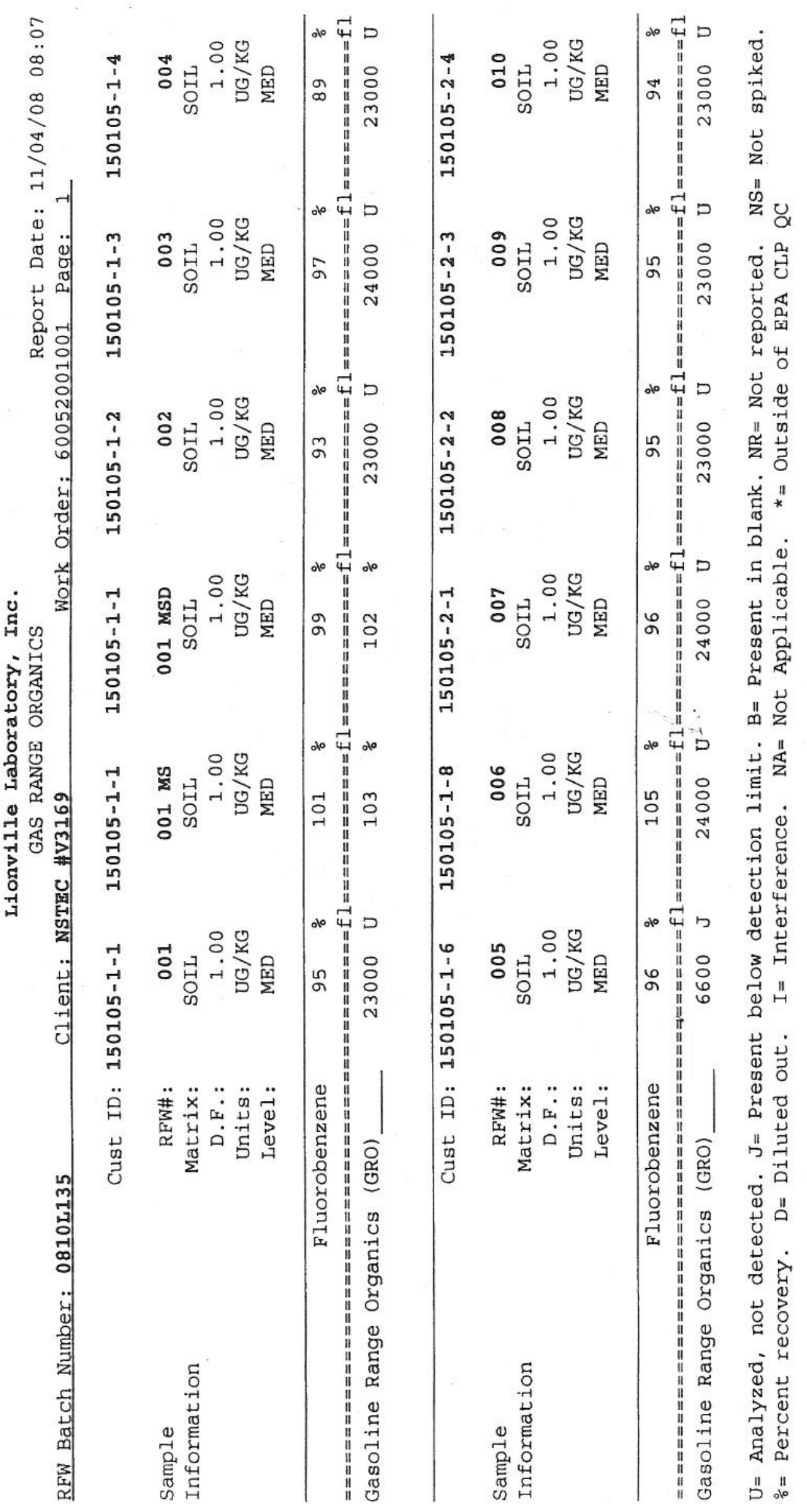


งเดอดดดตด

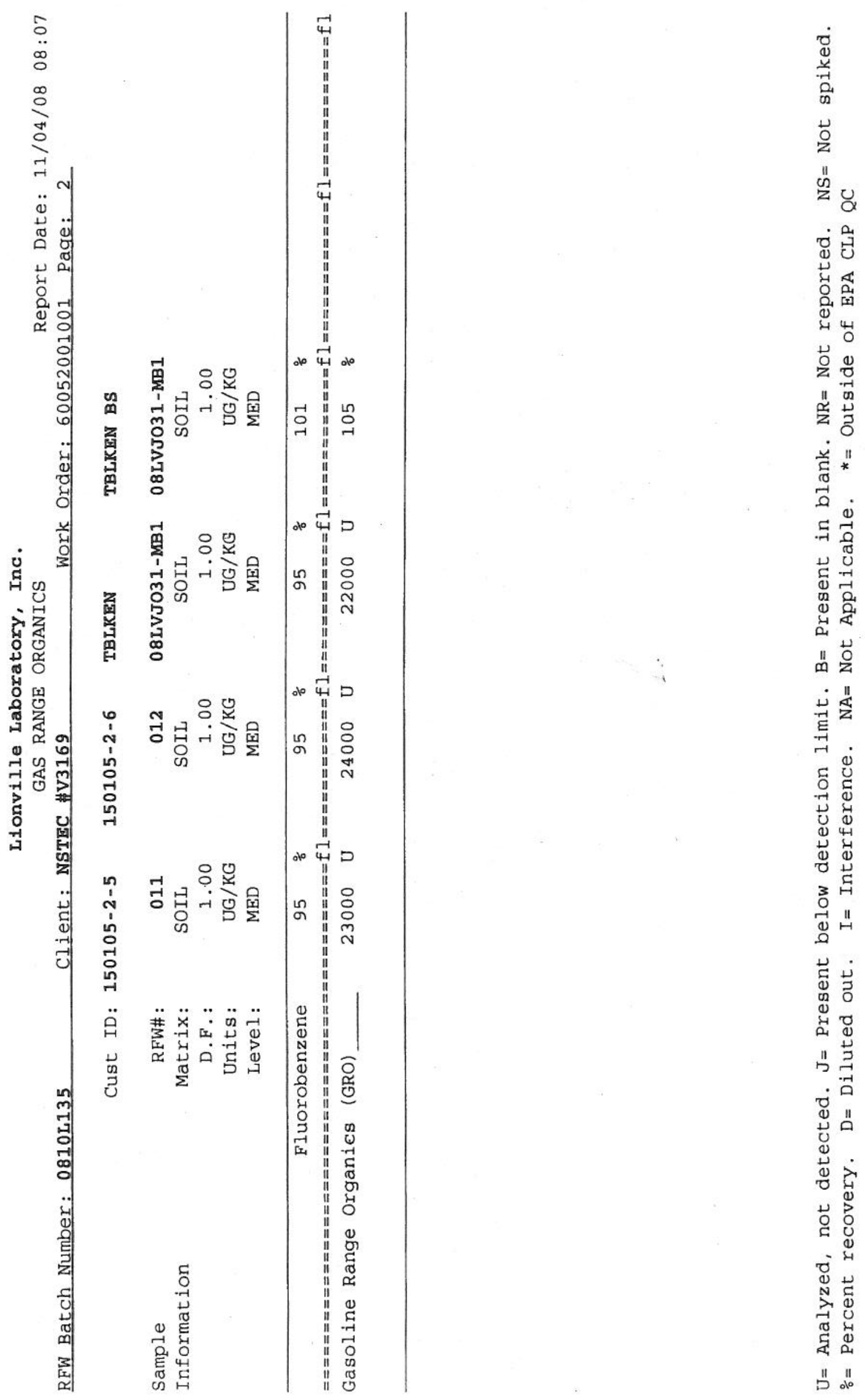




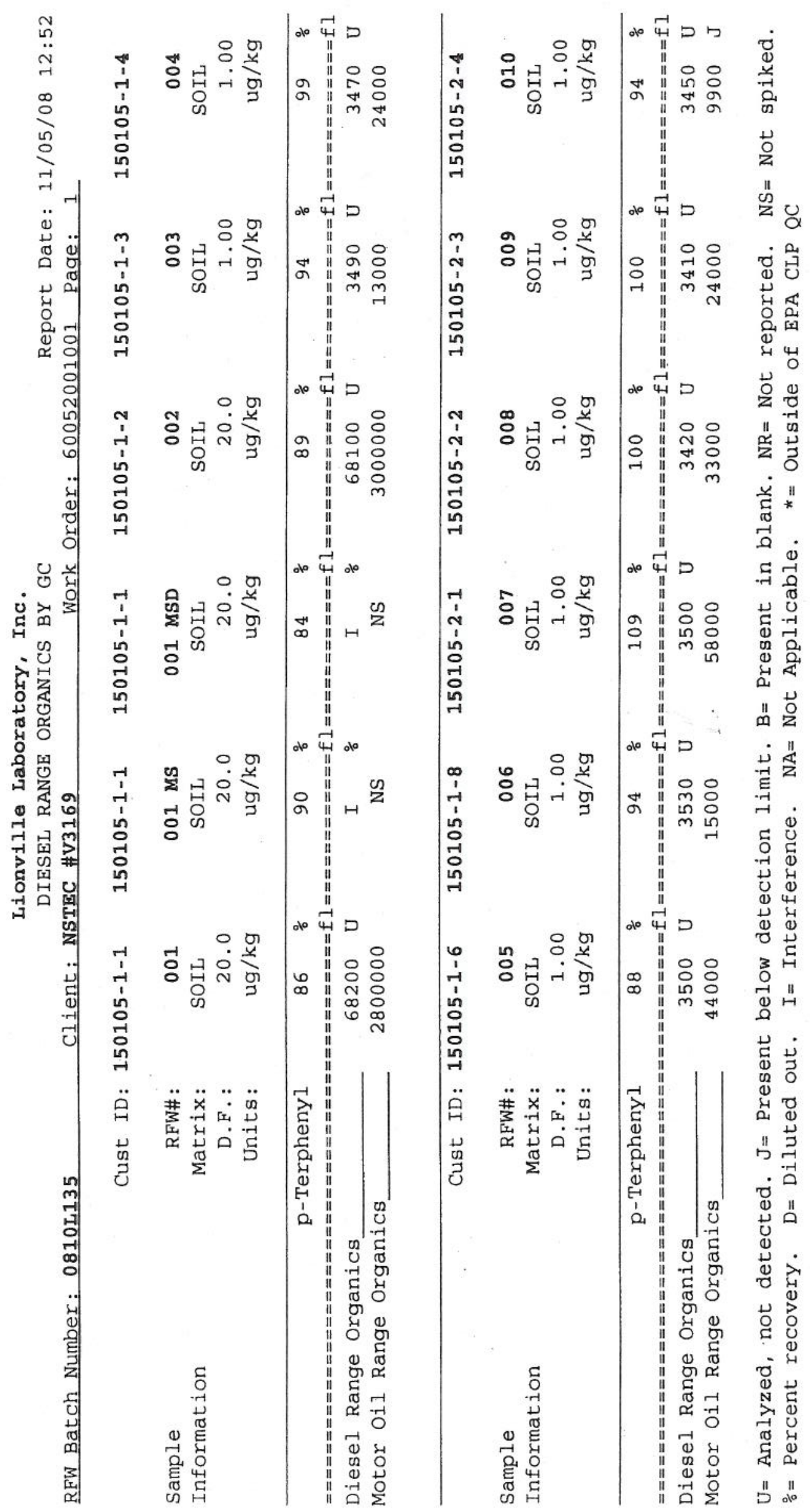




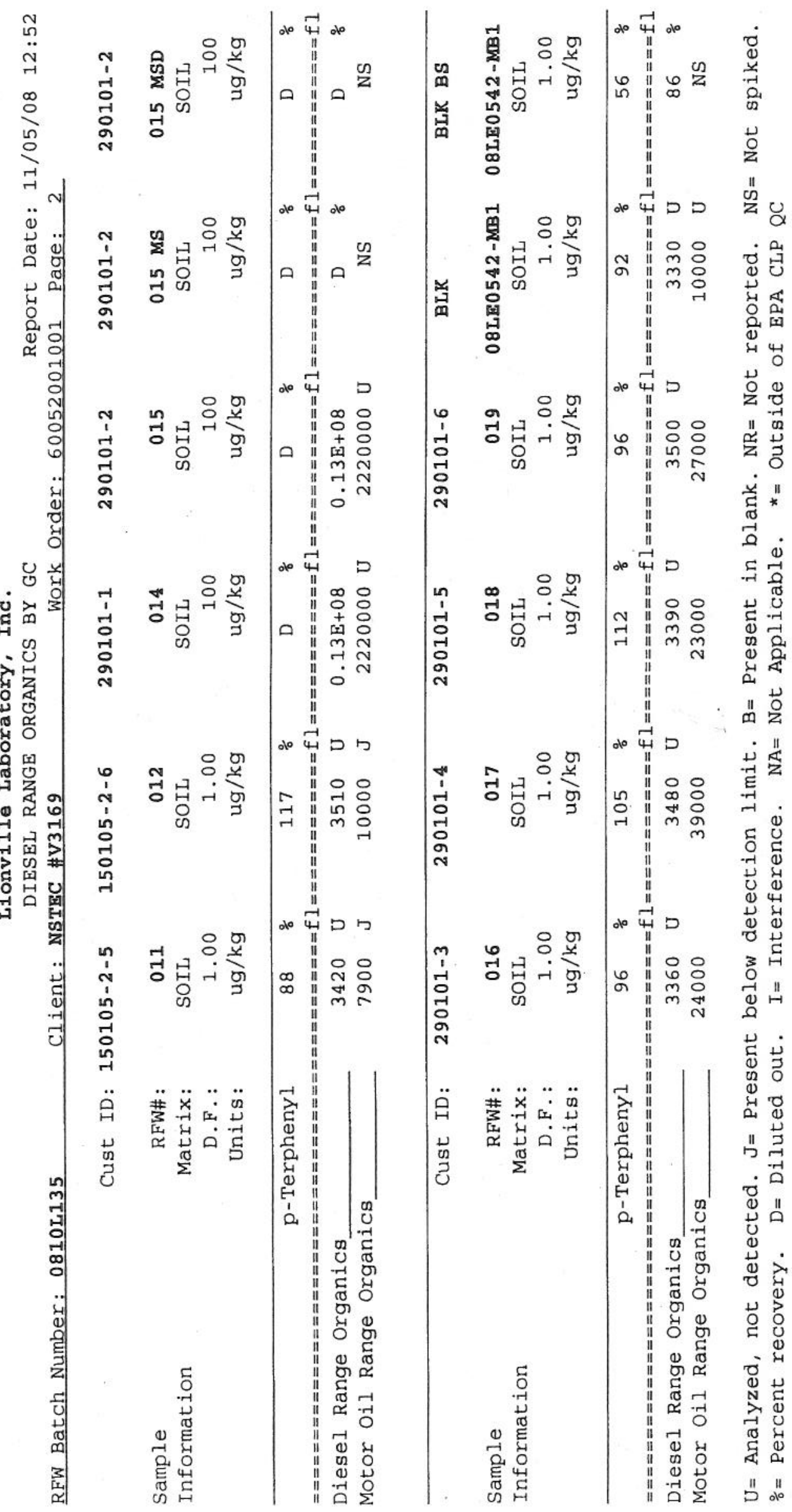




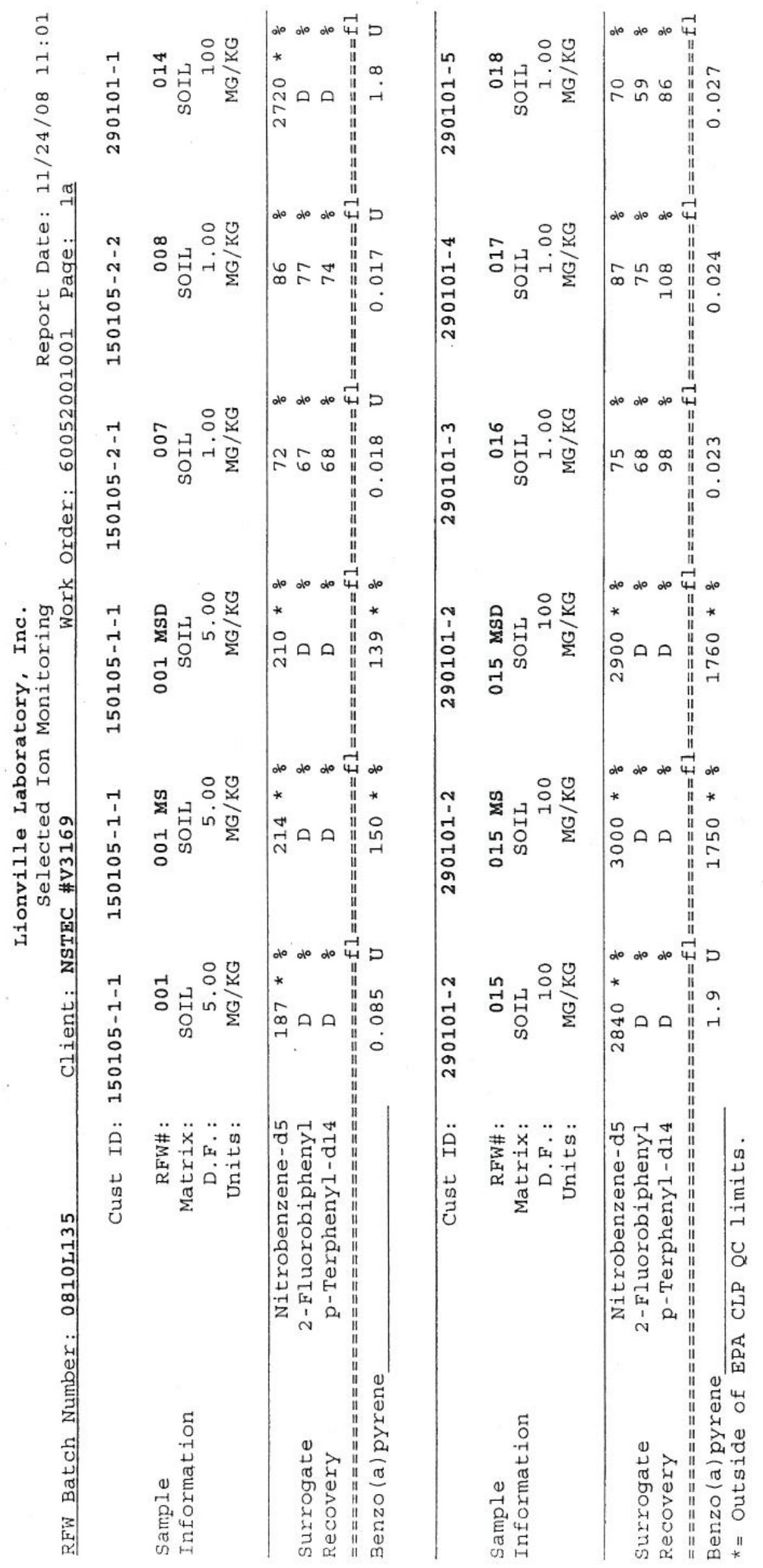




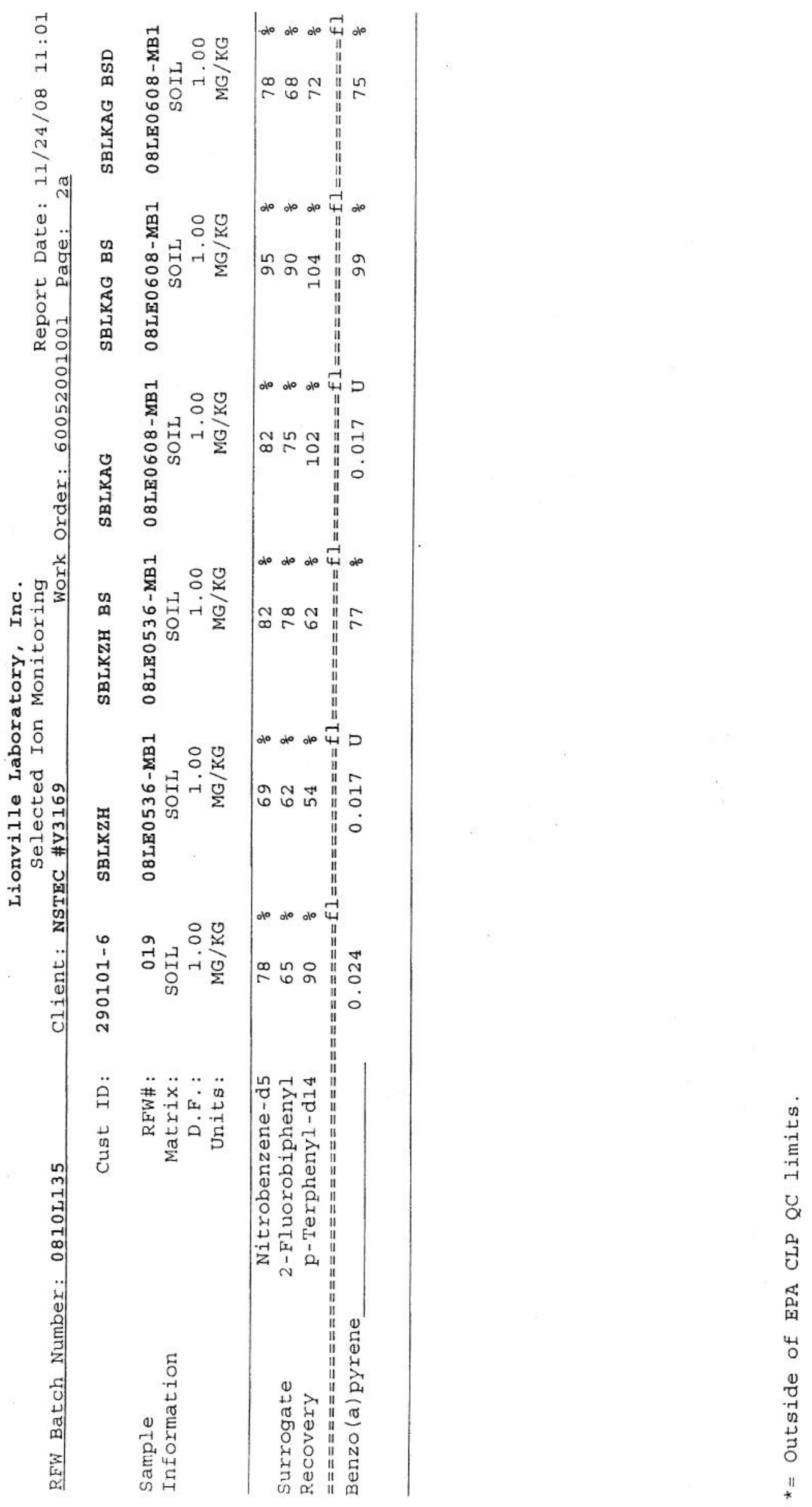




\section{8นดดอดอดด}

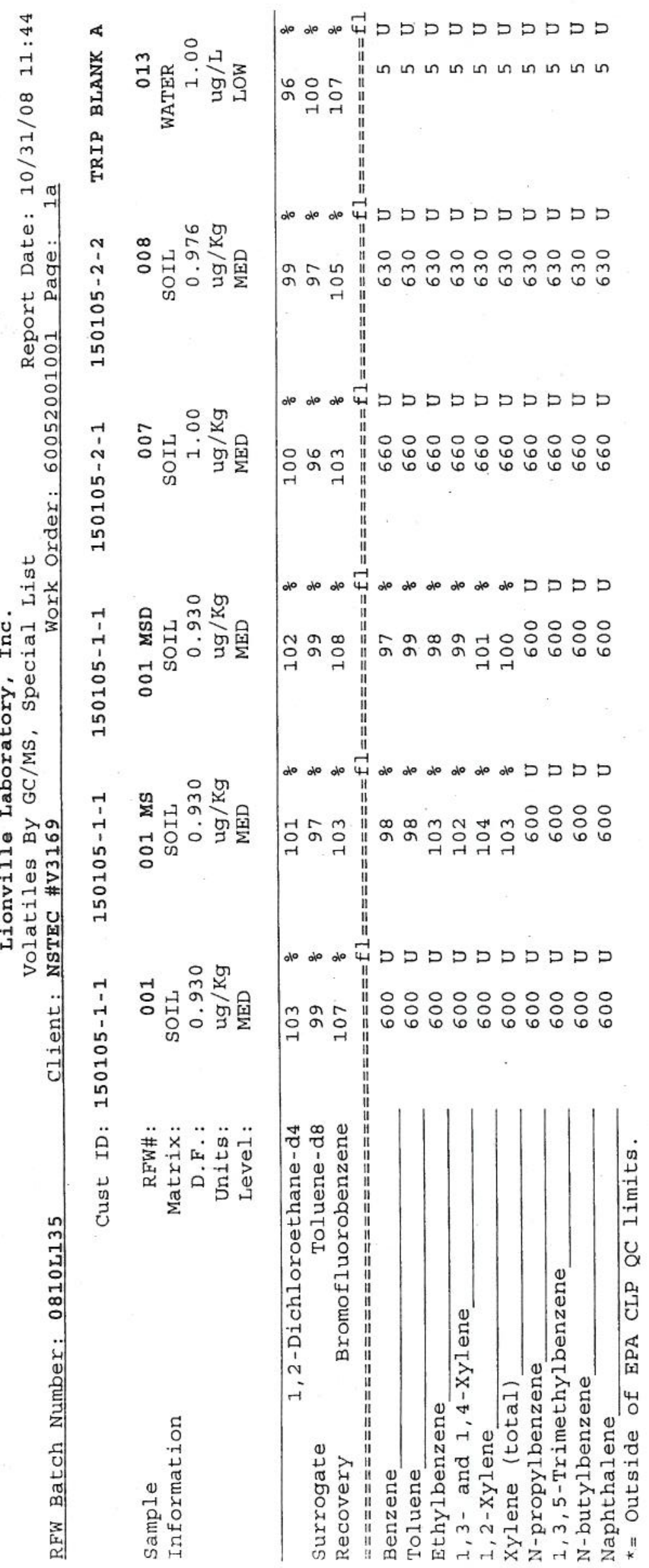


6รดดดดดดด

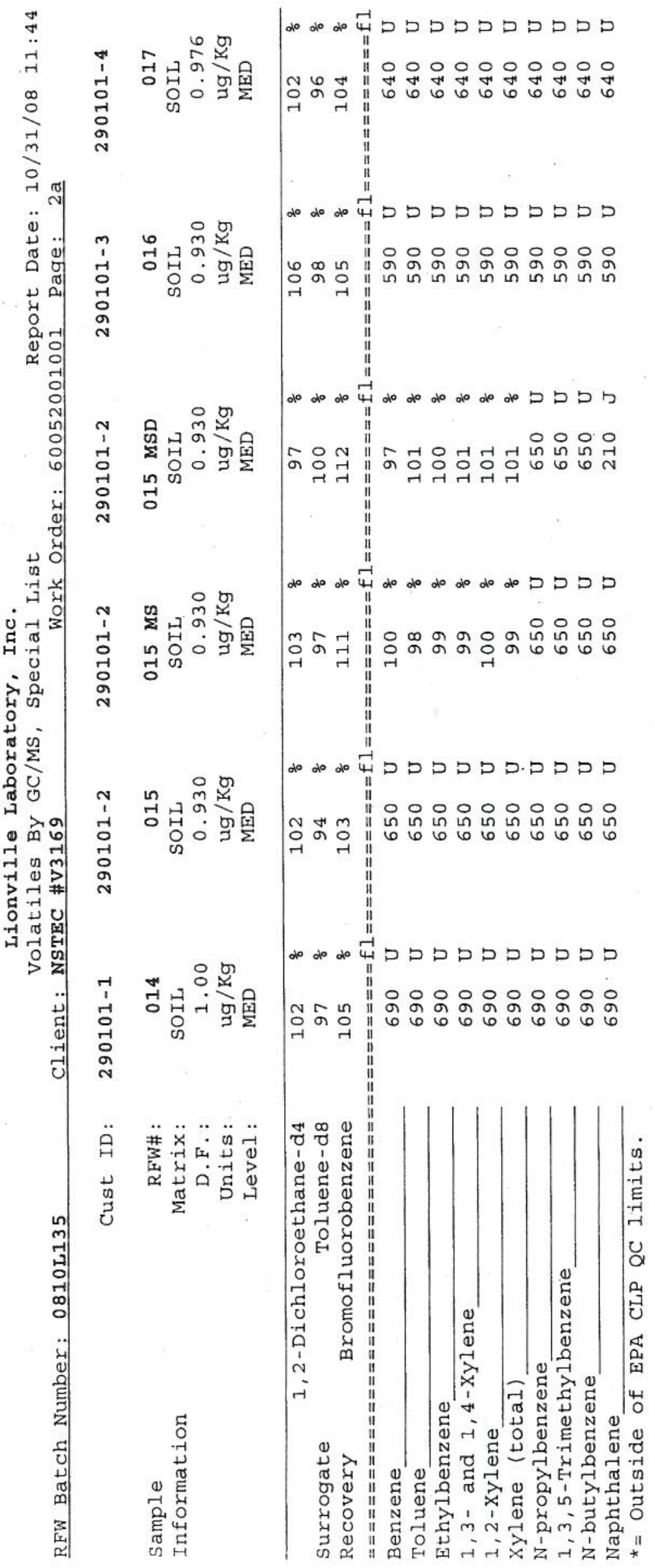




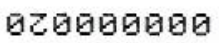

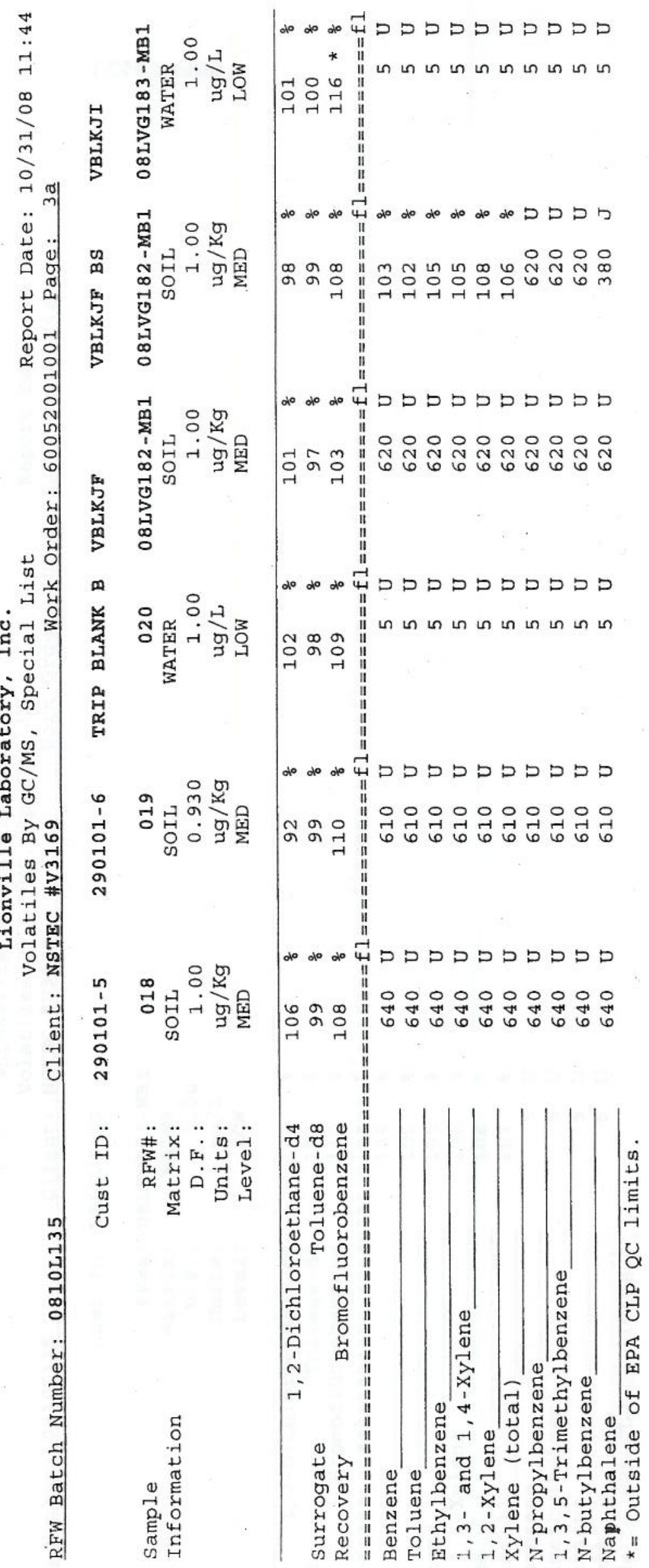


รวดอดดตัด

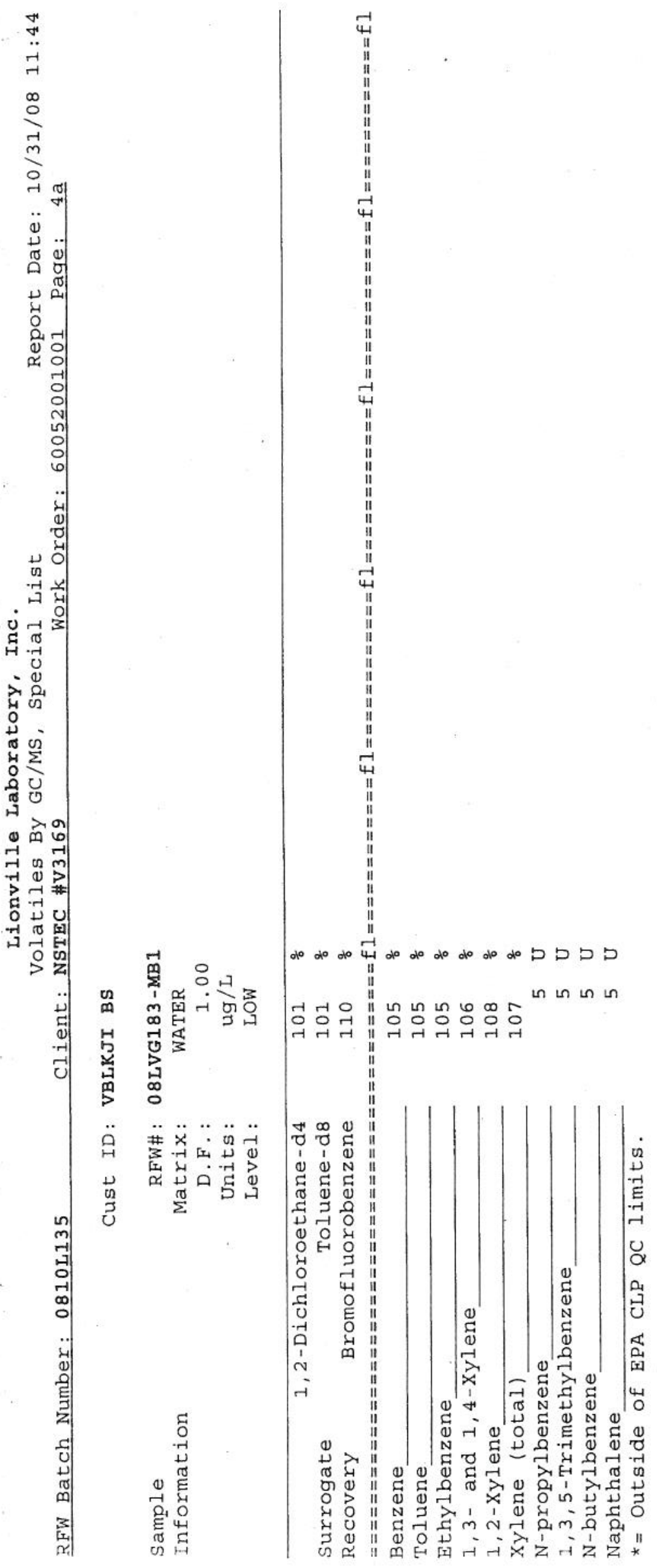


6รด0ด0905

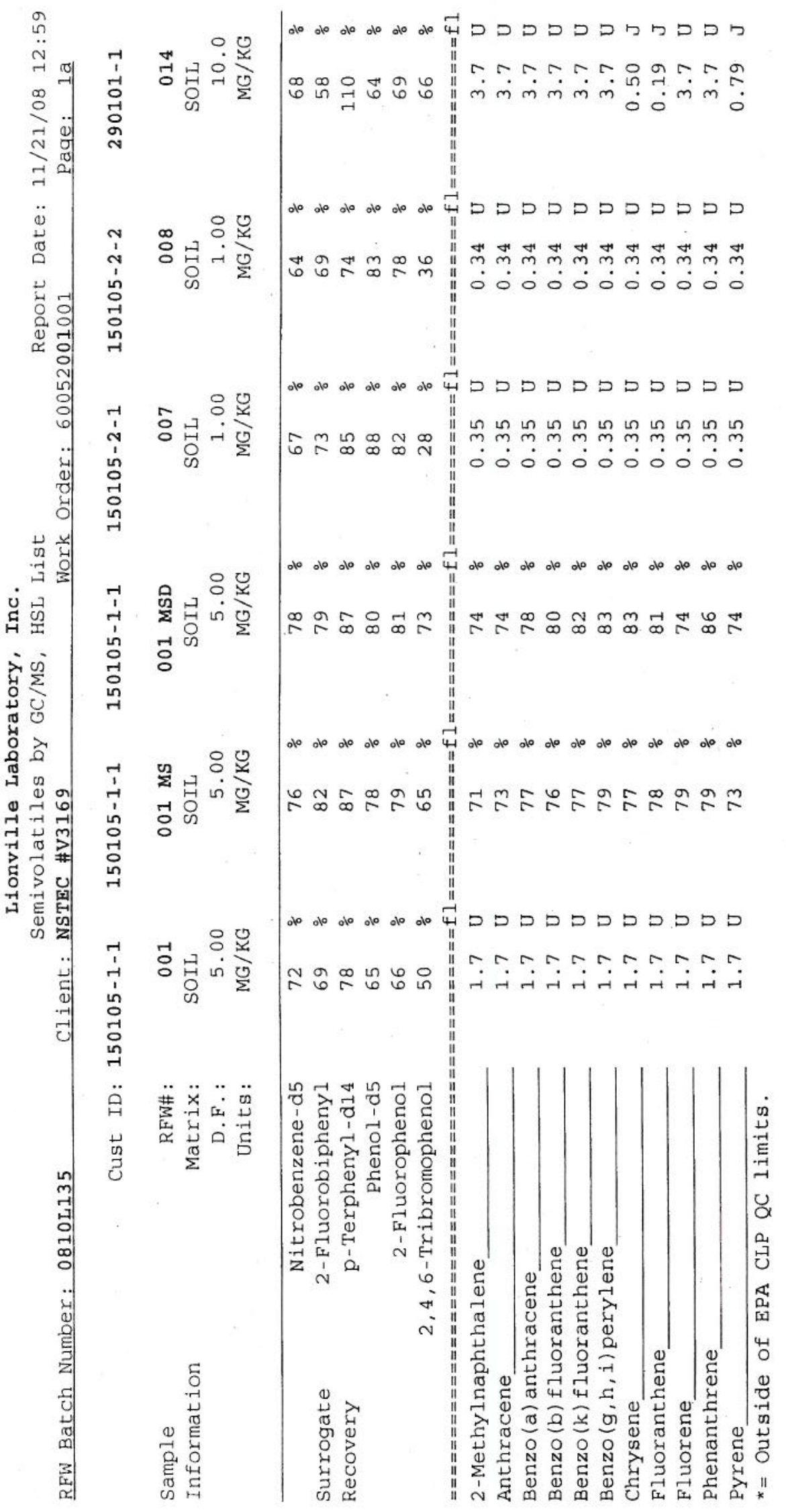


ดzog日日a日g

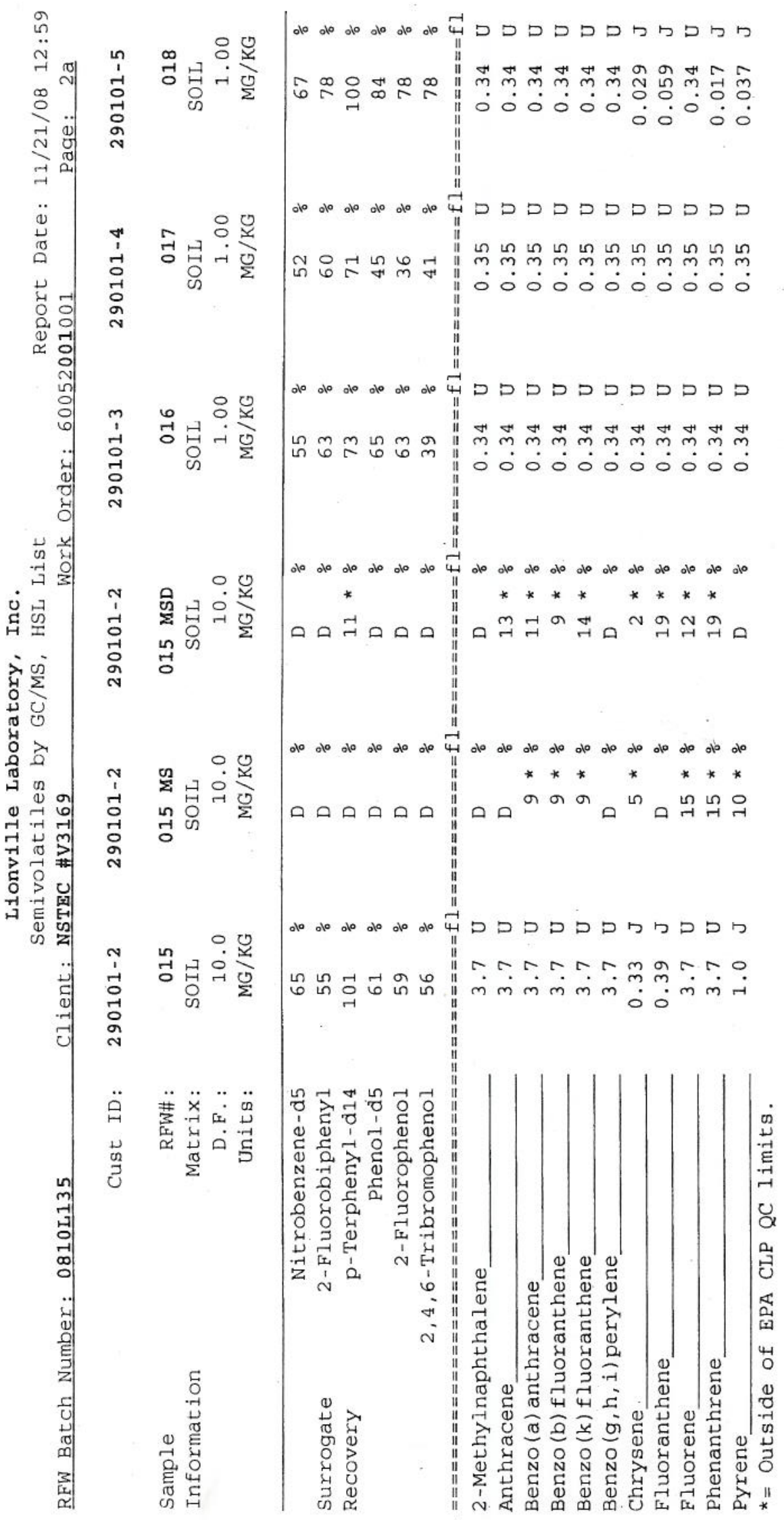


г200900ดด

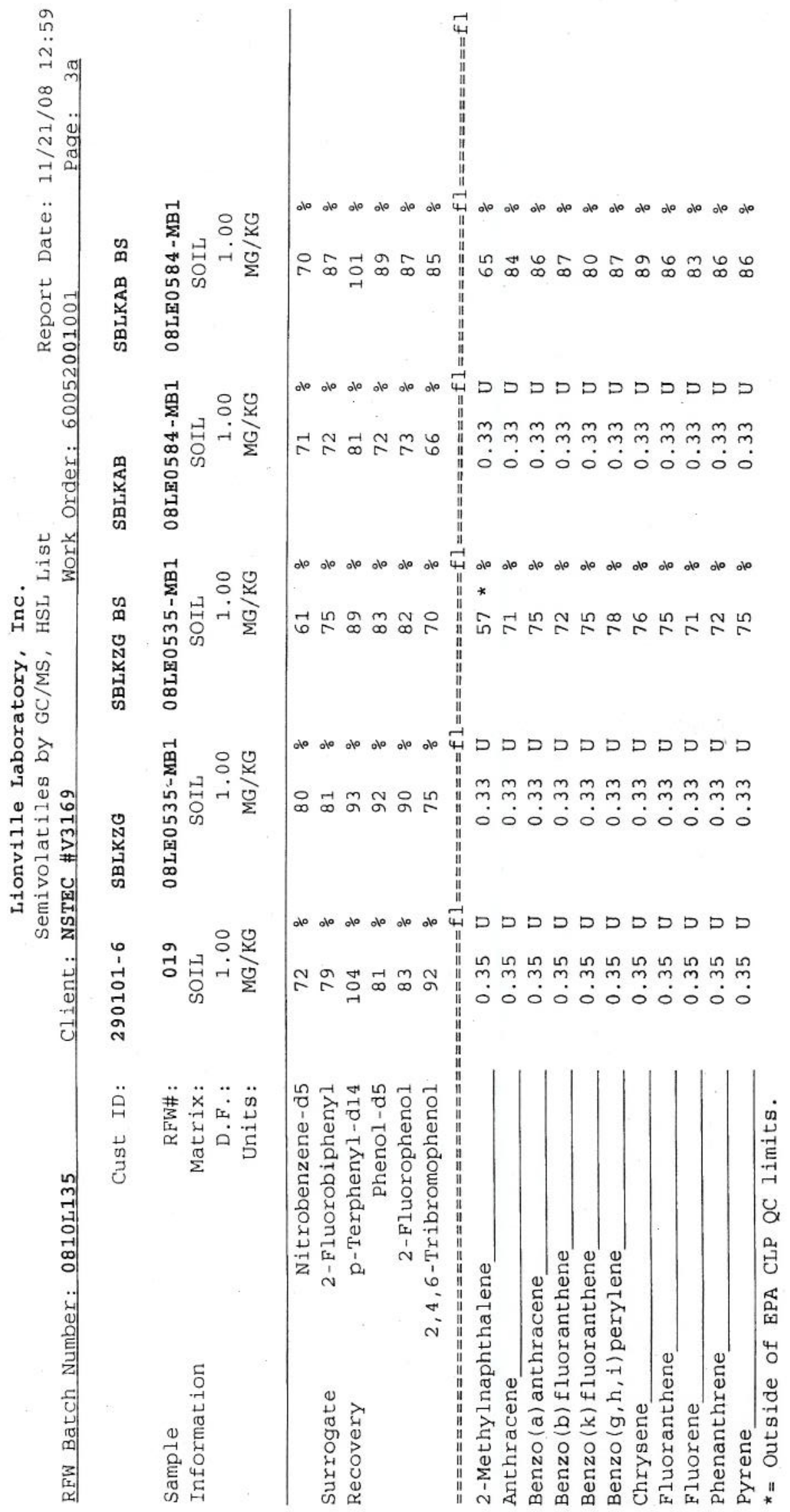




\section{NSTEC V3169 0810L135}

\section{PAH Analyses}

Samples were analyzed by method $8270 \mathrm{C}$ for PAHs and by $8270 \mathrm{C}$ Selected Ion Monitoring (SIM) for benzo(a)pyrene.

Samples 290101-1 and 290101-2 required a 10-fold instrument dilution for the standard $8270 \mathrm{C}$ runs and 100-fold dilutions for the SIM runs due to matrix interferences. (Refer to the case narratives and Sample Discrepancy Reports in the original data packages.)

The MDLs and Reporting Limits for a clean sample/blank meet your Final Action Limits for benzo(a)anthracene and benzo(a)pyrene However, when corrected for the dilution factors and for moisture, the sample-specific reporting limits are above the FALs. The MDLs adjusted for the sample dilutions would meet the FALs, and if the compounds were observed in the chromatogram above the MDL and the spectra matched the standard, they would typically be reported as estimated values (J flag) down to the adjusted MDL 


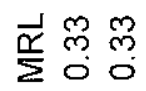

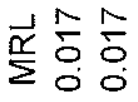

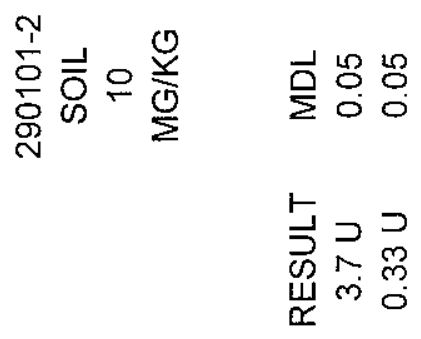

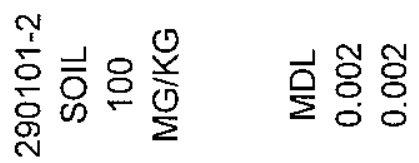

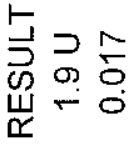

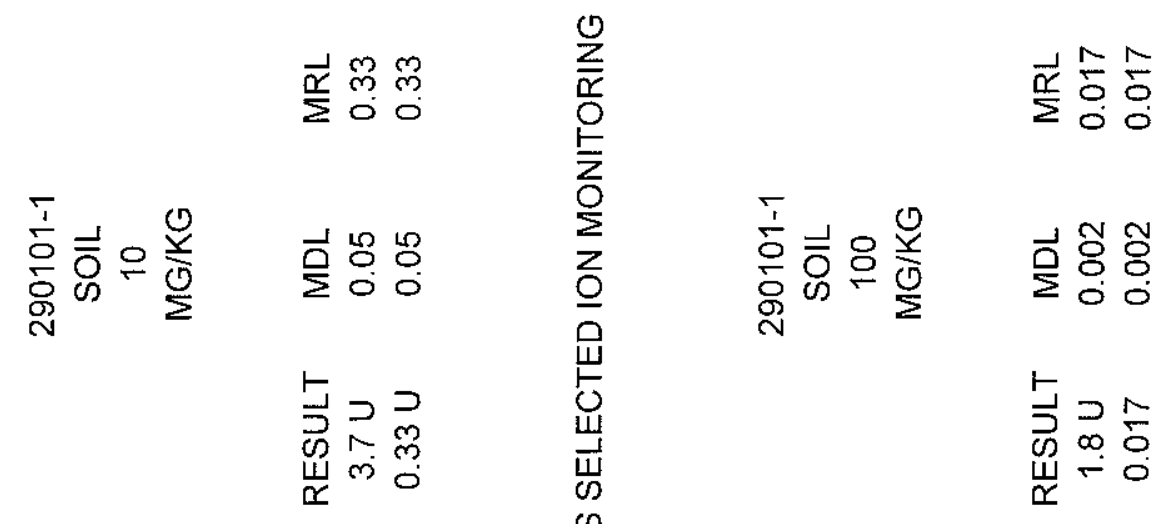

$\sum_{0}^{\infty}$
0
$⿱ 0$

崖

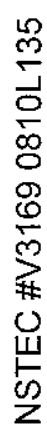

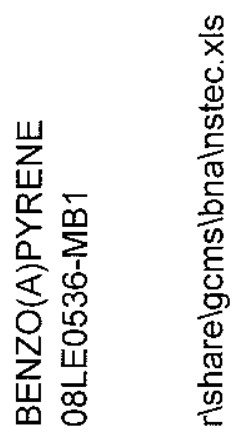


Revision: 0

Date: June 2009

\section{APPENDIX C}

WASTE DISPOSITION DOCUMENTATION 
CAU 134 Closure Report

Section: Appendix C

Revision: 0

Date: June 2009

THIS PAGE INTENTIONALLY LEFT BLANK 


\section{Form}

\begin{tabular}{|llllll}
\hline SWO USE (Select One) & AREA & $\square 23$ & $\square 6$ & QR & LANDFILL \\
\hline
\end{tabular}

For waste characterization, approval, and/or assistance, contact Solid Waste Operation (SWO) at 5-7898. REQUIRED: WASTE GERERATOR INFORMATION

(This form is for rolloffs, dump trucks, and other onsite disposal of materials.)

Waste Generator: MIKE FLOYD Phone Number: 295-6653

\section{Location / Origin: ARA -3 CPUC-13\%}

\begin{tabular}{|c|c|c|c|c|}
\hline \multicolumn{2}{|c|}{ Waste Category: (check one) } & \multirow{2}{*}{$\begin{array}{l}\square \text { Commercial } \\
\square \text { Putrescrible }\end{array}$} & \multicolumn{2}{|l|}{ Industrial } \\
\hline Waste Type: & $\triangle N T S$ & & $\triangle$ FFACO-onsite & $\square$ WAC Exception \\
\hline (check one) & $\square$ Non-Putrescible & $\square$ Asbestos Containing Material & $\square$ FFACO-offsite & $\square$ Historic DOE/NV \\
\hline \multicolumn{2}{|c|}{ Pollution Prevention Category: (check one) } & $\otimes$ Environmental management & $\square$ Defense Projects & $\square$ YMP \\
\hline \multicolumn{2}{|c|}{ Pollution Prevention Category: (check one) } & $\triangle$ Clean-Up & $\square$ Routine & \\
\hline \multicolumn{2}{|c|}{ Method of Characterization: (check one) } & $\triangle$ Sampling \& Analysis & $\triangle$ Process K & ts \\
\hline
\end{tabular}

Prohibited Waste at all three Radioactive waste; RCRA waste; Hazardous waste; Free liquids, PCBs above TSCA regulatory NTS landfills:

Additional Prohibited Waste at the Area 9 U10C Landfill:

\section{levels, and Medical wastes (needles, sharps, bloody clothing).}

Sewage Sludge, Animal carcasses, Wet garbage (food waste); and Friable asbestos

\section{REQUIRED: WASTE CONTENTS ALLOWABLE WASTES}

Check all allowable wastes that are contained within this load:

NOTE: Waste disposal at the Area 6 Hydrocarbon Landfill must have come into contact with petroleum hydrocarbons or coolants, such as: gasoline (no benzene, lead); jet fuel; diesel fuel; lubricants and hydraulics; kerosene; asphaltic petroleum hydrocarbon; and ethylene glycol.

Acceptable waste at any NTS landfill: $\square$ Paper
$\square$ Asphalt
$\bigotimes$ Metal
$\square$ Wood
$\square$ Soil
$\square$ Rocks / unaltered geologic materials
$\square$ Rubber (excluding tires)
$\square$ Insulation (non-Asbestosform)
Plastic $\square$ Wire $\quad \square$ Cable $\quad \square$ Cloth

$\bigotimes$ Empty containers
$\square$ Demolition debris
$\square$ Cement \& concrete

Manufactured items: (swamp coolers, furniture, rugs, carpet, electronic components, PPE, etc.)

Additional waste accepted at the Area 23 Mercury Landfill: $\square$ Office Waste $\square$ Food Wa
$\square$ Asbestos $\square$ Friable $\quad \square$ Non-Friable (contact SWO if regulated load) Quantity:

Additional waste accepted at the Area 9 U10c Landfill:
$\square$ Non-friable asbestos
$\square$ Drained automobiles and military vehicles
Light ballasts (contact SWO)
Hydrocarbons (contact SWO)
Drained fuel filters (gas \& diesel)
Other

Solid fractions from sand/oil/water

Deconned Underground and Above Ground Tanks

Additional waste accepted at the Area 6 Hydrocarbon Landfill:
$\square$ Septic sludge
$\square$ Rags
$\square$ Drained fuel filters (gas \& diesel)
Plants
Soil
$\square$ Sludge from sand/oil/water separatnrc REQUIRED: WASTE GENERATOR

Initials: (if initialed, no radiological clearance is necessary.)

The above mentioned waste was generated outside of a Controlled Waste $\mathrm{N}$ knowledge, does not contain radiological materials.

To the best of my knowledge, the waste described above contains only tho: site. I have verified this through the waste characterization method identifi prohibited and allowable waste items. I have contacted Property Managem is approved for disposal in the landfill.

Print Name: MIKE FLOYD

Signature: /s/ M Floyd
Date: 14,108
Crushed non-teme plated oil filters

$\sqcap$ Pr.Rs helow 50 varts der million

Radiological Survey Release for Waste Disposal RCT Initials

This container/load meets the criteria for no added man-made radioactive material This container/load meets the criteria for Radcon Manual Table 4.2 release limits. This container/load is exempt from survey due to process knowledge and origin.

SIGNATURE: DATE: $12-1-05$ BN-0646(10/05)

Note: "Food waste, office trash and animal carcasses do not require a radiological clearance. Freon-containing appliances must have signed removal certification statement with Load Verification."

SWO USE ONLY

Load Weight (net from scale or estimate)

$$
12 / 2 / 08
$$

Signature of Certifier: /s/ Don Bickford 
CAU 134 Closure Report

Section: Appendix C

Revision: 0

Date: June 2009

THIS PAGE INTENTIONALLY LEFT BLANK 
CAU 134 Closure Report

Section: Appendix D

Revision: 0

Date: June 2009

APPENDIX D

\section{SITE CLOSURE PHOTOGRAPHS}


CAU 134 Closure Report

Section: Appendix D

Revision: 0

Date: June 2009

THIS PAGE INTENTIONALLY LEFT BLANK 
Photograph Log

\begin{tabular}{|c|c|c|l||}
\hline $\begin{array}{c}\text { PHOTOGRAPH } \\
\text { NuMBER }\end{array}$ & \multicolumn{1}{|c||}{ DATE } & $\begin{array}{c}\text { CORRECTIVE } \\
\text { ACTION SITE }\end{array}$ & \multicolumn{1}{||}{ DESCRIPTION } \\
\hline \hline 1 & $10 / 25 / 2007$ & $03-01-03$ & Tank before Removal \\
\hline 2 & $10 / 16 / 2008$ & $03-01-03$ & Opening Tank to Verify Empty \\
\hline 3 & $10 / 20 / 2008$ & $15-01-05$ & Sampling at Original Tank Location \\
\hline 4 & $10 / 20 / 2008$ & $15-01-05$ & Sampling at Current Tank Location \\
\hline 5 & $10 / 21 / 2008$ & $29-01-01$ & Sampling beneath Tank Spigot \\
\hline 6 & $12 / 01 / 2008$ & $03-01-03$ & Removal of Tank using Crane \\
\hline 7 & $12 / 02 / 2008$ & $03-01-03$ & Disposal of Tank at Landfill \\
\hline 8 & $12 / 10 / 2008$ & $03-01-03$ & Grouting Tank at Landfill \\
\hline
\end{tabular}


CAU 134 Closure Report

Section: Appendix D

Revision: 0

Date: June 2009

\section{THIS PAGE INTENTIONALLY LEFT BLANK}




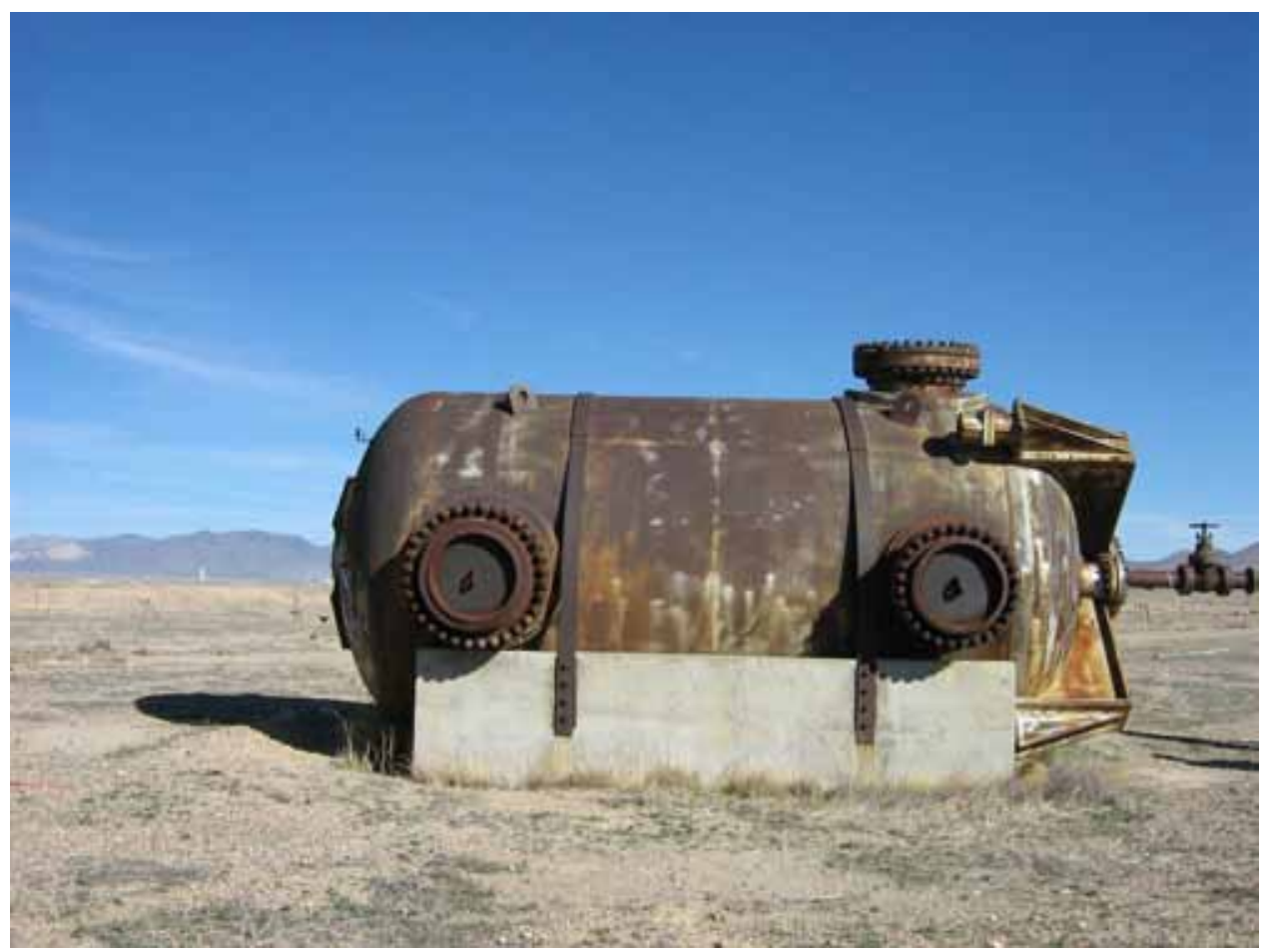

Photograph 1: CAS 03-01-03, Tank before Removal, 10/25/2007

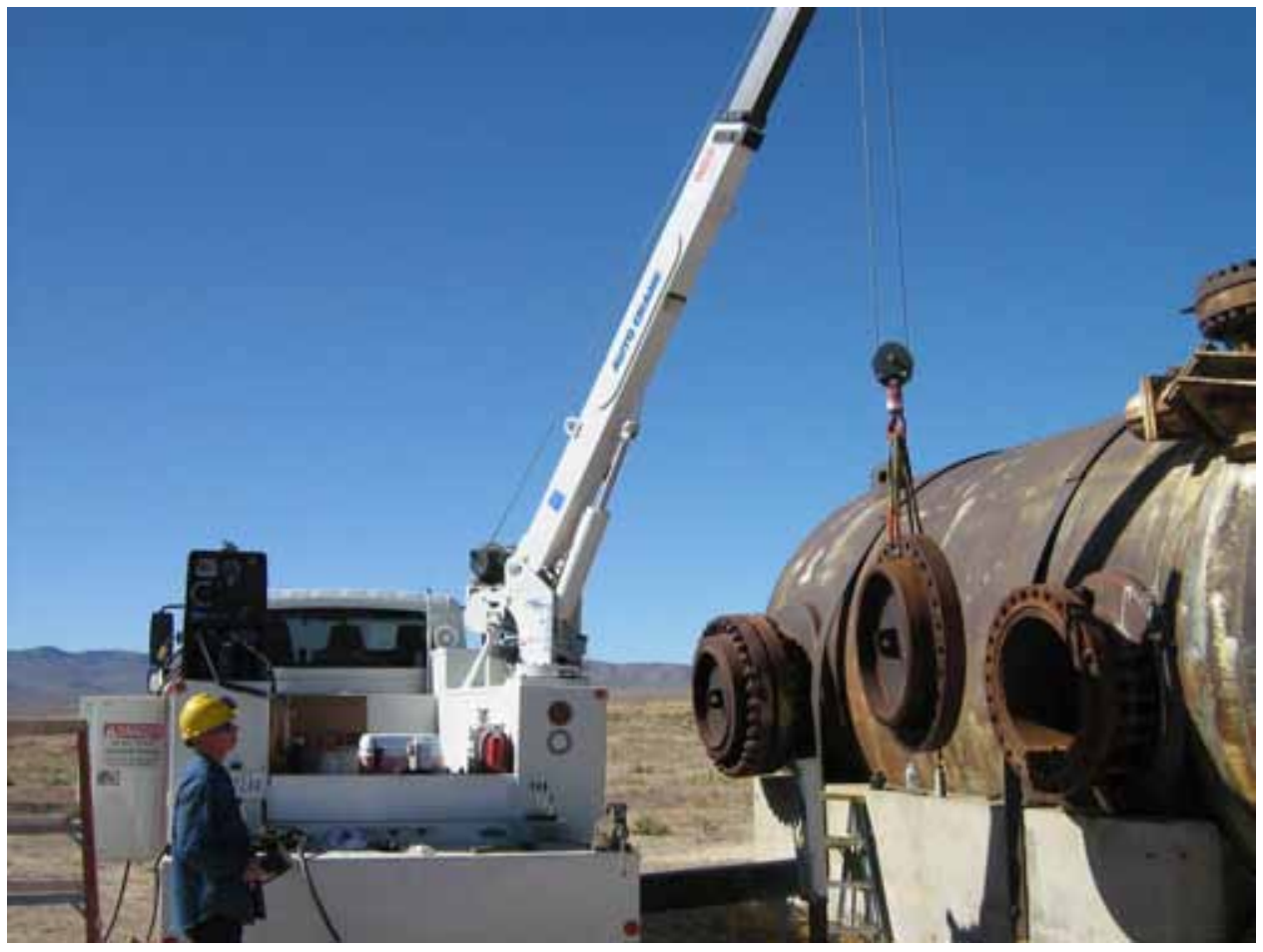

Photograph 2: CAS 03-01-03, Opening Tank to Verify Empty, 10/16/2008 


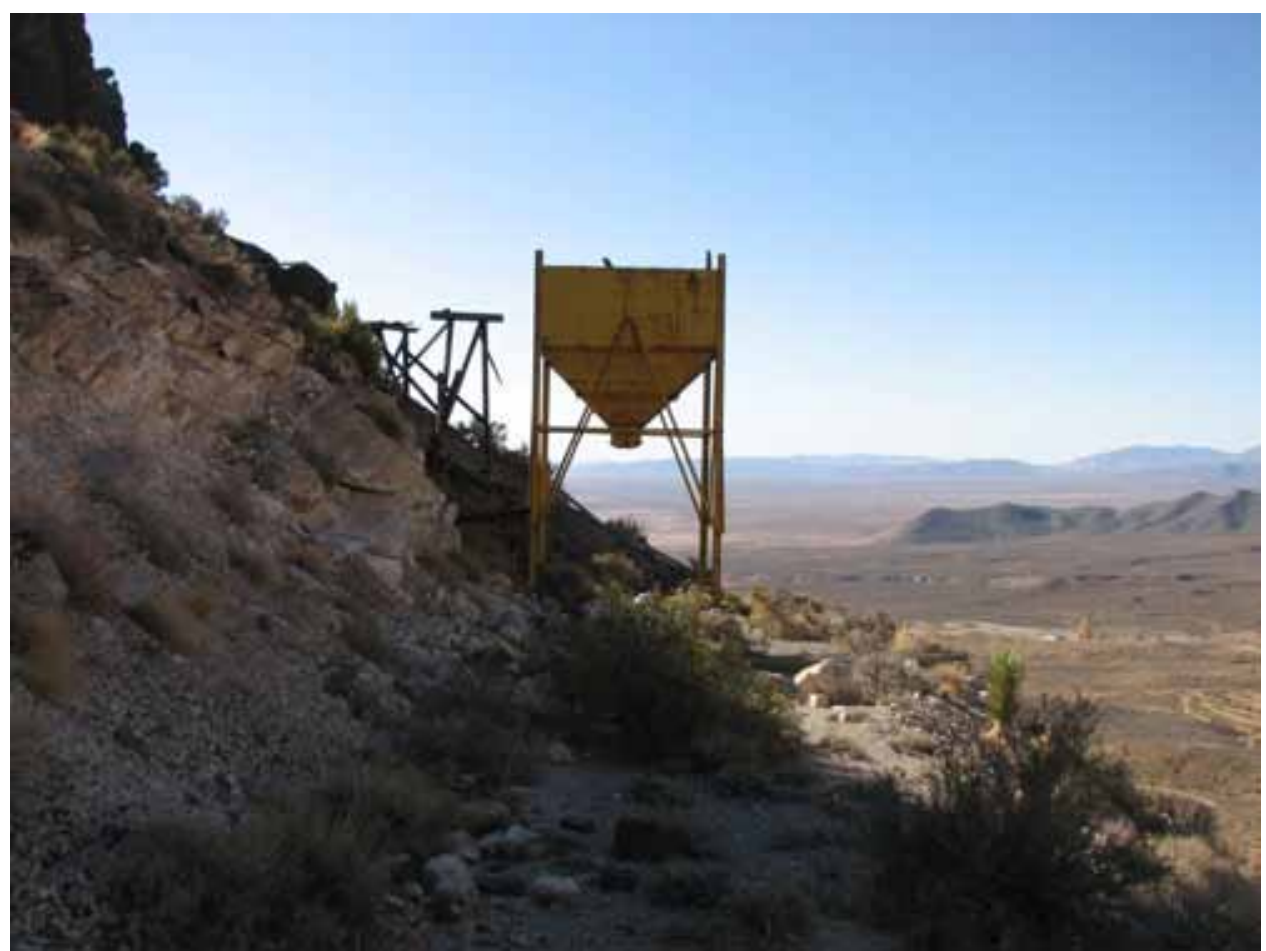

Photograph 3: CAS 15-01-05, Sampling at Original Tank Location, 10/20/2008

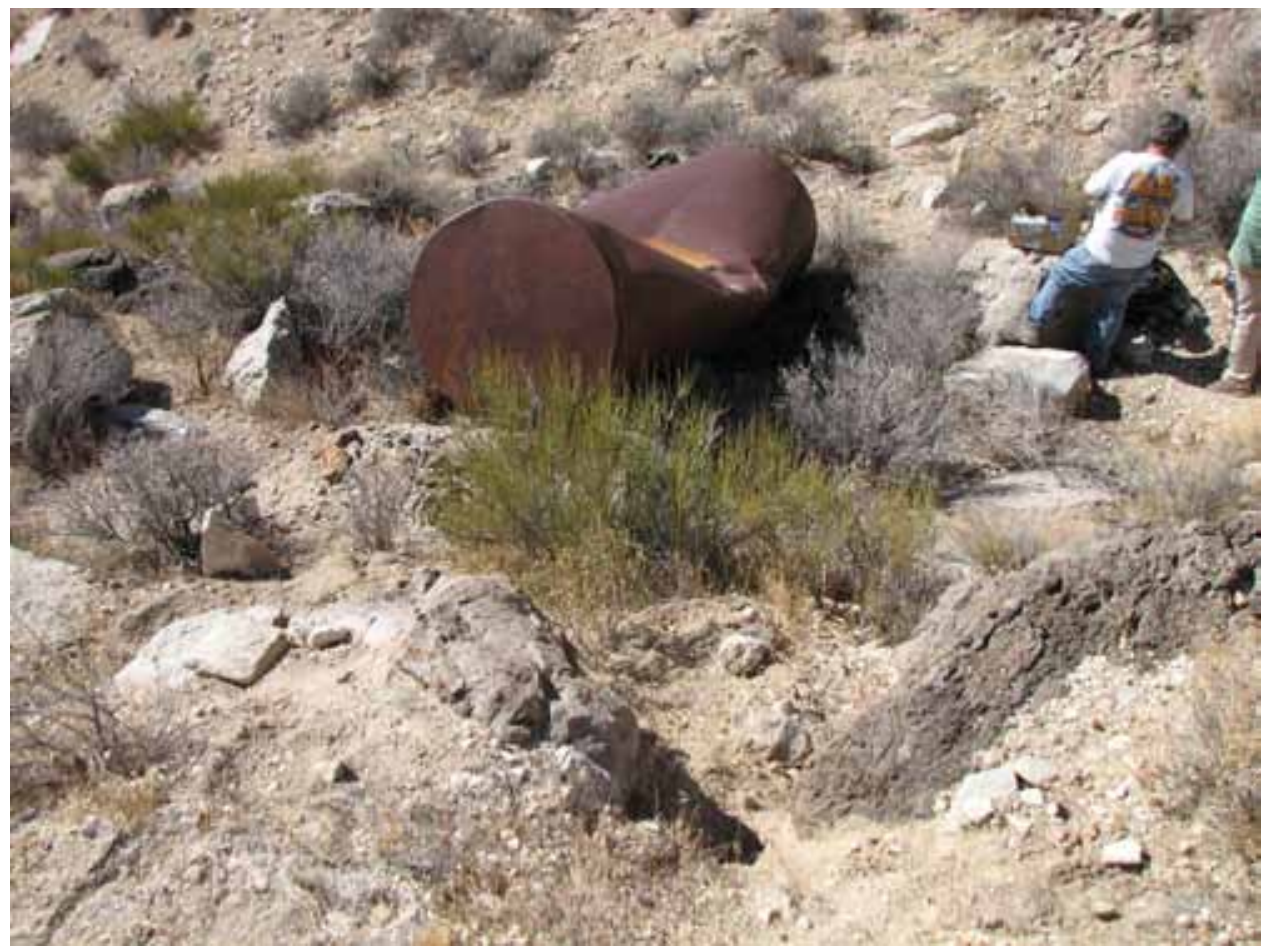

Photograph 4: CAS 15-01-05, Sampling at Current Tank Location, 10/20/2008 


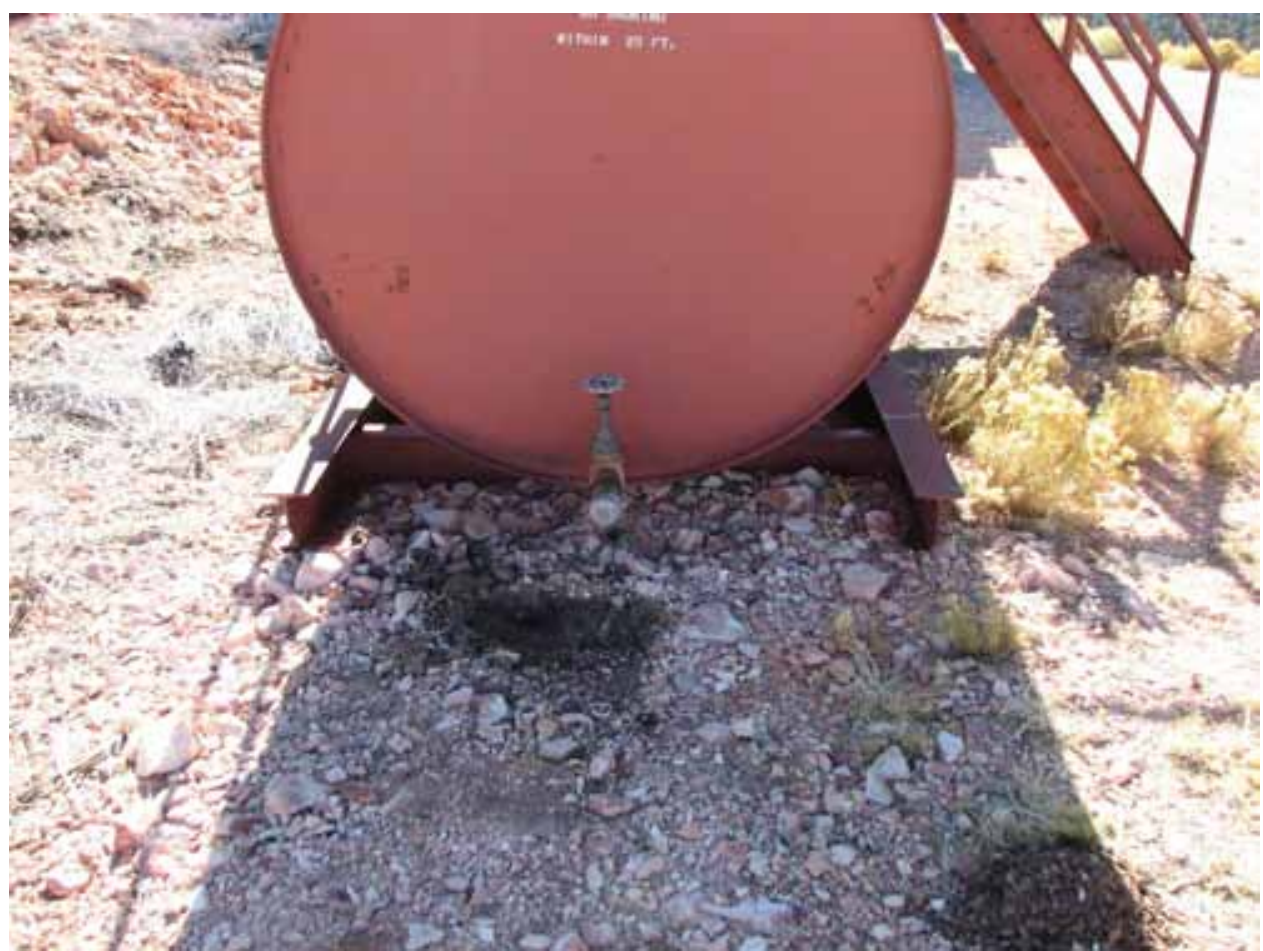

Photograph 5: CAS 29-01-01, Sampling beneath Tank Spigot, 10/21/2008

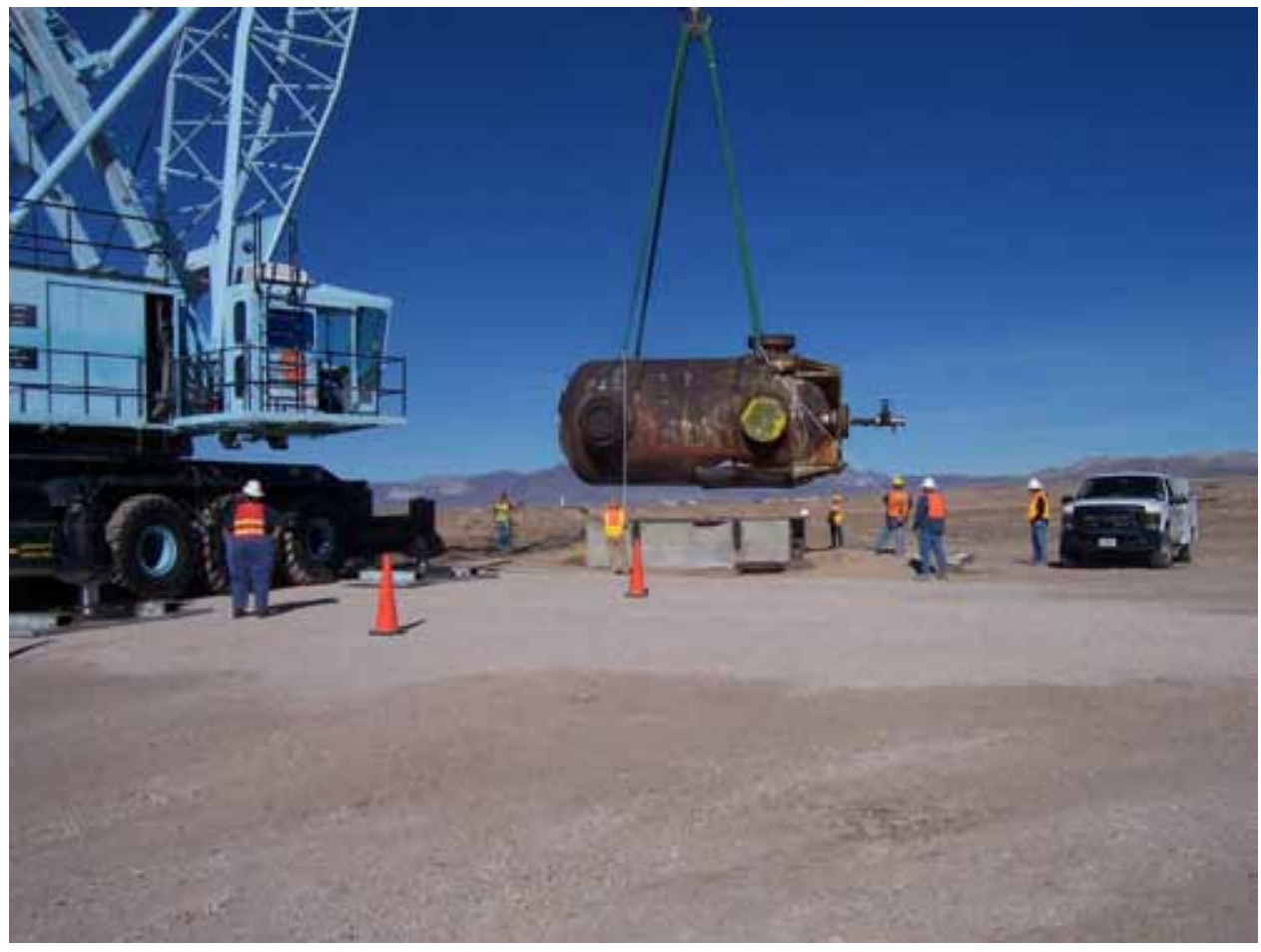

Photograph 6: CAS 03-01-03, Removal of Tank using Crane, 12/01/2008 


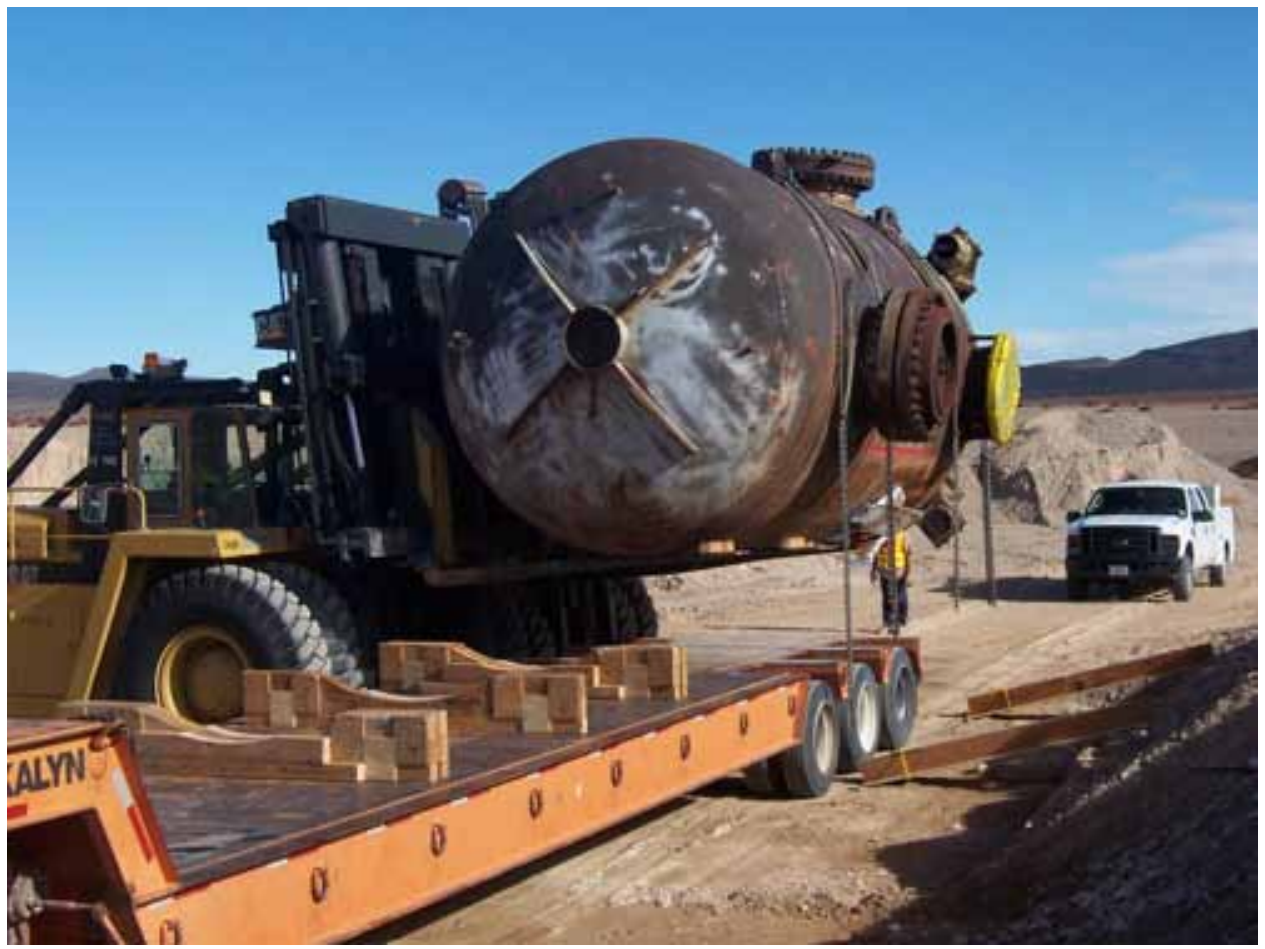

Photograph 7: CAS 03-01-03, Disposal of Tank at Landfill, 12/02/2008

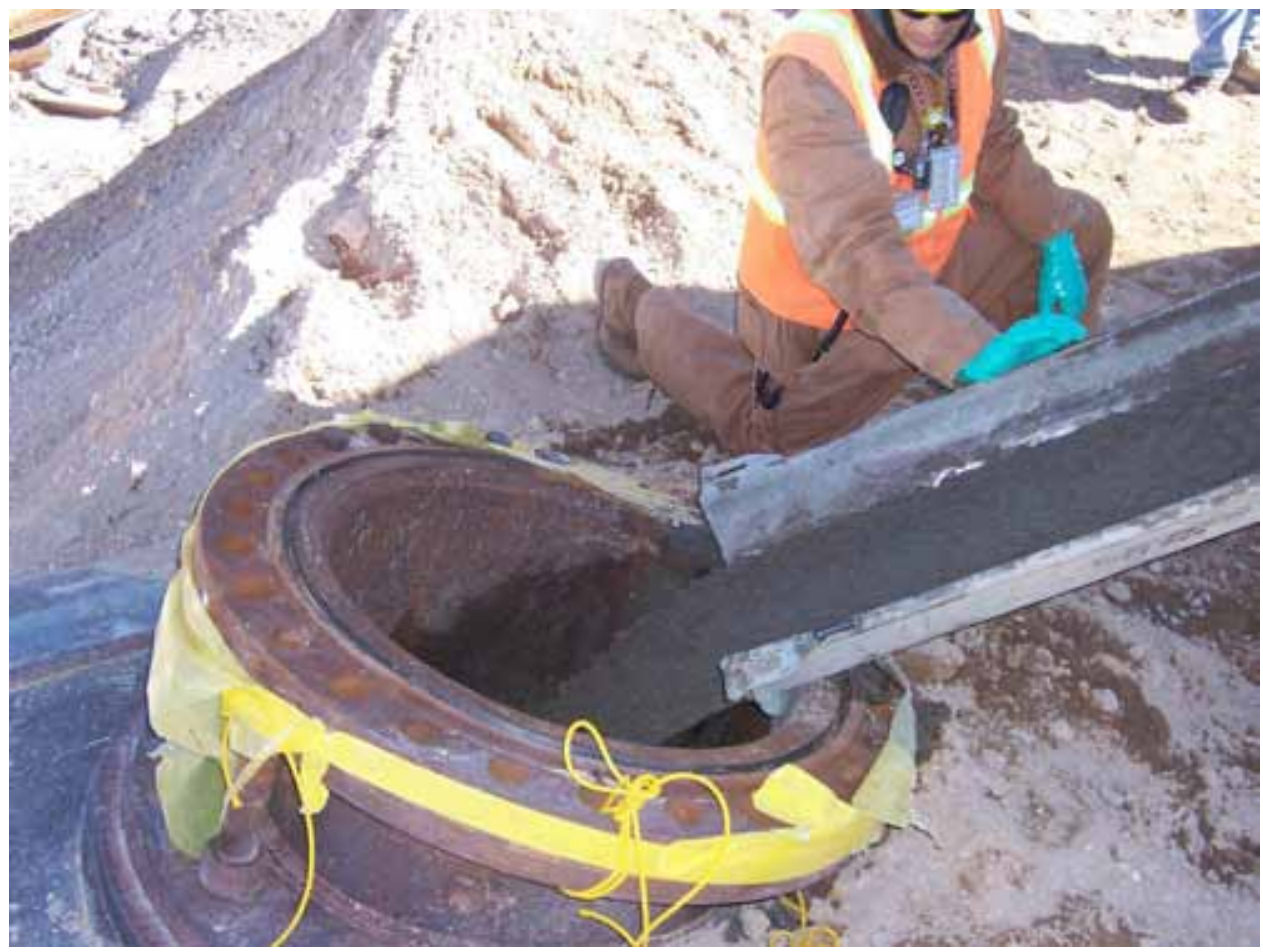

Photograph 8: CAS 03-01-03, Grouting Tank at Landfill, 12/10/2008 


\section{APPENDIX E}

\section{MEMORANDUM OF HISTORICAL SIGNIFICANCE OF TANK AT CORRECTIVE ACTION SITE 15-01-05}


CAU 134 Closure Report

Section: Appendix E

Revision: 0

Date: June 2009

THIS PAGE INTENTIONALLY LEFT BLANK 


\section{SCIENCE • ENYIRONMENT • SOLUTIONS}

June 8, 2009

Memo to: Linda Cohn, Cultural Resources Program Manager, NNSA/NSO

From: Colleen M. Beck, Ph.D., Cultural Resources Projects Manager, DRI

Subject: Historical Significance of the Fuel or Water Tank at CAU 134, CAS 15-01-05

Under the Industrial Sites Program, the fuel or water tank at CAU 134, CAS 15-01-5 was identified for removal under proposed cleanup activities. However, this tank is one of the historic objects at a historic mining site that was determined eligible to the National Register of Historic Places through consultation between the NNSA/NSO and the Nevada State Historic Preservation Office. DRI recommends that the tank be left in place because it is part of a significant historic site and removal of the tank would require mitigation activities in consultation with the Nevada State Historic Preservation Office. A brief synopsis of the site is provided below.

This site contains two distinct historic mining occupations. The first is the earliest archaeological evidence of mining on the Nevada Test Site and the second is the last mining operation allowed there. The initial occupation contains the earliest historic artifacts found at the Nevada Test Site, such as food cans that date to the last decades of the $1800 \mathrm{~s}$, and an old adit. There also are other artifacts there that show the area was used by miners until at least 1908. Then in 1937, the Climax Mine was developed for the extraction of tungsten ore. The mine was operated sporadically until 1957, when the Atomic Energy Commission terminated the co-use agreement with the mine's operators. Artifacts from this era also are present at the site. The fuel or water tank dates to this time and originally stood on the muck pile outside the adit. This tank and some other mining materials are now resting on the slope below.

This archaeological site is within the Oak Springs Mining District, established in the 1880s, following initial mining activities in the area in the late 1860s and 1870s. Mining claims were registered for gold, silver, tungsten, and chrysocolla. It is not known which claims were associated with the adit and artifacts from the late nineteenth and early twentieth centuries. However, these artifacts are the oldest historic artifacts at the Nevada Test Site. The Climax Mine and the artifacts associated with this mining operation are important to the history of the region because the Climax Mine was the last ore mine operated at the Nevada Test Site.

2215 Raggio Parkway, Reno, Nevada 89512-1095 Phone (775) 673-7300 Fax (775) 673-7397
755 E. Flamingo Road, Las Vegas, Nevada 89119-7363 Phone (702) 862-5400 Fax (702) 862-5496 
CAU 134 Closure Report

Section: Appendix E

Revision: 0

Date: June 2009

THIS PAGE INTENTIONALLY LEFT BLANK 


\section{APPENDIX F}

\section{NEVADA DIVISION OF ENVIRONMENTAL PROTECTION COMMENT RESPONSE FORM}


CAU 134 Closure Report

Section: Appendix F

Revision: 0

Date: June 2009

THIS PAGE INTENTIONALLY LEFT BLANK 
Document Title: Draft Closure Report for Corrective Action Unit 134: Aboveground Storage Tanks, Nevada Test Site, Nevada

\section{Revision Number: 0}

Responsible NNSA/NSO ERP Federal Sub-Project Director: Kevin Cabble
Document Date: April 2009

Author/Organization: NSTec

Reviewer/Organization/Phone: Jeff MacDougall/NDEP/486-2850 ext 233

Review Criteria: Full

\begin{tabular}{|c|c|c|c|c|c|c|}
\hline $\begin{array}{c}\text { Comment } \\
\text { No. } \\
\end{array}$ & Comment & \multicolumn{5}{|c|}{ Comment Response } \\
\hline 1 & $\begin{array}{l}\text { Section 2.1.2.4, Page 8: Based on the lateral and vertical } \\
\text { extent of contamination, as defined in this section, and } \\
\text { considering the TPH concentrations (above } 100 \mathrm{mg} / \mathrm{kg} \text { ) } \\
\text { identified in the soil samples at this site, provide an } \\
\text { estimated volume of soil that is contaminated at the site. }\end{array}$ & \multicolumn{5}{|c|}{$\begin{array}{l}\text { The volume of soil exceeding the action level for TPH is less than approximately } 100 \text { cubic feet. } \\
\text { A use restriction is no longer required at CAS 29-01-01, and all references to a use restriction at this } \\
\text { site have been removed from the document. } \\
\text { The analytical laboratory originally reported detection limits for benzo(a)anthracene and } \\
\text { benzo(a)pyrene that were greater than the action levels of } 2.1 \text { milligrams per kilogram (mg/kg) and } \\
0.21 \mathrm{mg} / \mathrm{kg} \text {, respectively. However, these reported detection limits are the reporting limits (RLs), not } \\
\text { the minimum detectable concentrations (MDCs). The MDCs for benzo(a)anthracene and } \\
\text { benzo(a)pyrene were } 0.05 \mathrm{mg} / \mathrm{kg} \text { and } 0.2 \mathrm{mg} / \mathrm{kg} \text {, respectively, which are below the action levels. } \\
\text { These constituents were not detected above the MDCs. } \\
\text { The laboratory’s list of MDCs has been added to Appendix B, Sample Analytical Results. The } \\
\text { following table lists the action levels, MDCs, and RLs in mg/kg for benzo(a)anthracene and } \\
\text { benzo(a)pyrene. }\end{array}$} \\
\hline & & Constituent & Action Level & $\begin{array}{c}\text { Minimum } \\
\text { Detectable } \\
\text { Concentration }\end{array}$ & $\begin{array}{l}\text { Reporting } \\
\text { Limit }\end{array}$ & Result \\
\hline & & benzo(a)anthracene & 2.1 & 0.05 & 3.7 & $<$ MDC \\
\hline & & benzo(a)pyrene & 0.21 & 0.2 & 1.8 & $<$ MDC \\
\hline
\end{tabular}


CAU 134 Closure Report

Section: Appendix F

Revision: 0

Date: June 2009

THIS PAGE INTENTIONALLY LEFT BLANK 
CAU 134 Closure Report

Section: Library Distribution List

Revision: 0

Date: June 2009

\section{LIBRARY DISTRIBUTION LIST}


CAU 134 Closure Report

Section: Library Distribution List

Revision: 0

Date: June 2009

THIS PAGE INTENTIONALLY LEFT BLANK 


\section{LIBRARY DISTRIBUTION LIST}

U.S. Department of Energy

National Nuclear Security Administration

Nevada Site Office

Technical Library

P.O. Box 98518, M/S 505

Las Vegas, NV 89193-8518

U.S. Department of Energy

Office of Scientific and Technical Information

P.O. Box 62

Oak Ridge, TN 37831-0062

Southern Nevada Public Reading Facility

c/o Nuclear Testing Archive

P.O. Box 98521, M/S 400

Las Vegas, NV 89193-8521

Manager, Northern Nevada FFACO

Public Reading Facility

c/o Nevada State Library \& Archives

Carson City, NV 89701-4285
1 (Uncontrolled, electronic copy)

1 (Uncontrolled, electronic copy)

2 (Uncontrolled, electronic copies)

1 (Uncontrolled, electronic copy) 
CAU 134 Closure Report

Section: Library Distribution List

Revision: 0

Date: June 2009

THIS PAGE INTENTIONALLY LEFT BLANK 